WHOI -73-58

SEDIMENTARY PROCESSES ON THE CONTINENTAL SLOPE

OFF NEW ENGLAND

By

Joseph Chad MacIivaine

WOODS HOLE OCEANOGRAPHIC INSTITUTION

Woods Hole, Massachusetts 02543

September 1973

TECHNICAL REPORT

Prepared for the Office of Naval Research

under Contract N00014-66-C0241; NR 083-004.

Reproduction in whole or in part is permitted

for any purpose of the United States Govermment. In citing this manuscript in a bibliography, the reference should be followed by the phrase: UNPUBLISHED MANUSCRIPT.

Approved for public release, distribution unlimited.

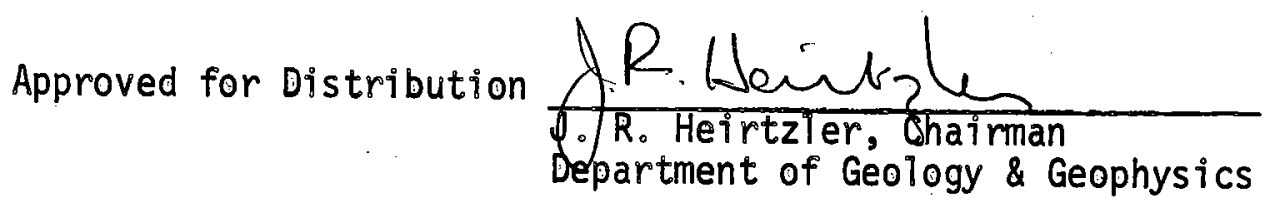


SEDIMENTARY PROCESSES ON THE

CONTINENTAL SLOPE OFF NEW ENGLAND

by

JOSEPH MACILVAINE

B.A. The University of California at Berkeley (1969)

SUBMITTED IN PARTIAL FULFILIMENT OF THE REQUIREMENTS FOR THE DEGREE OF DOCTOR OF PHILOSOPHY

at the

MASSACHUSETTS INSTITUTE OF TECHNOLOGY

and the

WOODS HOLE OCEANOGRAPHIC INSTITUTION

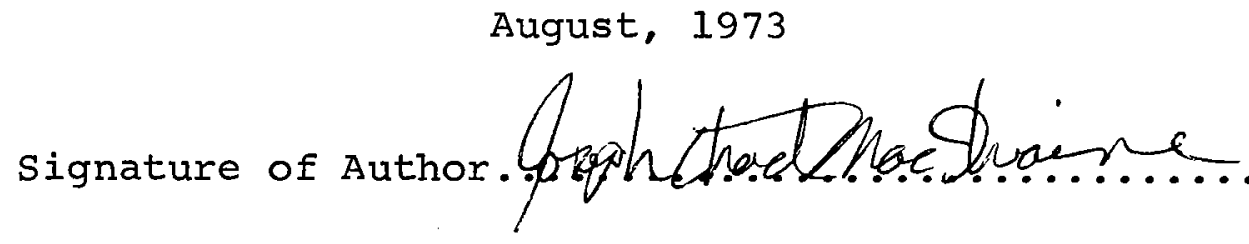

Joint Program in Oceanography, Massachusetts Institute of Technology - Woods Hole Oceanographic Institution, and Department of Earth and Planetary Sciences, and Department of Meteorology, Massachusetts Institute of Technology, August, 1973

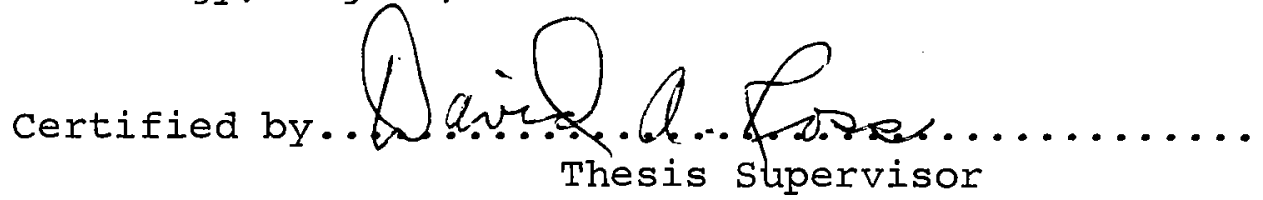

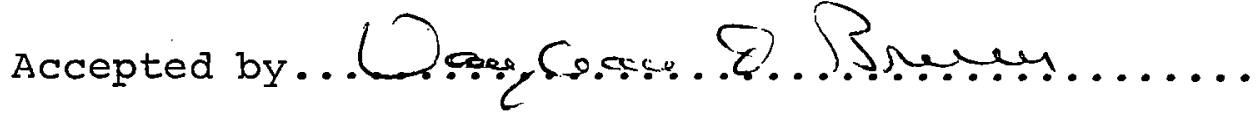

Chairman, Joint Oceanography Committee in the Earth Sciences, Massachusetts Institute of Technology - Woods Hole Oceanographic Institution. 


\section{SEDIMENTARY PROCESSES ON THE \\ CONTINENTAL SLOPE OFF NEW ENGLAND}

Joseph MacIlvaine

Submitted to the Massachusetts Institute of TechnologyWoods Hole Oceanographic Institution Joint Program in Oceanography on August 9, 1973, in partial fulfillment of the requirements for the degree of Doctor of Philosophy.

\section{ABS TRACT}

A detailed study of a small $\left(5000 \mathrm{~km}^{2}\right)$ area of the continental slope south of Cape Cod, Massachusetts, was conducted. Bathymetry, $3.5 \mathrm{kHz}$ profiles, seismic profiles, suspended sediment analysis, bottom photographs, television, laboratory flume experiments, studies of surface sediments, and piston cores were combined to form the basis for understanding the sedimentary processes which control transportation, deposition, and erosion of sediments, and the geomorphic features of the continental slope.

Gravitational processes (slumping, creep, and turbidity currents) are apparently the most effective erosional processes on the continental slope. Massive large-scale failure occurs where the slope steepens from a gradient of $1.5^{\circ}$ to $7.6^{\circ}$. producing scarps hundreds of meters in height. Upslope propagation of slumping on the upper continental slope has formed steep-sided gullies with layers of disturbed residual material and hummocky floors. On the steep lower continental slope small slump scars on the order of $100 \mathrm{~m}$ in horizontal extent and several meters high are common. Material removed by slumping is emplaced at the foot of the continental slope as intact and disrupted blocks 1 to $100 \mathrm{~m}$ thick. Turbidity currents generated by slumping have apparently eroded V-shaped gullies in the lower continental slope.

Bottom currents are most influential at the shelfbreak, where they produce sorting of surface sediments and suspension of fine material by erosion of the bottom. Internal waves may be a significant source of high velocity bottom currents and turbulence. Laboratory flume experiments and observation of the bottom indicate that the 
sediments of most of the continental slope are not normally affected by bottom currents. Sediments at the foot of the continental slope on the upper continental rise are reworked by bottom currents.

Biological activity causes both roughening and smoothing of the sediment surface. Tracking of the bottom produces small-scale roughness, and reworking of the bottom reduces larger roughness elements. Biological production of fibrous structures helps render the sediment surface extremely resistant to erosion by bottom currents. Biological erosion of rock outcrops produces rubble slopes locally at the bases of scarps.

Conditions have varied markedly during the Pleistocene and Holocene. During glacial periods rapid deposition increased the activity of gravitational processes, while during interglacial periods of slow deposition biological and hydrodynamic processes became relatively more important. 


\section{ACKNOWLEDGEMENTS}

This study was made possible by the unselfish help of many individuals. In particular I thank Dr. D.A. Ross for his continuous support and guidance. Drs. K.O. Emery and J.B. Southard served on my thesis committee, and added valuable insights. Dr. G.T. Rowe was especially helpful in providing me with the chance to dive on the continental slope in DSRV ALVIN.

The success of this study was in large part due to the efforts of the officers and crews of the research vessels GOSNOLD, ATLANTIS II, LULU, and ALCOA SEAPROBE, and the many individuals who participated on the cruises to the study area. In particular, Dr. D.A. Ross directed operations on ATLANTIS II cruise 72, and Mr. Scott Briggs aided in suspended sediment analysis.

This work was supported through several grants to the Woods Hole Oceanographic Institution. The Union Oil Company of California Foundation supported my first three years as a graduate student, and my last year, plus ship and laboratory expenses were supported by the office of Naval Research contract CO-N-00014-66-0241. Ocean Search Incorporated supplied ship time for two cruises on the 
ALCOA SEAPROBE, and the Ocean Industries Program of the Woods Hole Oceanographic Institution provided funds for shipboard operations on these cruises.

Drs. D.A. Ross, J.B. Southard, and K.O. Emery read the manuscript and made valuable suggestions for improvements. 
TABLE OF CONTENTS

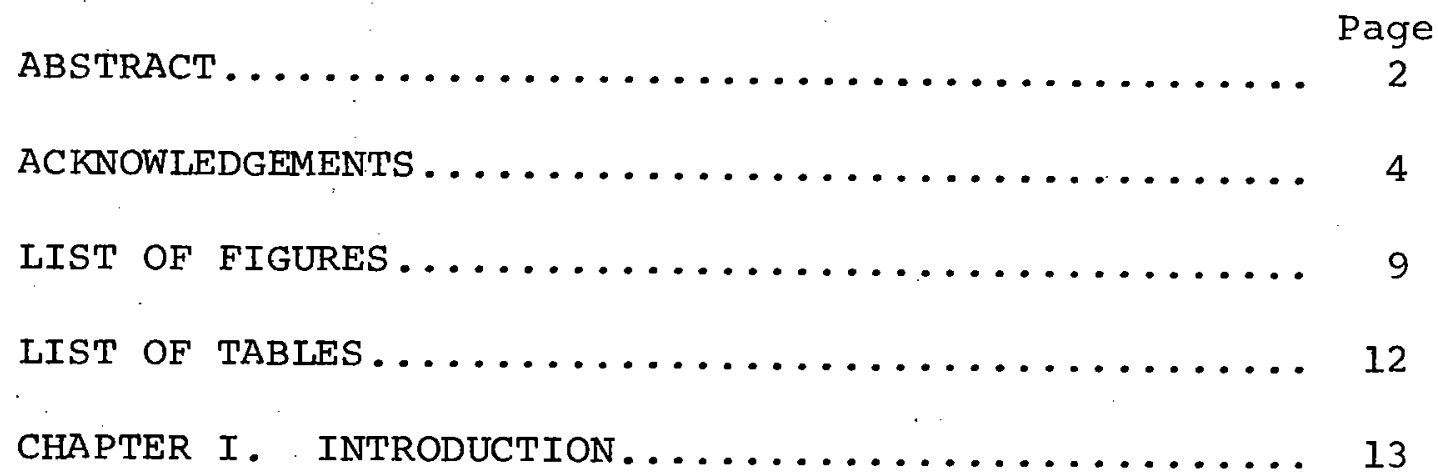

Statement of the problem............... 13

Geological setting................... 14

Previous work....................... 19

Present work....................... 20

CHAPTER II. DATA..................... 23

Bathymetry....................... 23

$3.5 \mathrm{kHz}$ echosounding................. 31

Seismic reflection profiles............. 35

Suspended sediments.................. 67

The sediment-water interface........... 75

Bottom photographs, television,

and direct observation........... 75

Laboratory flume experiments.......... 108 
Table of contents continued

Page

Characteristics of surface sediments......... 114

Introduction.................. 114

Size Analysis.................... 114

Composition of the sand fraction........ 122

Composition of the silt and clay

fractions.................. 131

Core studies..................... 136

Introduction.................. 136

Foraminifera and rates of deposition..... 137

Texture and shear strength........... 147

Mineralogy.................... 154

CHAPTER III. SUMMARY OF DATA................ 163

CHAPTER IV. DISCUSSION OF RESULTS............ 173

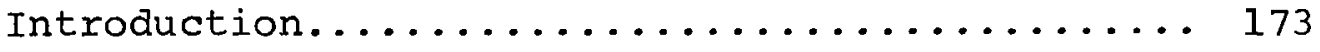

Gravitational processes................ 174

Hydrodynamic processes................ 183

Biological processes.................. 187

Net effects of sedimentary processes

during the Pleistocene and Holocene...... 192 
Table of contents continued

Early Pleistocene and Pre-Pleistocene

conditions...................... 196

CHAPTER V............................. 198

Summary and Conclusions................. 198

REFERENCES ............................. 201

BIOGRAPHY ........................... 211 


\section{LIST OF FIGURES}

Figure

Page

1. Position of the study area.

2. Bathymetric control.

3. Bathymetry of the study area.

4. Bathymetric profiles of the continental slope.

5. Positions of $3.5 \mathrm{kHz}$ profiles.

6. Three-dimensional drawing of $3.5 \mathrm{kHz}$ profiles.

7. Portion of $3.5 \mathrm{kHz}$ profile near the shelf-break.

8. Transition of shelf break to upper continental slope.

9. Portion of $3.5 \mathrm{kHz}$ profile from the upper continental slope.

10. Steep-sided gullies on the upper continental slope.

11. Extension of erosional feature over a large area near the transition to lower continental slope.

12. V-shaped gully on the upper continental slope.

13. Seaward-facing scarp on the upper continental slope.

14. Gullies on the steep lower continental slope.

15. Portion of $3.5 \mathrm{kHz}$ profile of the upper continental rise.

16. Positions of seismic profiles taken within the study area.

17. North-south seismic reflection profiles. 
Figure

Page

18. Three-dimensional drawing of seismic profiles.

19. Positions of suspended sediment stations.

20. Concentrations of suspended sediments.

21. Bottom photograph at $120 \mathrm{~m}$ water depth.

22. Positions of bottom photographic stations.

23. Bottom photograph at $140 \mathrm{~m}$ water depth.

24. Bottom photograph at $190 \mathrm{~m}$ water depth.

25. Bottom photograph at $290 \mathrm{~m}$ water depth.

26. Bottom photograph at $400 \mathrm{~m}$ water depth.

27. Bottom photograph at $1175 \mathrm{~m}$ water depth.

28. Bottom photograph at $1790 \mathrm{~m}$ water depth.

29. Bottom photograph at $900 \mathrm{~m}$ water depth.

30. Composite photograph of rock outcrop.

31. Scarp on the lower continental slope.

32. Drawing of slump scar on the lower continental slope.

33. Photograph at $2160 \mathrm{~m}$ water depth.

34. Photograph of cobble patch at $2160 \mathrm{~m}$ water depth.

35. Positions of sediment samples.

36. Textural composition of surface samples.

37. Plots of texture versus depth. 
Figure

38. Composition of the sand fraction.

39. Composition of the carbonate fraction.

40. Heavy-mineral composition of the surface samples.

41. Composition of the silt fraction.

42. Composition of the clay fraction.

43. Trends of foraminiferal faunas with depth in cores.

44. Textural composition of cores.

45. Shear strength of cores.

46. Composition of the sand fraction of cores.

47. Composition of the silt fraction.

48. Ratios of clay minerals in cores.

49. Summary of physiography and shallow structure.

50. Summary of suspended sediments, character of the sediment surface, and epibenthic fauna.

51. Summary of the characteristics of Pleistocene and Holocene sediments. 


\section{LIST OF TABLES}

Table

Page

1. Field work conducted in the study area.

2. Experimental erosion of "undisturbed" and resedimented continental slope sediments.

3. Analysis of surface sediments.

4. Species of Foraminifera used to differentiate between glacial and interglacial conditions. 
CHAPTER I

INTRODUCTION

\section{STATEMENT OF THE PROBLEM}

Two basic incentives towards understanding the sedimentary environment of the continental slope are: 1) The slope is a major physiographic feature of the ocean floor, and may be characterized by a combination of sedimentary processes unlike that of any other province in the deep ocean; 2) The continental slope occupies a prominent position in the worldwide sedimentary regime. Although the slope environment comprises only a small fraction of the ocean floor (less than 9\%, based on Menard and Smith, 1966), all detrital material (excepting windborn material) entering the deep sea must pass over it. The continental slope is thus an important area for study, both in itself and as part of the larger oceanic sedimentary system. The objective of this work is to determine:

a) which sedimentary processes are active on the continental slope;

b) how these processes combine to control deposition and erosion and thus the physiography and structure of the continental slope and the characteristics of continental 
slope deposits;

c) the ways in which processes acting on the continental slope have responded to changes in environment during the Pleistocene and Holocene.

A detailed study of a small portion of the continental slope off New England was made. The study area (Fig. 1) was small enough to allow detailed sampling and surveying by a wide variety of techniques, but large enough to include a submarine canyon and a representative section of open continental slope. Along the continental margin of the northeastern United states the continental slope is most easily defined as that section of ocean floor lying between the flat continental shelf and the gently sloping continental rise, and having a gradient exceeding 1:40 (Heezen, Tharp, and Ewing, 1959). GEOLOGICAL SETTING

The continental slope off New England represents the edge of the Atlantic Coastal Plain province of North America. Paleozoic metamorphic and crystalline rocks are overlain by a seaward-thickening section of cretaceous and Cenozoic sediments. The basement off much of eastern North America has the form of basins separated by ridges which 
Figure 1. Position of detailed study area (shaded) with respect to major features of the continental margin off Eastern North America. 


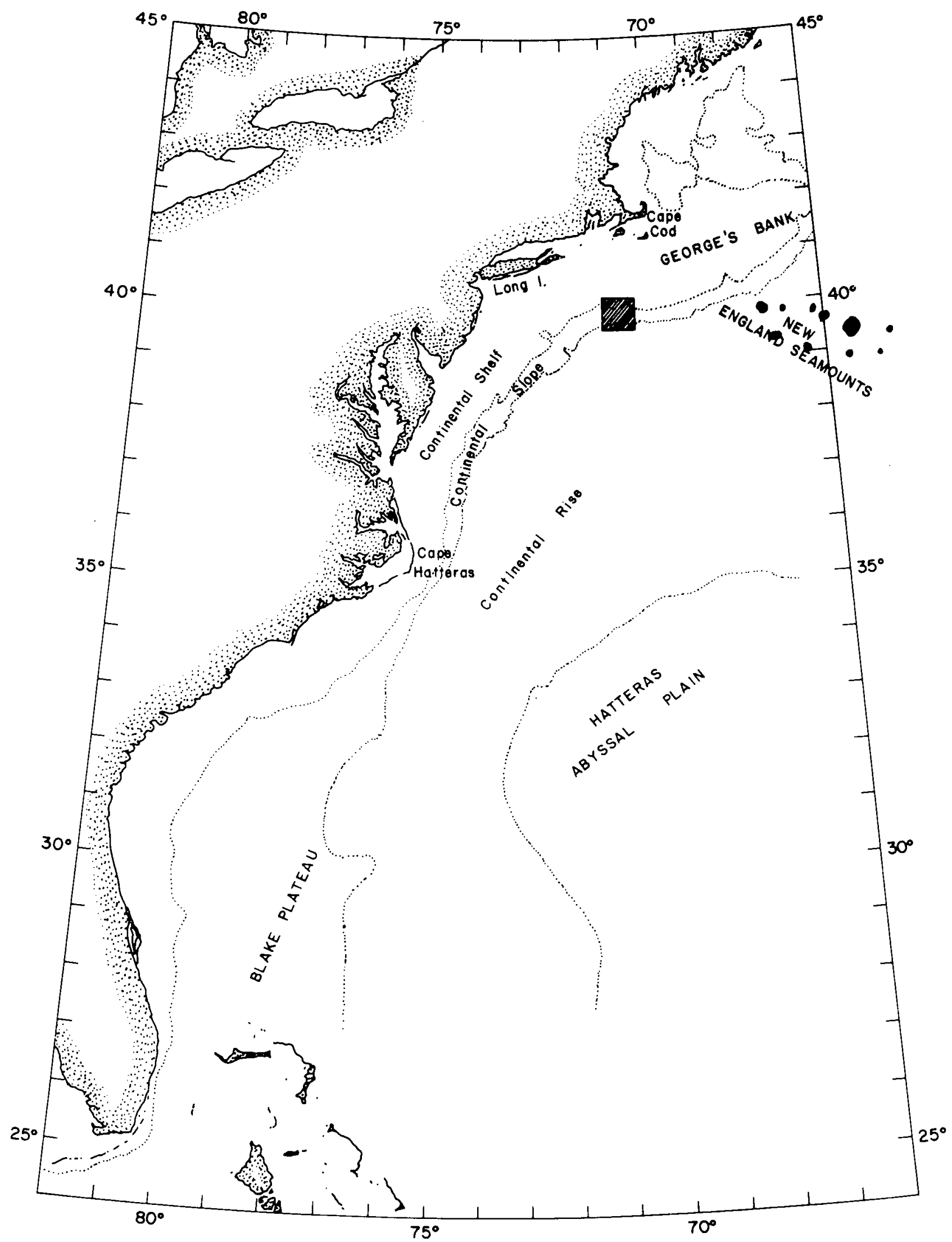

Figure 1. 
trend generally parallel to the trend of the continental slope. The basin-ridge structure is offset by the rightlateral Kelvin Fault, which apparently cuts across the continental margin from near New York and continues seaward along the New England Seamount Chain (Drake and others, 1968).

Cretaceous and Cenozoic shallow-marine sediments of several kilometers thickness lie atop the Paleozoic basement. The upper portions of this sequence thicken and dip seaward from exposures in New Jersey and on Martha's Vineyard and crop out locally on the continental slope (Stetson, 1949; Murray, 1961; Northrop and Heezen, 1951; Gibson and others, 1968).

The continental rise is a thick prism of sediments lying at the base of the continental slope: Horizon $A$, a prominent reflection sequence of upper Cretaceous to Eocene age present throughout much of the western North Atlantic ocean (Ewing and others, 1969), underlies the continental rise. Horizon A forms a flat, nearly horizontal surface upon which up to three kilometers of sediment having weak and distorted internal reflectors has been deposited (Emery and others, 1971). 
The continental slope thus lies between the continental shelf, which has been gradually built upwards to compensate for downwarping and seaward tilting, and the continental rise, which has been deposited at the base of the continental slope, burying the lower portions of the continental slope.

During the late Pliocene and Pleistocene, continental glaciation lowered sea level, exposing much of the continental shelf. The minimum extent of Pleistocene glaciers is marked by terminal or recessional moraines on Long Island, Block Island, Martha's Vineyard, and Nantucket, but glaciers may have reached nearly to the shelf edge south of Martha's Vineyard and Block Island (Emery and Uchupi, 1972). On Georges Bank at least five erosional surfaces are recognized in the upper 100 meters of sediment (Knott and Hoskins, 1968). Five deltaic sequences separated by well developed unconformities have been recognized off New Jersey and New York (Ewing and others, 1963; Knott and Hoskins, 1968)

The surface sediments of the continental margin from Long Island to Georges Bank range from the sands of the continental shelf to the sandy silty clays of the continen- 
tal rise. The continental shelf sands are generally regarded as relict glacial and fluvial deposits which were reworked by the last transgression of the shoreline across the shelf, and which have been little altered since that time except for the gradual addition of calcareous skeletal material (Garrison and McMaster, 1966; Milliman and others, 1972). An anomalous area of fine-grained sediment occupies the outer shelf south of Cape cod. Its origin remains in doubt, but most workers agree that it is post-transgressional in age (Stetson, 1936; McMaster and Garrison, 1966; Trumbu11, 1972).

The continental slope is blanketed by a nearly continuous layer of Pleistocene and Holocene sediments ranging in texture from sands to silty clays, but generally falling in the clayey silt and sandy silt classes of Shepard (1954). This general decrease in grain size from the shelf onto the slope continues onto the continental rise, where the bulk of Pleistocene and Recent deposits are silty clays interbedded with sharply defined layers of sand (Ericson and others, 1961).

PREVIOUS WORK

Most of the previous work done in the vicinity of this 
study area has been in the form of large-scale studies of a regional nature (good examples are: Uchupi and Emery, 1967; Hoskins, 1967; Milliman and others, 1972).

More detailed studies within the area of this investigation include investigations of short cores for sediment characteristics (Stetson, 1949) and Foraminifera faunas (Phleger, 1939, 1942); description of Eocene rocks recovered from the continental slope (Stetson, 1949; Northrop and Heezen, 1951); a detailed seismic-reflection survey of a large-scale slump feature on the lower portions of the continental slope (Uchupi, 1967); several bottom photographs (Owen and Emery, 1967); and a detailed survey of a small portion of the continental slope adjacent to Alvin Canyon by submersible (Emery and Ross, 1968). PRESENT WORK

The present study is based primarily on data and samples gathered on cruises of the Woods Hole Oceanographic Institution during 1971 and 1972 (Table 1). These included operations aboard R/V GOSNOLD; R/V ATLANTIS II; two cruises aboard ALCOA SEAPROBE utilizing an instrument pod equiped with closed circuit television, bottom cameras, and side looking sonar; and dives in the research submersible ALVIN 


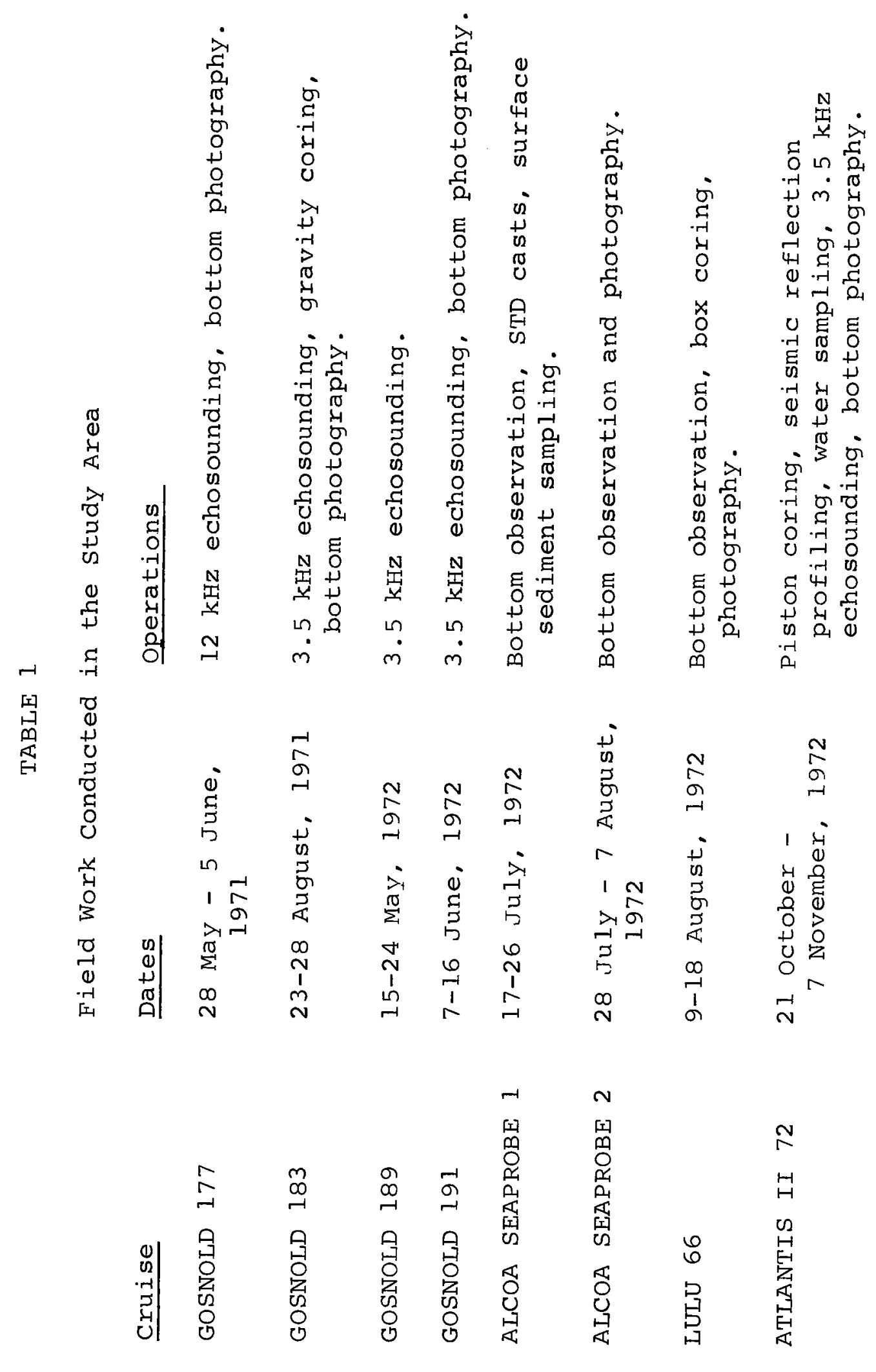


for direct observation of the bottom on the lower continental slope.

In addition to the field work, samples which were collected during the cooperative U. S. Geological Survey Woods Hole Oceanographic Institution continental margin study of 1962-1970 were analyzed and incorporated in this study •

Laboratory investigations included analysis of sediment samples and experimental erosion of "undisturbed" continental-slope sediment. 


\section{CHAPTER II}

DATA

\section{BATHYMETRY}

Echosoundings were made on five cruises to the study area (Fig. 2). The resolution was limited by the precision of navigation and the width of the sound source beam. Navigation was based primarily on Loran-A readings taken at an average interval of twenty minutes. Loran-A positions are considered to be reproducible to about $1 \mathrm{~km}$ at best. On the steeper portions of the continental slope a $1 \mathrm{~km}$ offset could produce a depth change of 200 meters. Actual line crossings had an average discrepancy of 20 meters on the lower continental slope; the largest discrepancy observed was 71 meters, suggesting that the relative positions within the study area are accurate to closer than 1 $\mathrm{km}$.

The second limit to detail in the bathymetric survey was the wide beam of the sound sources (a $60^{\circ}$ cone), which in areas of deep water and high relief produce hyperbolic reflections rather than a true profile of the bottom. In 1500 meters water depth, reflections from a circular area with a diameter of more than $1 \mathrm{~km}$ are received, and steep- 
Figure 2. Bathymetric control. Points indicate the soundings read from analog depth recordings taken during the cruises in Table 1 which were used to construct the bathymetric base chart for this study. 


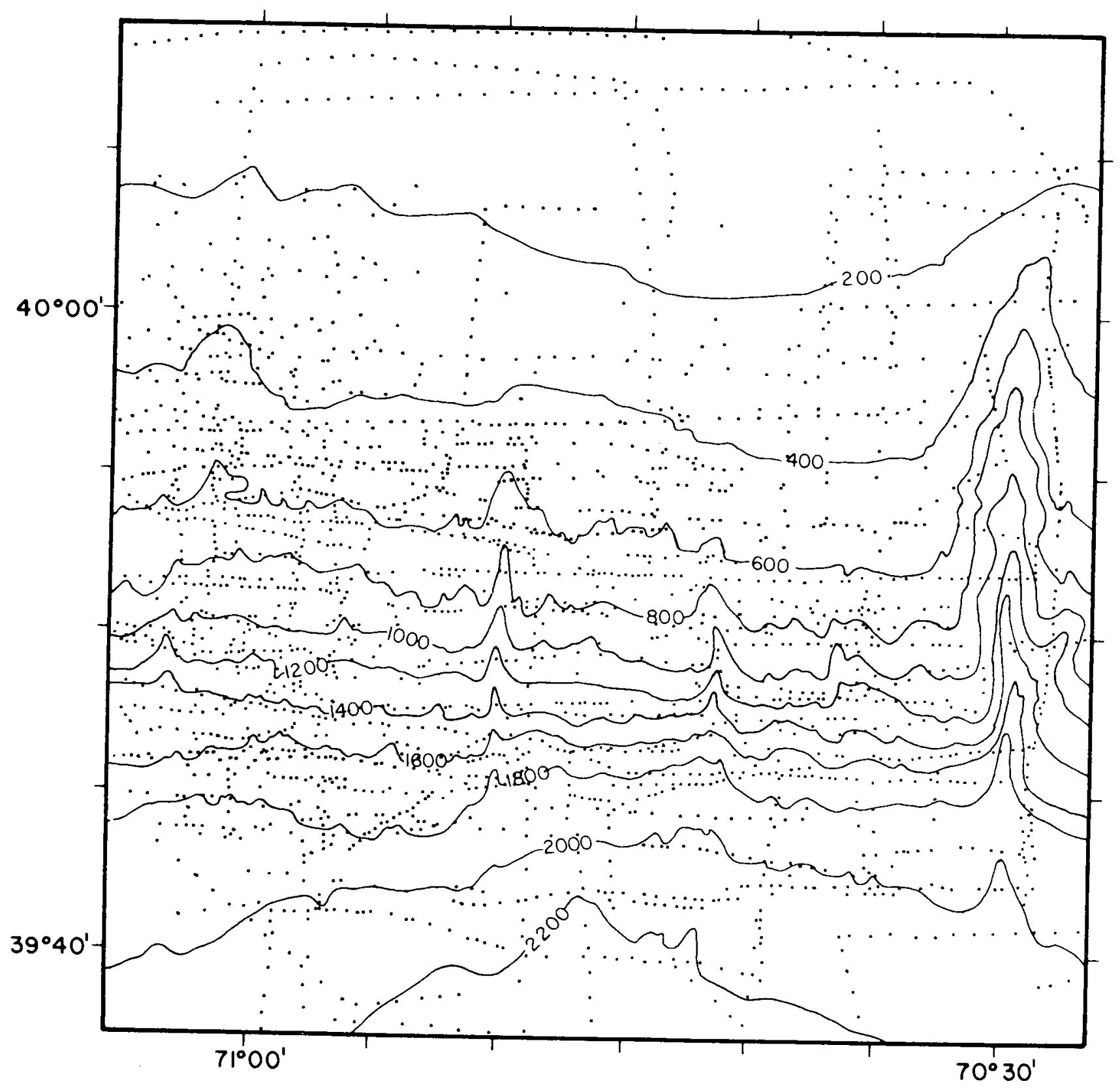

Figure 2. 
sided features smaller than about $1 / 2 \mathrm{~km}$ are not properly resolved. Within these limitations, Figure 3 is an accurate representation of the shape of the continental slope surface.

The most striking topographic feature in this area is Alvin Submarine Canyon at 70³0' (Emery and Ross, 1968). The canyon is steep-sided, with average slopes of $10-15^{\circ}$ on the side walls, and is cut to a depth of up to 600 meters below the adjacent slope.

Outside the canyon the area can be described in terms of outer continental shelf, shelf break, upper continental slope, lower continental slope, and upper continental rise (Fig. 4). The shelf break occurs at 125 to 150 meters, and is slightly shallower near the head of Alvin Canyon. No sharp topographic boundary separates the shelf from the upper continental slope, but a transition takes place over several kilometers from a nearly horizontal surface to the gentle $\left(1.4^{\circ}\right)$ inclination of the upper continental slope. This transition zone will be referred to as the shelfbreak. Between about 750 meters and 1800 meters the continental slope steepens to an average $7.6^{\circ}$. At the base of this steep section the bottom decreases in gradient. At 
Figure 3. Bathymetry of the study area. Contours in meters below sea level, corrected for variations of the speed of sound in sea water (Matthews, 1939). 


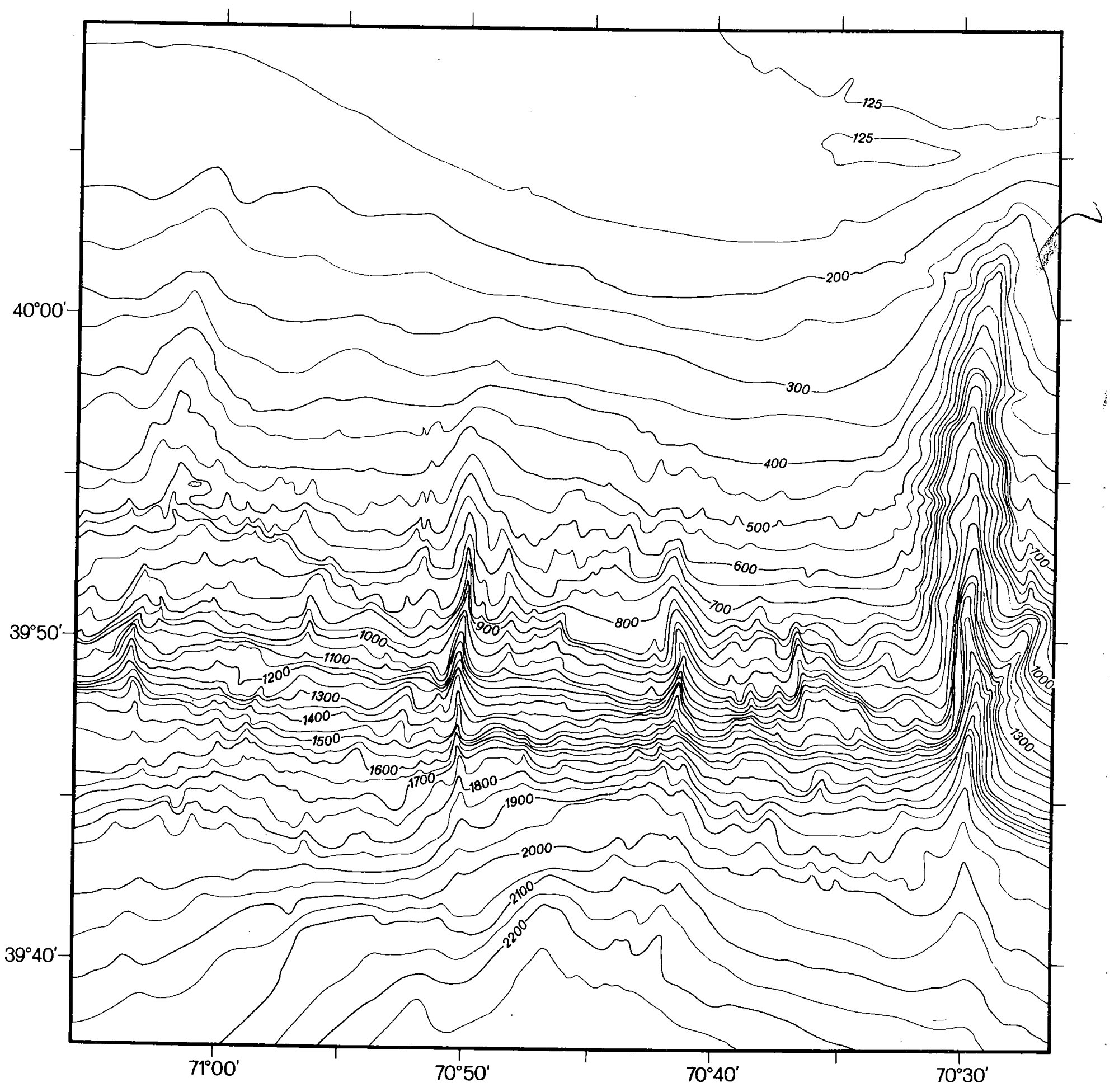

Figure 3. 
Figure 4. Bathymetric profiles of the continental slope showing shelf break area, upper continental slope, lower continental slope, and upper continental rise. Vertical exageration is about 4.2:1. Actual inclinations and corresponding gradients are given for the exaggerated slopes shown by the angles above representative portions of the profiles. 


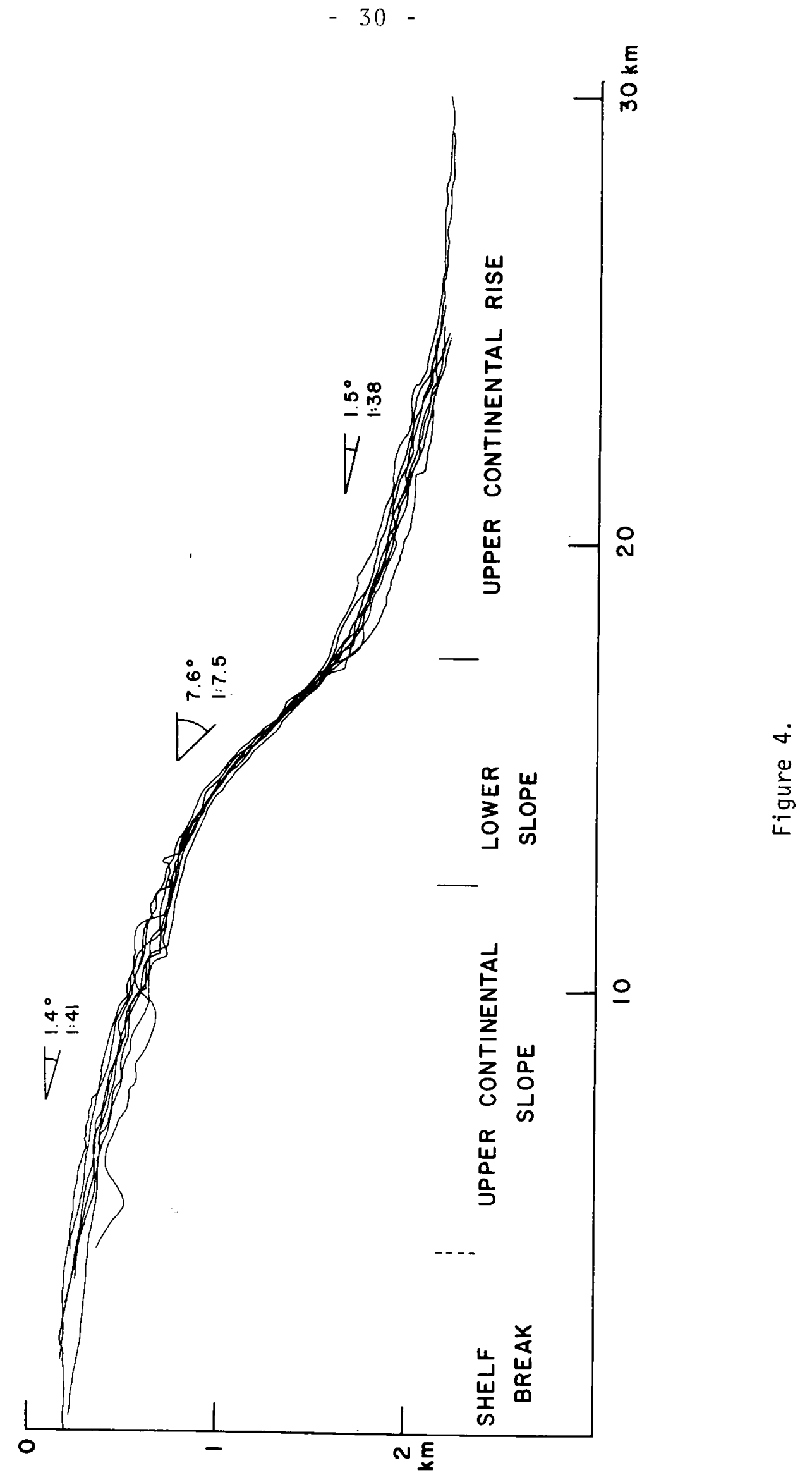


2000 meters the gradient is $1.5^{\circ}$.

Numerous gullies incise the surface of the continental slope. These range in size from large gullies approaching canyon size (as at $70^{\circ} 50^{\prime} \mathrm{W}$ in Fig. 3) to very small gullies at the limits of resolution of the echosounder. Gullies are most abundant on the steep lower continental slope, and generally trend downslope. $3.5 \mathrm{kHz}$ ECHOSOUNDING

$3.5 \mathrm{kHz}$ echosounding was performed on four cruises in the study area (Table 1); the most complete and evenly spaced lines were chosen for detailed study (Fig. 5). Bottom and sub-bottom reflections were traced directly from the records, reduced photostatically using a Xerox 1860 printer, adjusted to constant vertical exaggeration and combined into a three-dimensional drawing (Fig. 6). In addition, portions of the records were photographed directly.

The provinces defined on the basis of physiography (shelf break, upper continental slope, lower continental slope, and upper continental rise) have distinct characteristics revealed by $3.5 \mathrm{kHz}$ profiles.

The shelf break zone is smooth on a scale of several 
Figure 5. Positions of $3.5 \mathrm{kHz}$ profiles. Portions marked by wide lines and letters were photographed directly and are reproduced as figures 7 through 15 . 


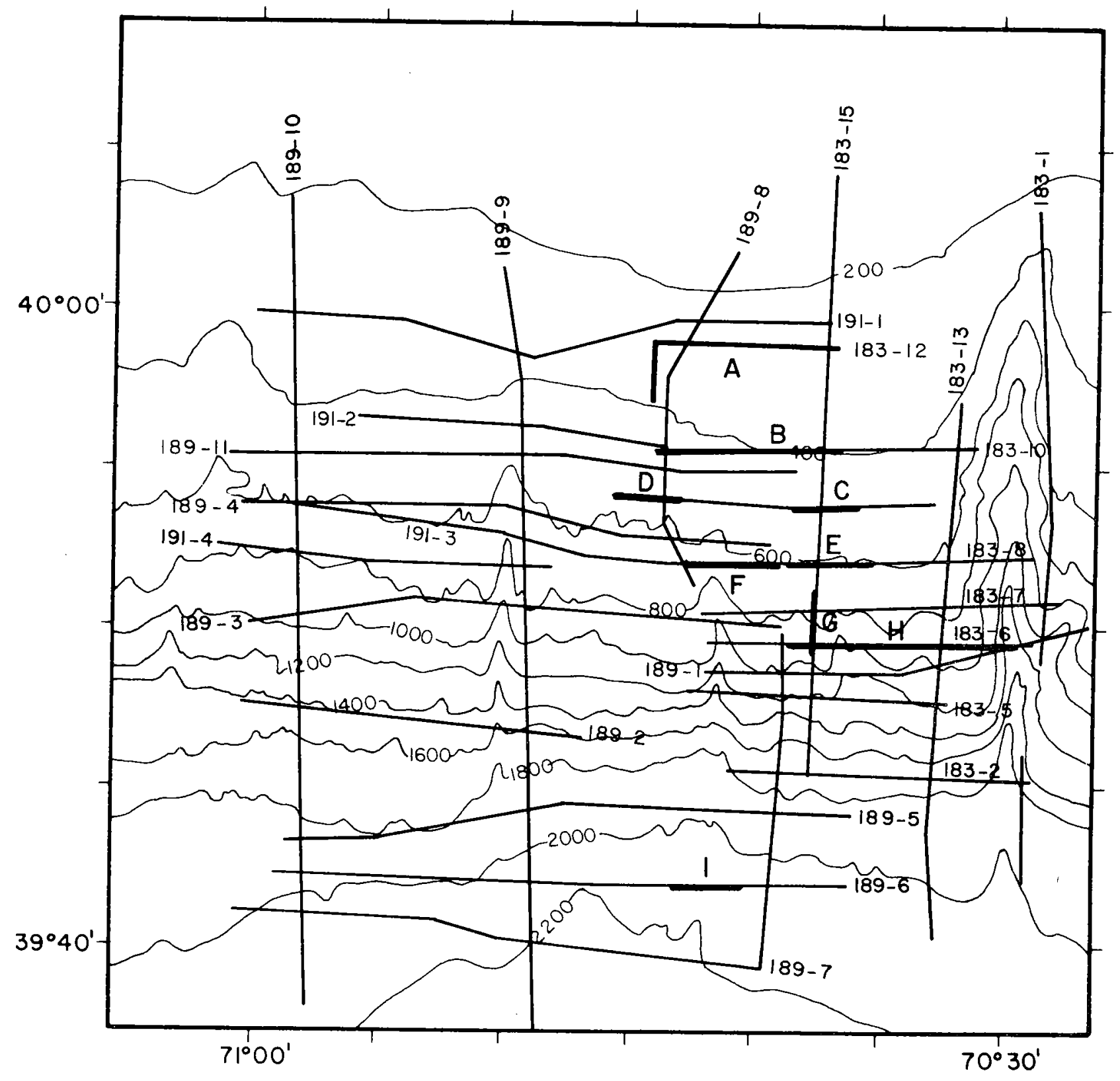

Figure 5. 
kilometers, having no large-scale relief (Fig. 6). The surface is not completely smooth, however, but has the form of rounded crests separated by V-shaped depressions with a relief of five to ten meters (Fig. 7). The track spacing was too large to detect linearity, but the features are more pronounced in east-west profiles than in north-south profiles, suggesting that they may be small gullies trending predominantly downslope. The evidence for this interpretation is not decisive. It is possible that the features are not linear, but have the form of isolated highs and lows. The spacing of crests is not strikingly regular, but the surface has this rough form over a large area of the outer continental shelf and upper continental slope (Fig. 6) suggesting that the process responsible for producing the relief may be active uniformly over the entire area.

Seaward of the shelf break sub-bottom reflections gradually become apparent (Fig. 8). These reflectors are generally parallel to the sediment surface and appear to continue uninterrupted upslope into the shelf break area, where they fade out, perhaps because they are masked by a strong surface reflection. The sub-bottom reflection sur- 
Figure 6. Three-dimensional drawing of $3.5 \mathrm{kHz}$ profiles. The base of the drawing is 2500 meters below sea level. Vertical-scale lines are at 1000 and 2000 meters. Vertical exaggeration is approximately 9 to 1 . 


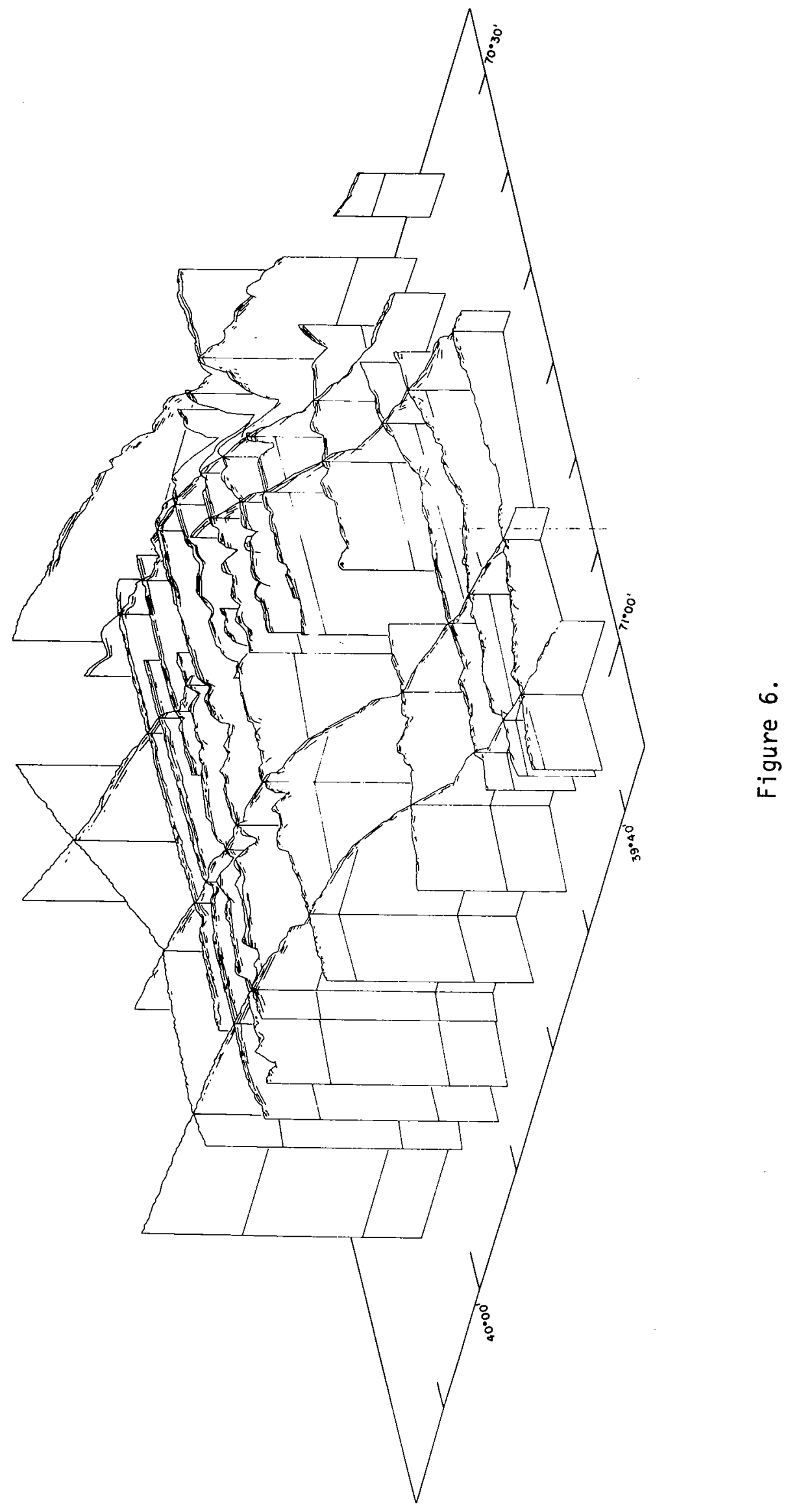


Figure 7. Portion A (Fig. 5) of $3.5 \mathrm{kHz}$ profile of the shelf break area, showing strong surface reflector, lack of sub-bottom reflections, and irregular surface. Vertical exaggeration is approximately 44 to 1 . 




范 
Figure 8. Transition from shelf break (on right) to' upper continental slope, Portion B of Figure 5. Note gradual appearance of sub-bottom reflections downslope. Vertical exaggeration of this section is approximately 22 to 1 . 


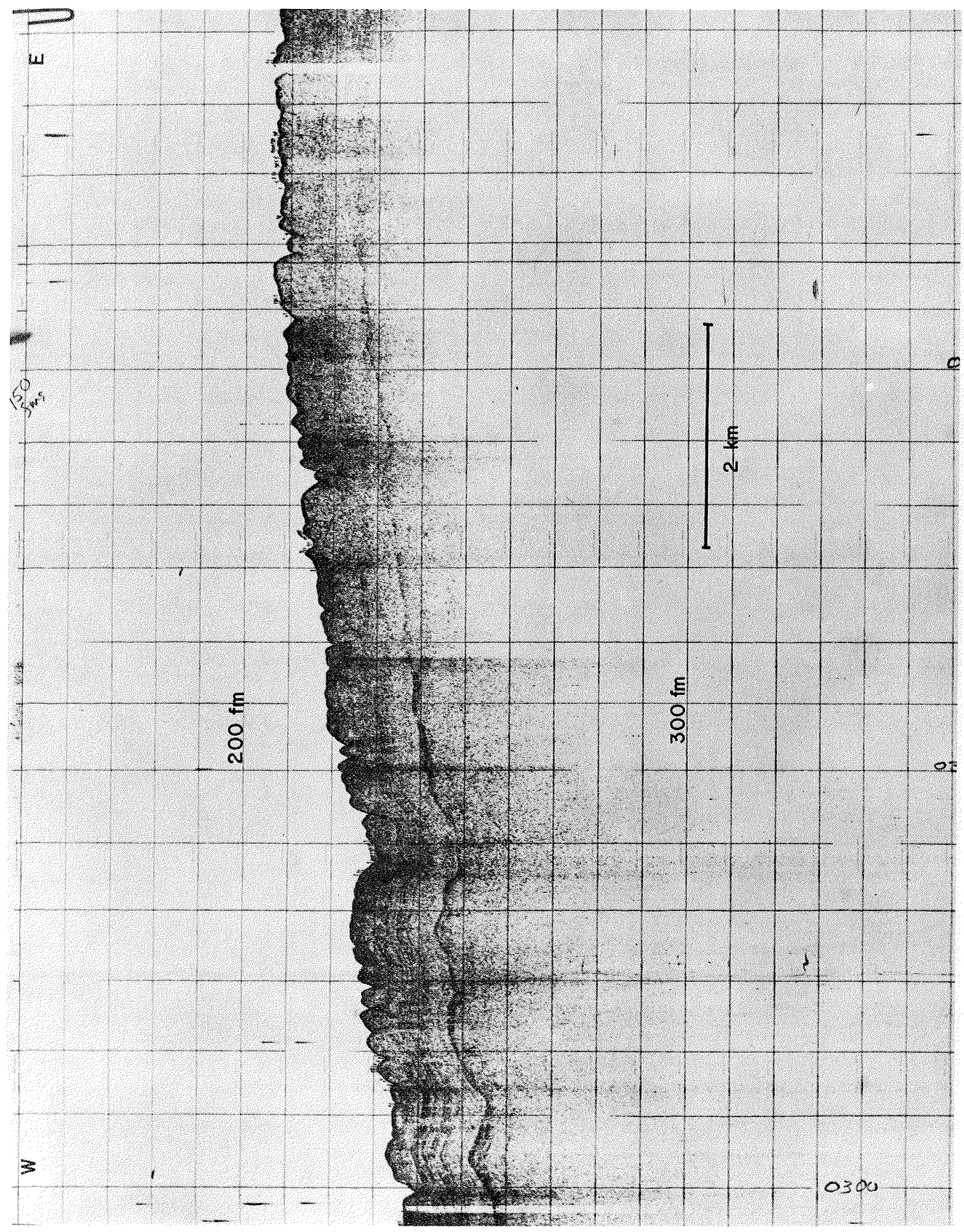

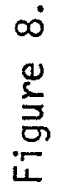


faces are strikingly concordant and continuous (Figs. 8, 9). They generally parallel the sediment surface, but they are smooth, and do not follow the sma11scale relief of the surface.

Sub-bottom reflections are clearly truncated by the numerous small gullies on the upper continental slope (Fig. 10). Most of the gullies on the upper continental slope are steep-sided, tens of meters of relief, and have hummocky floors with a layer of acoustically transparent sediment overlying one or more sub-bottom reflectors which continue under the adjacent parts of the upper continental slope (Fig. 10). The appearance of these profiles strongly suggests that the uppermost sediments have been locally removed by mass downslope movement, leaving only a disturbed residue in their former positions.

Slightly farther downslope, near the transition from the upper continental slope to the steeper lower continental slope, erosional gullies apparently coalesce to form large erosional surfaces (Figs. 11, 12) with the same hummocky-surfaced, transparent residual deposit as in the smaller gullies upslope. This lower portion of the upper continental slope is also dissected by a few large V-shaped 
Figure 9. Typical portion of $3.5 \mathrm{kHz}$ record from the upper continental slope, section C in Figure 5. Note concordant internal reflectors. Vertical exaggeration is approximately 15 to 1 . 


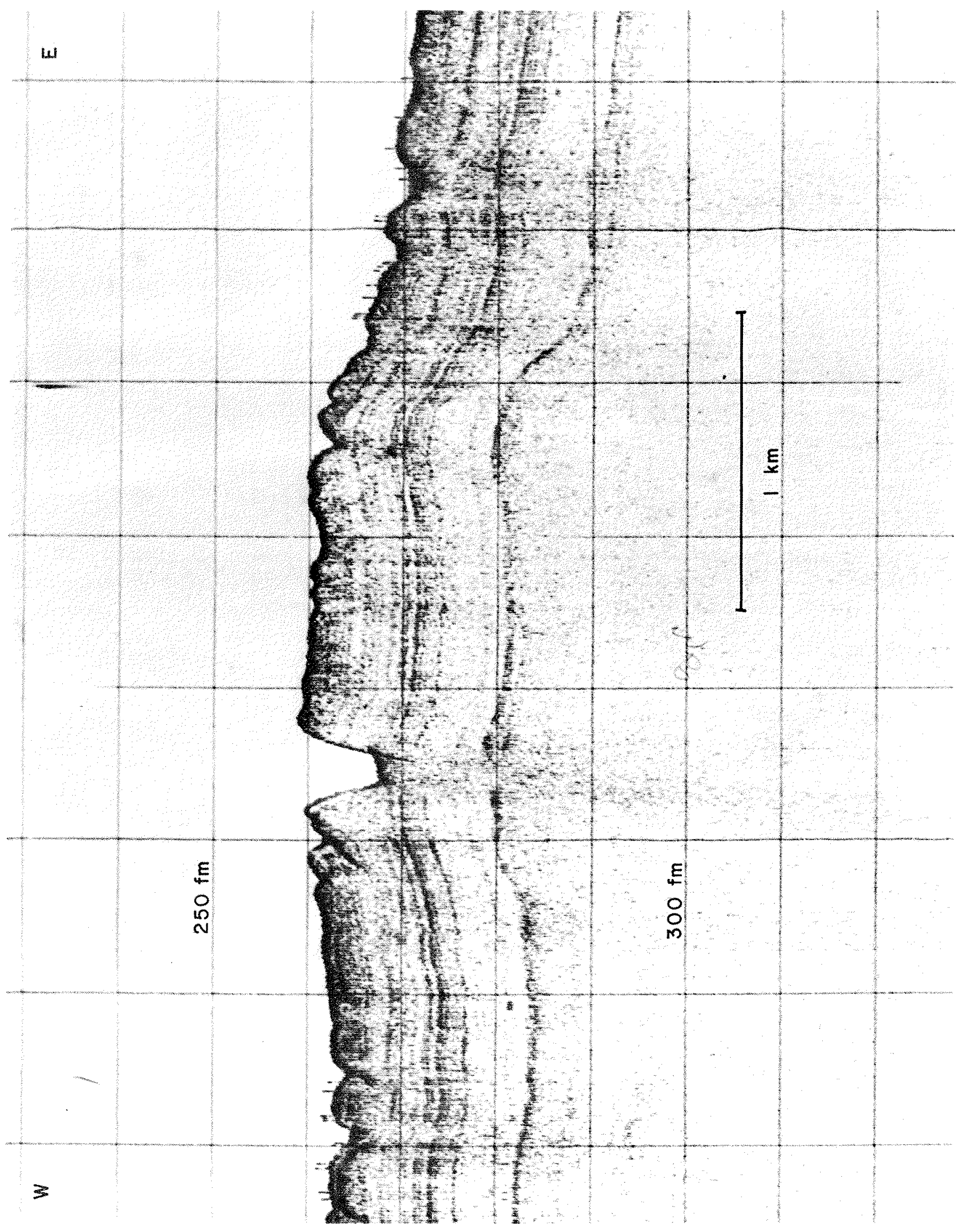

0
0
$\frac{0}{5}$
in 
Figure 10. Section D (Fig. 5) of $3.5 \mathrm{kHz}$ profiles, showing steep-sided gullies on the upper slope with a layer of apparently disturbed material in the gully bottoms. Vertical exaggeration is approximately 17 to 1 . 


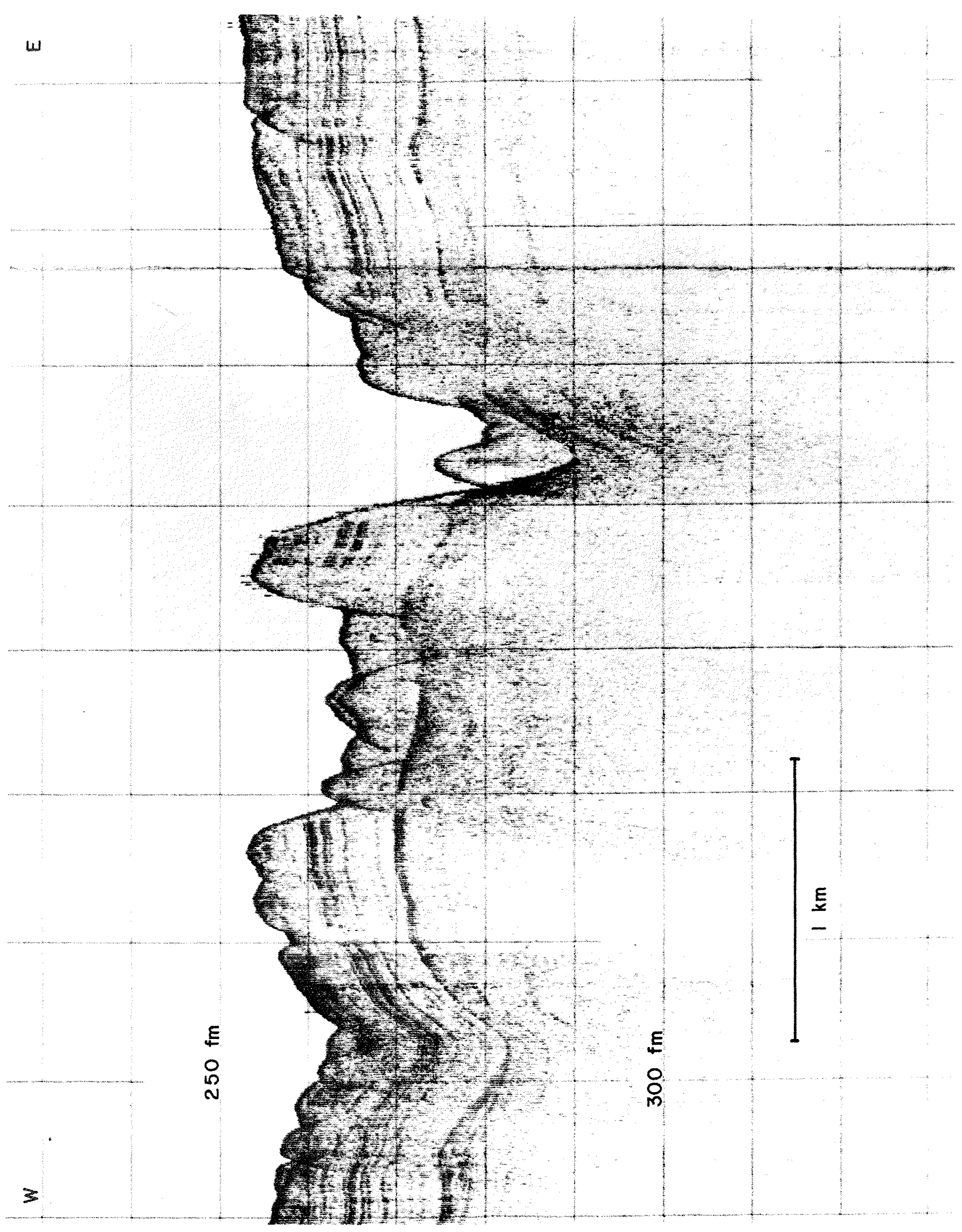

0
0
0
$\frac{0}{3}$
兵 
Figure 11. Extension of erosional feature over a large area near the transition to lower continental slope (Portion E of Fig. 5). Note steep scarp and layer of apparently disturbed material overlying undisturbed reflections. Vertical exaggeration is approximately 17 to 1. 


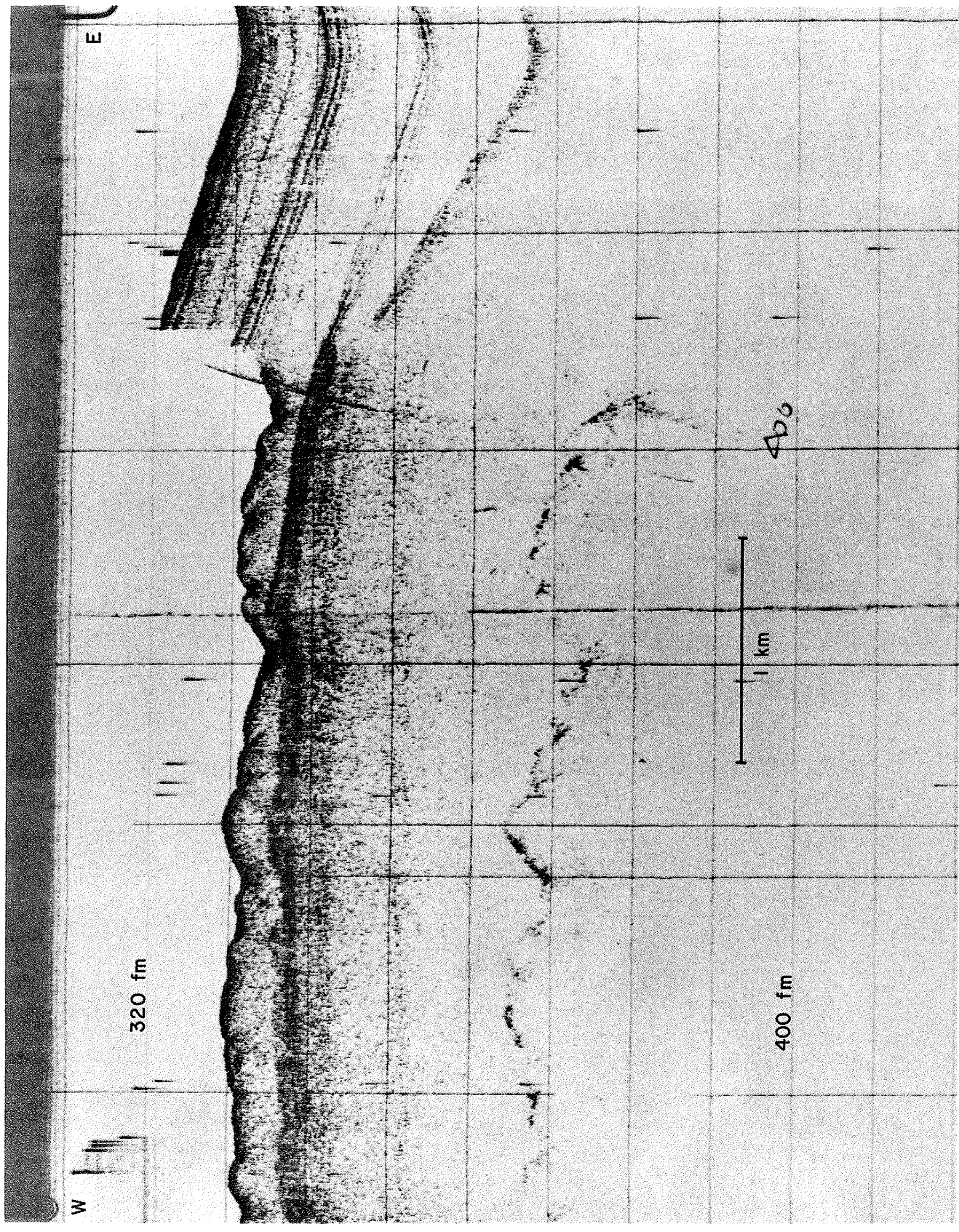

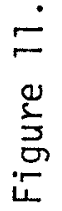


Figure 12. Section F, an extension to the west of section E of Figure 11. Note truncation of reflectors, especially on the right-hand wall of the Vshaped gully. Vertical exaggeration is approximately 17 to 1 . 


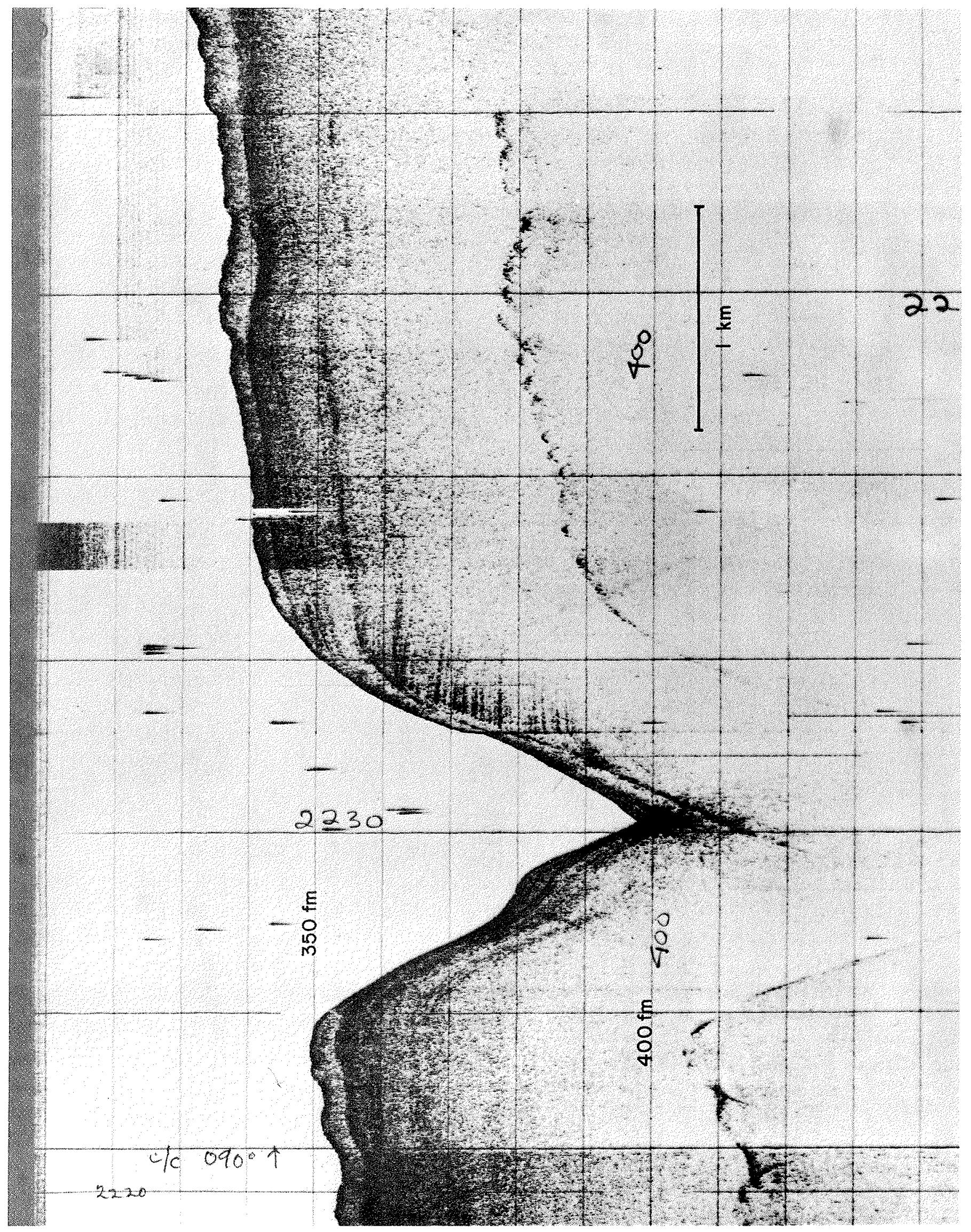

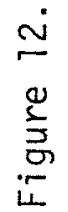


gullies which clearly truncate sub-bottom reflection sequences (Fig. 12).

North-south profiles trend approximately normal to the trend of the regional isobaths, and each shows one or more seaward facing scarps on the upper continental slope near the transition to the steeper lower continental slope (Fig. 6). These steplike features are of the order of 100 to 200 meters high, with slopes of approximately 12 degrees. The scarp surfaces apparently result from large-scale slumping, clearly truncate sub-bottom reflections in the manner of normal faulting (Fig. 13).

The lower continental slope has relatively less area of the undisturbed concordant reflection sequences compared to the upper continental slope, and relatively more area of apparently eroded bottom (Fig. 6). East-west profiles show steep-sided gullies similar to those of the upper continental slope, with both V-shaped and flat floors (Fig. 14). Little if any of the hummocky, residual material common on the upper continental slope is observed in gullies on the lower continental slope.

North-south profiles on the lower continental slope show reflection sequences to be subparallel to the sedi- 
Figure 13. Seaward-facing scarp on the upper continental slope, Portion $G$ on Figure 5. Note offset of near surface reflectors. Vertical exaggeration is approximately 16 to 1 . 


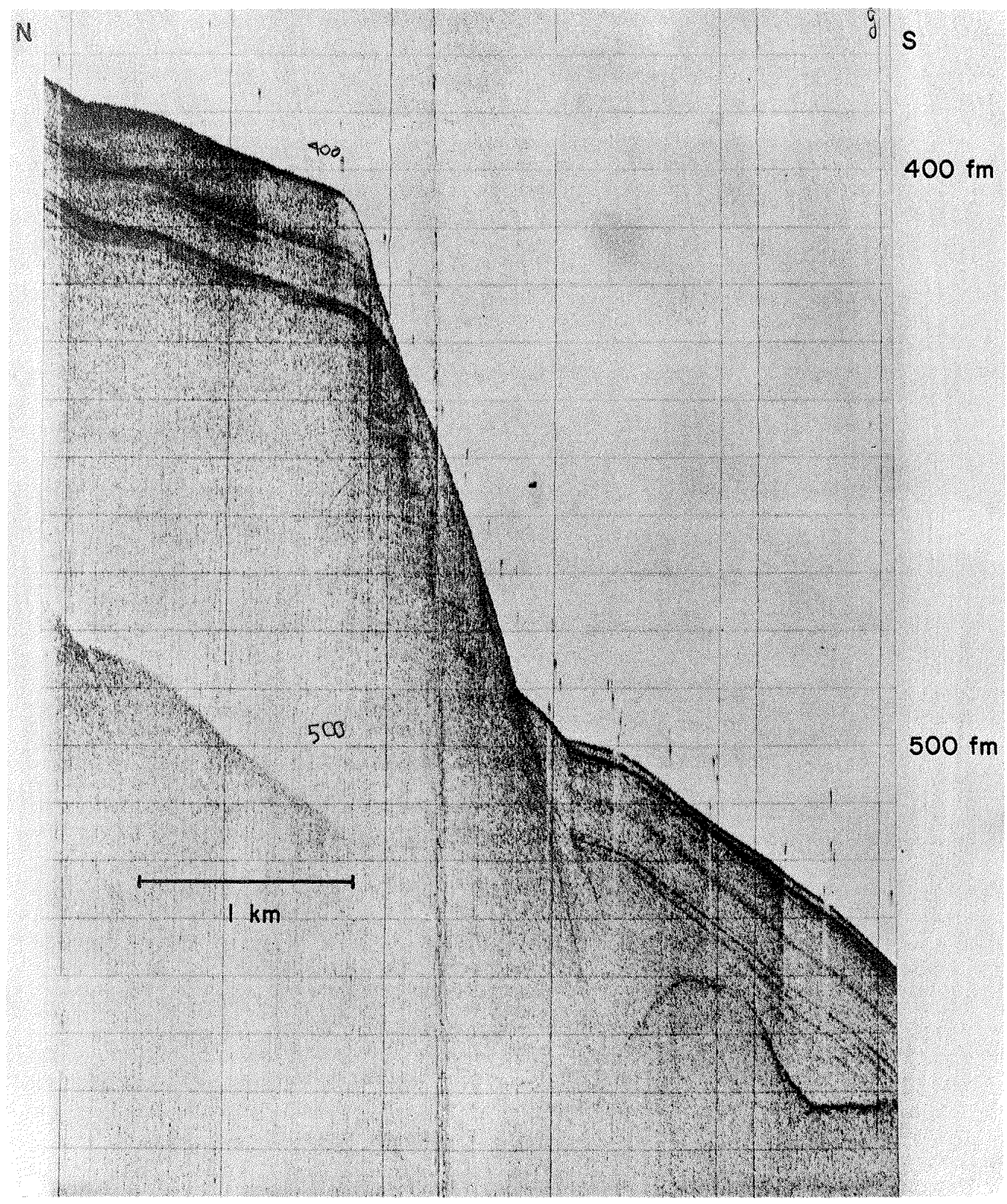

Figure 13. 
Figure 14. Gullies on the steep lower continental slope, Portion $\mathrm{H}$ of Figure 5 . Note absence of disturbed material in gullies. Vertical exaggeration is approximately 32 to 1 . 


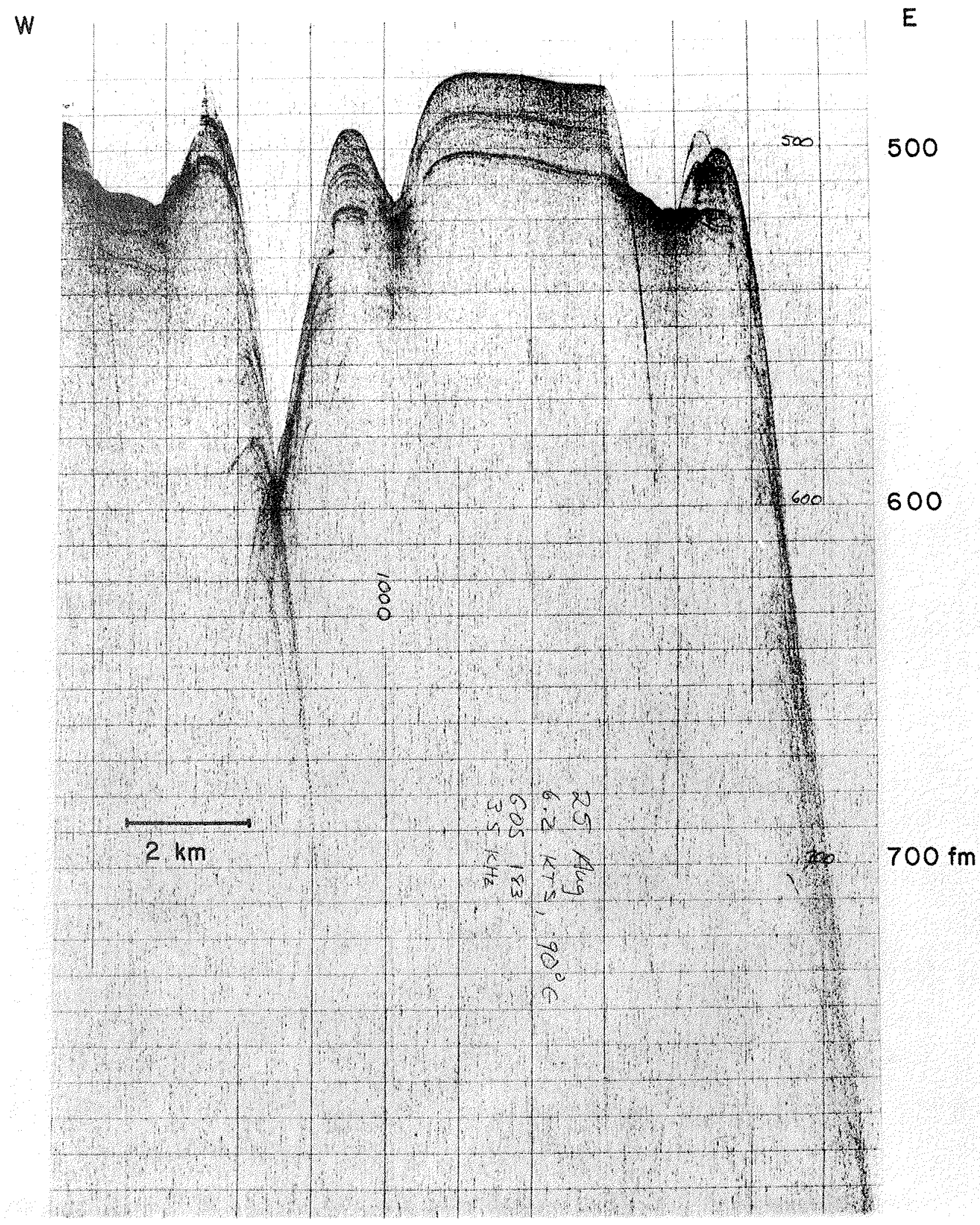

Figure 14. 
ment surface, cropping out in steep portions of the profiles (Fig. 6). Steep scarps similar to those of the upper continental slope are present on the lower continental slope as well, but they are less sharply defined on the lower continental slope because of the steeper regional gradient.

The upper continental rise is characterized. by hummocky, irregular topography with many hyperbolic reflections and generally discordant, discontinuous internal reflections (Fig. 15). A large portion of the bottom is composed of transparent material, and where coherent sequences of reflections appear they are often tilted with respect to the surface.

The transition from steep lower continental slope to upper continental rise takes several different forms in various north-south profiles. In some profiles the rise material appears to be deposited at the foot of the continental slope as a highly disturbed transparent layer, while in other profiles the reflection sequence continues undisturbed from continental slope to upper continental rise. SEISMIC REFLECTION PROFILES 
Figure 15. Typical portion of $3.5 \mathrm{kHz}$ profile of the upper continental rise just below the foot of the continental slope. Vertical exaggeration is approximately 13 to 1 . 


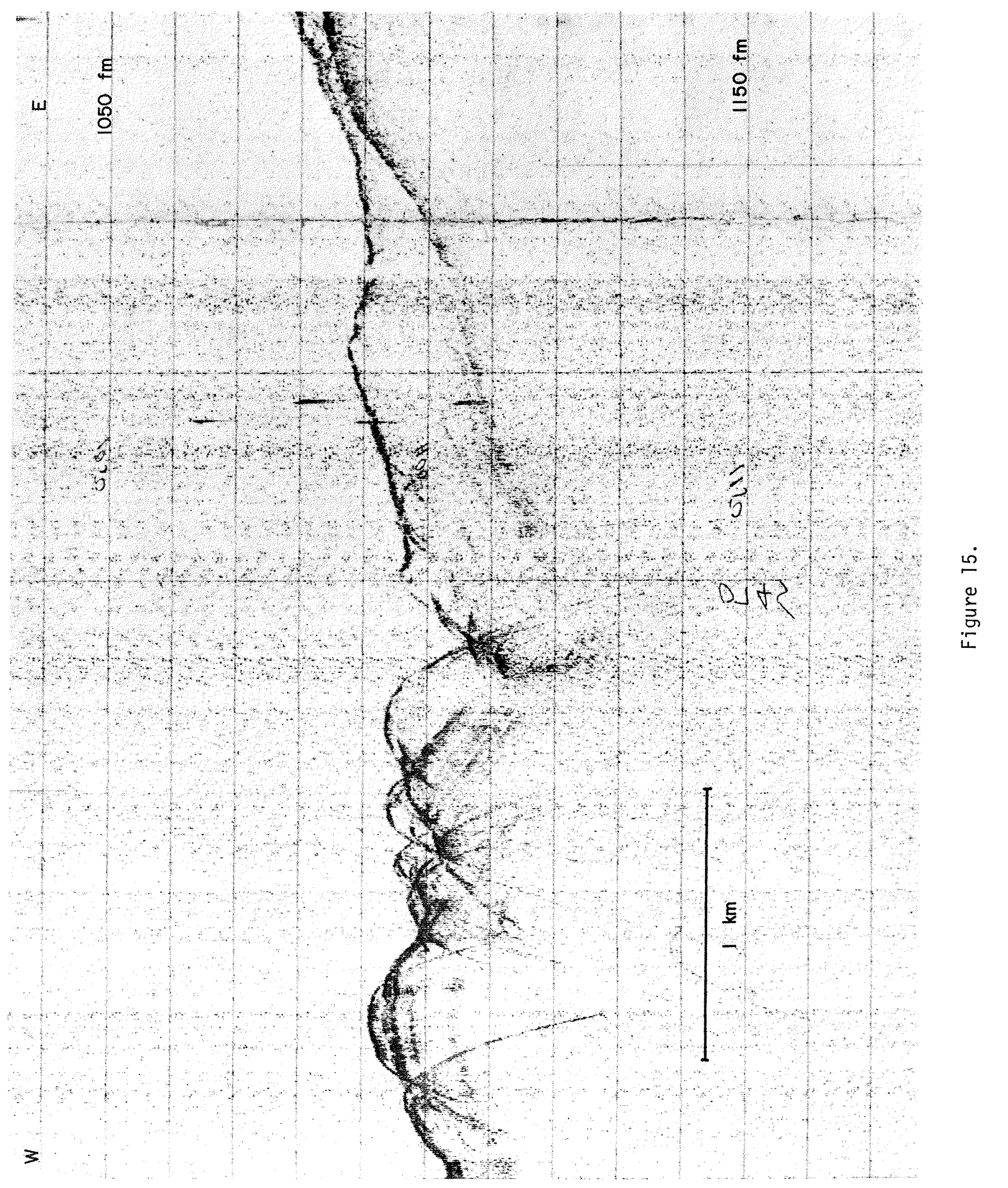


Seismic reflection profiling was performed during ATLANTIS II Cruise 72 (Table 1, Fig. 16) using a ten cubic inch air gun fired at five-second intervals. Bottom and sub-bottom echoes were received by two linear hydrophone arrays. The signals were summed, filtered from $18 \mathrm{~Hz}$ to $300 \mathrm{~Hz}$, and recorded on treated paper with a Precision Graphic Recorder (Knott, 1970). Surface and sub-bottom reflections were traced directly from the records and adjusted for variations in vertical exaggeration caused by changes in ship speed.

As in the case of $3.5 \mathrm{kHz}$ profiles, the seismic reflection data reveal differences between the provinces present in the study area. In general, the seismic reflection data support the $3.5 \mathrm{kHz}$ interpretations, but yield more information on deeper underlying structure and less information on detailed structure near the surface. The outer continental shelf and upper continental slope are characterized by gently dipping internal reflections, generally parallel to the sediment surface (Fig. 17). Profiles 3 and 24 show extensive zones of disturbed internal reflectors, expressed at the surface as hummocky, irregular topography, especially in Profile 3. Steep seaward 
Figure 16. Positions of seismic profiles taken on cruise AII-72 within the study area. Numbered profiles were used to construct figures 17 and 18 . 


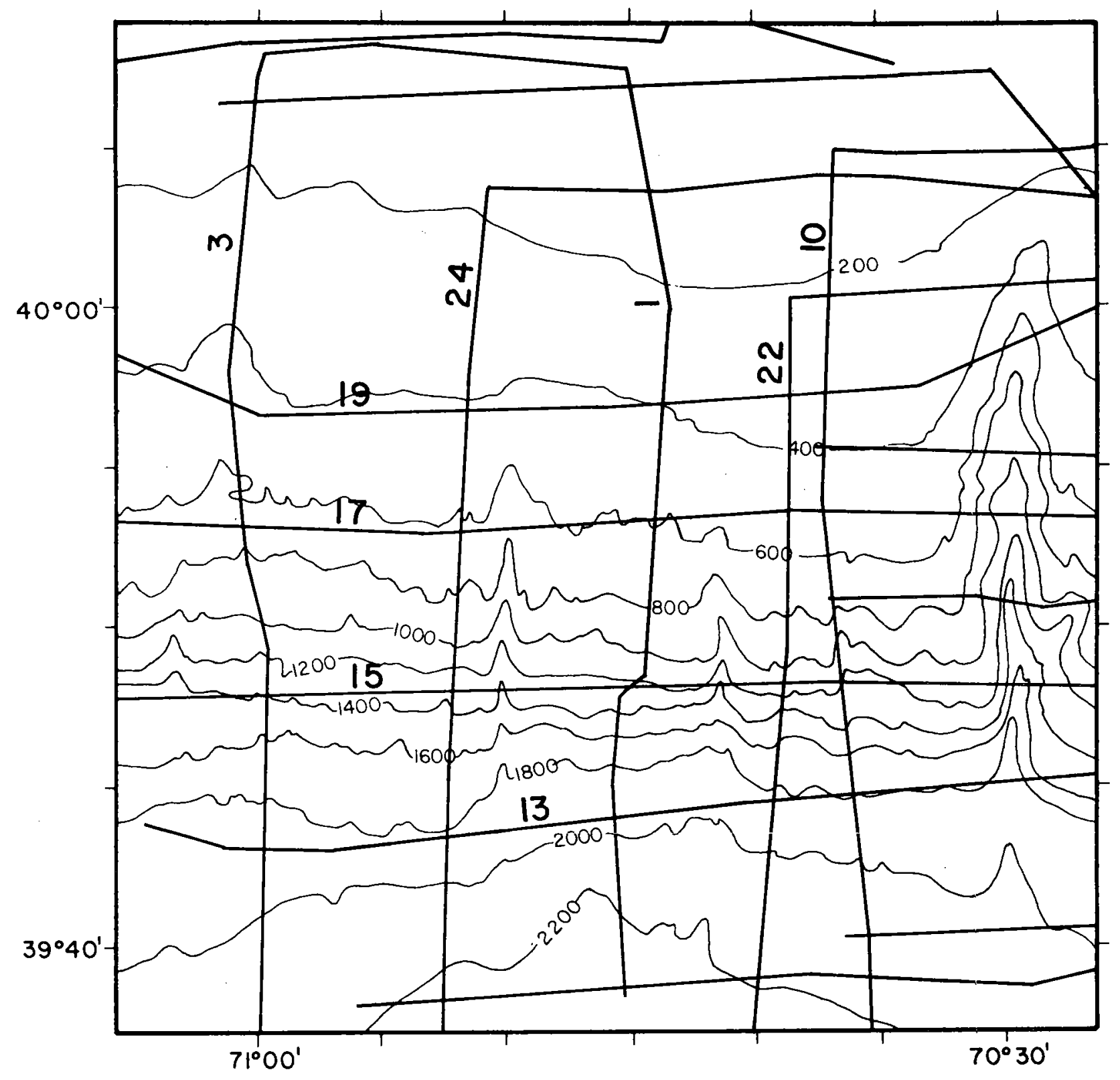

Figure 16. 
$-61-$

Figure 17. North-south seismic reflection profiles in the study area. Profile locations are shown in Figure 16. 


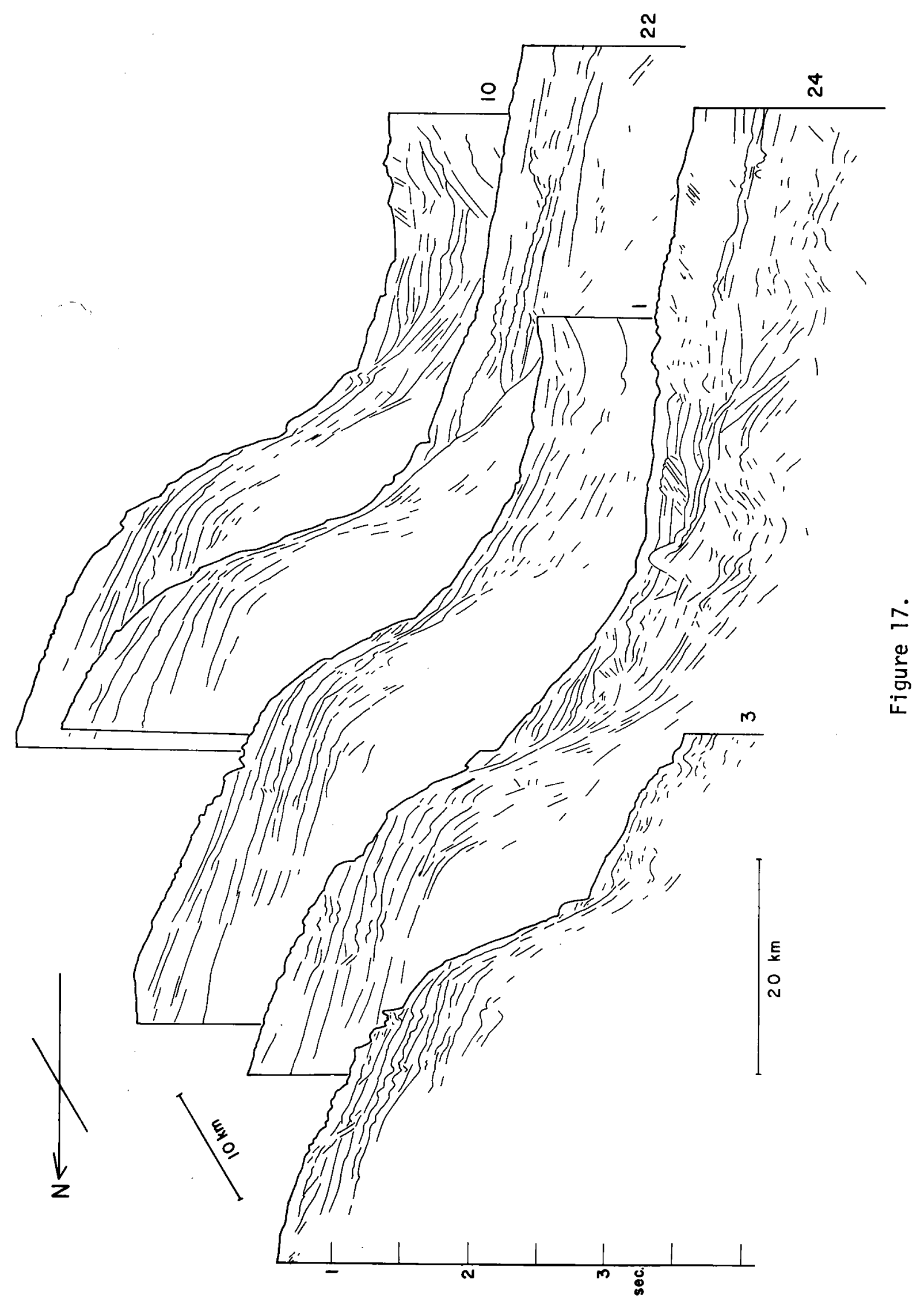


facing scarps suggest large-scale slumping near the transition between upper continental slope and lower continental slope. Internal reflection surfaces approach the surface on the lower portions of the upper continental slope. especially on the steep seaward-facing scarps, and near the transition from upper continental slope to lower continental slope.

Reflection surfaces deeper in the sediment are more nearly parallel to the present surface, displaying a change in slope and marking the position of a former transition between upper and lower continental slope or perhaps a former shelf break. Profile 19 (Fig. 18) demonstrates the generally continuous and concordant nature of the internal reflectors of the upper continental slope. Irregular surfaces are present locally within the sequence. As with the $3.5 \mathrm{kHz}$ reflectors, the near-surface reflection surfaces are clearly incised by Alvin Canyon and the numerous large gullies.

Profiles from the lower continental slope are characterized by short segments of reflections which are generally parallel to the surface in north-south profiles, but have some relief in east-west Profile 17(Fig. 18). This 
Figure 18. Line drawing made from a photograph of a three-dimensional model constructed from selected seismic reflection profiles. Profile locations are shown in Figure 16. 


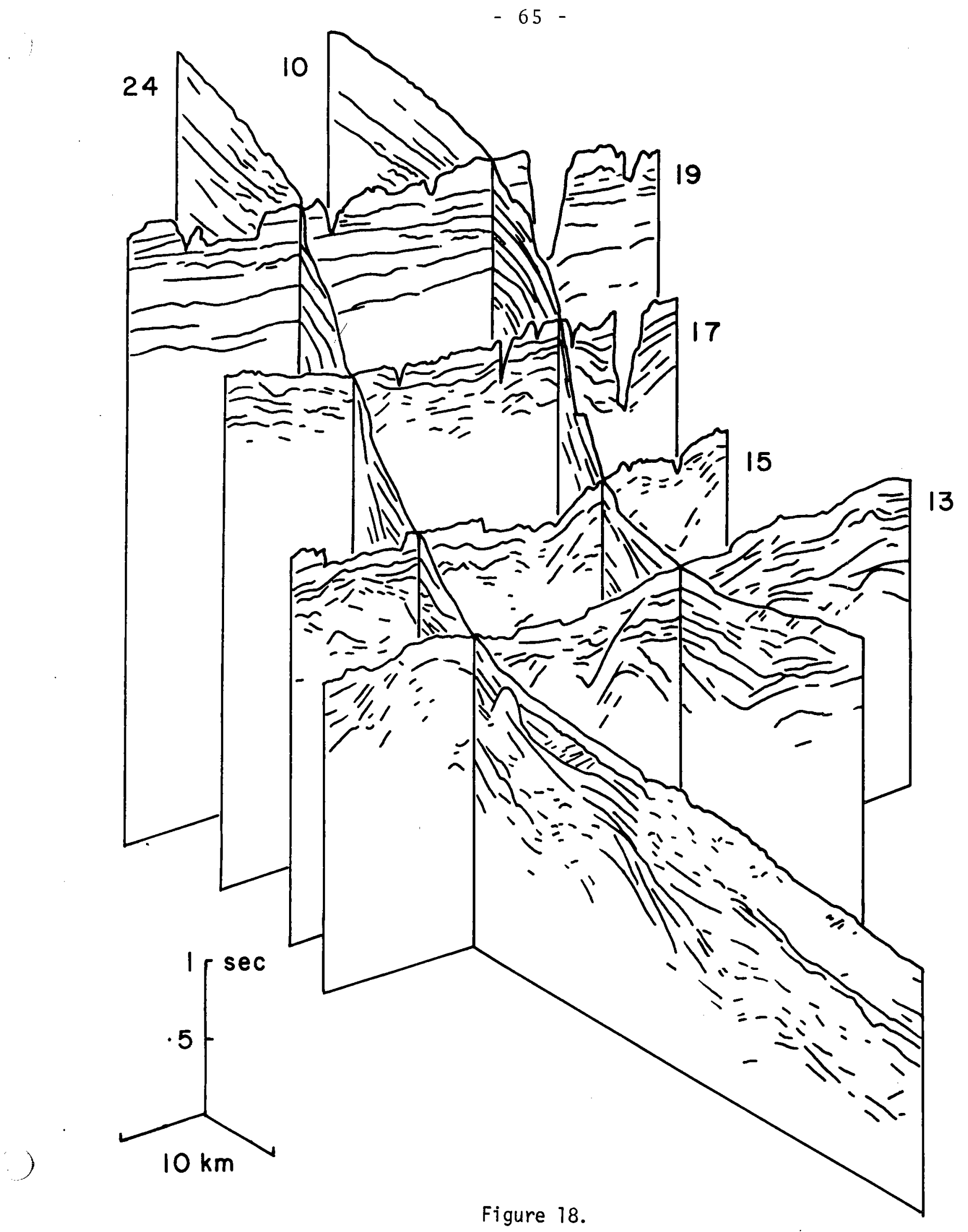


relief in the deep reflectors becomes much more marked on the upper continental rise, where basins and ridges with relief on the order of half a second two-way travel time (about 500 meters) underlie the relatively smooth surface. The north-south profiles vary markedly in structure between adjacent profiles (Fig. 17). Profile 24 displays the most complex deep structure, containing basins and highs, a large block of nearly transparent sediment, an apparently displaced mass of sediment which buries the foot of the lower continental slope, and small discrete blocks of sediment with concordant landward-dipping reflections. In contrast, the adjacent profile 1 seems to cross a relatively simple single basin structure. This variation in structure over distances of a few $\mathrm{km}$ suggests that the bulk of the material in this part of the upper continental rise is derived from directly upslope.

All north-south profiles show the deeper lower continental slope reflectors continuing seaward under the upper continental rise, forming one or more angular unconformities overlain by blocks of sediment with generally concordant internal reflections, suggesting that large blocks of sediment have been emplaced at the foot of the 
continental slope by slumping. SUSPENDED SEDIMENTS

Suspended-sediment samples were taken during a fiveday period in late October, 1972, at the positions shown in figure 19. All deep-water samples were taken in clean 30-liter Niskin bottles positioned with respect to the bottom by a pinger suspended 5 meters below the lowest bottle. Surface water samples were taken either with a 30-1iter Niskin bottle or with a clean plastic bucket lowered over the side of the ship. Three samples were taken at each of 6 stations: one 15 meters from the bottom, one at middepth, and one at the surface. Samples were immediately filtered through two preweighed Nuclepore filters with nominal pore diameters of $.37 \mathrm{\mu m}$, the bottom filter for each sample serving as a blank. The filters were washed with filtered distilled water, once on the ship and again in the laboratory to remove salt. The dried filters were then reweighed and the concentrations calculated assuming that any gain or loss in the blank filters was shared by the paired sample filters (Manheim and others, 1970). Values of total suspended sediment (Fig. 20a) ranged from $287 \mu \mathrm{gm} / 1$ at the shelf break to less than $20 \mu \mathrm{gm} / \mathrm{l}$ at 
Figure 19. Positions of suspended-sediment stations within the study area. Depths of samples are indicated, with s signifying surface samples. Station AS-I marks the location of turbid bottom waters observed by television and photography in July, 1972 . 


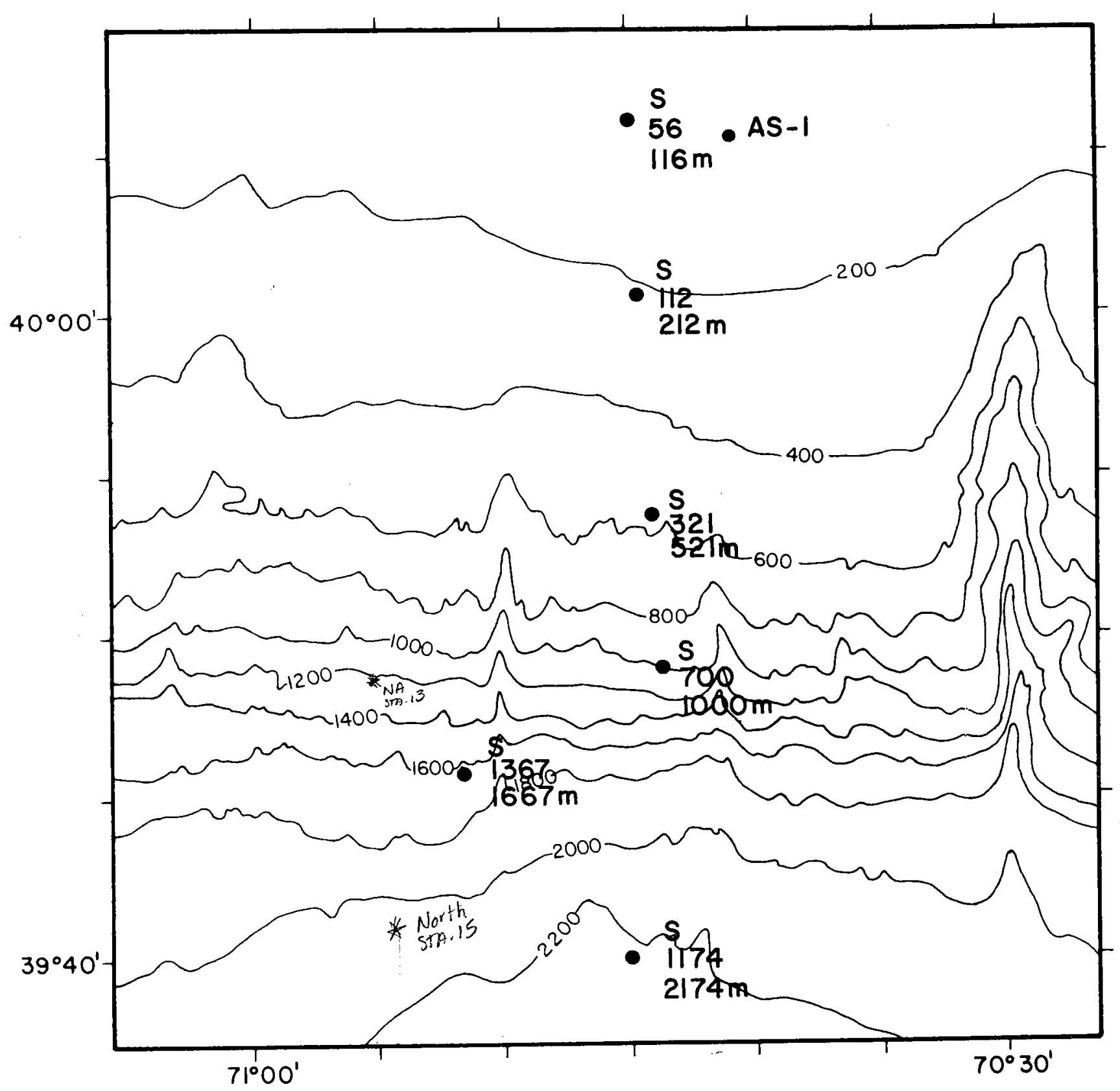

Figure 19. 
Figure 20. a) concentration of total suspended sediment at ATLANTIS II-72 stations, in units of micrograms per liter of sea water. Bathymetric profile constructed from Fig. 3 along the northsouth line passing through most of the water stations. The values of the station at 1680 meters were projected onto the profile at comparable depth.

b) concentration of inorganic residue after treatment with hydrogen peroxide, in micrograms per liter of sea water. c) concentration of organic fraction of suspended material, in micrograms per liter of sea water. 
- $71-$
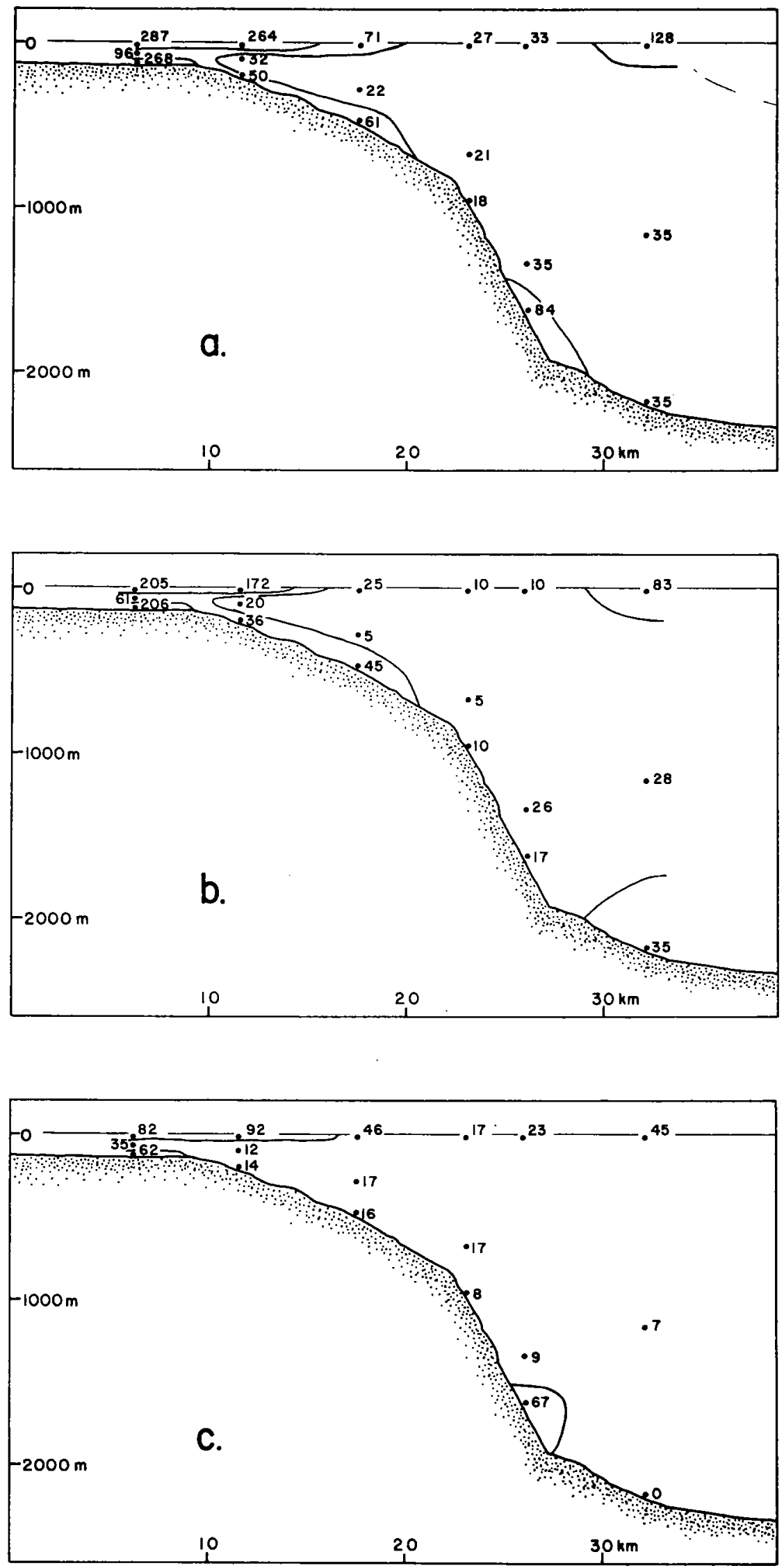

Figure 20. 
1000 meters depth. The general pattern is one of highest values at the shelf break, lower values at the surface and near the bottom on the upper continental slope, and with lowest concentrations at mid-depths near the base of the lower continental slope.

Organic matter on the filters was oxidized using a $30 \% \mathrm{H}_{2} \mathrm{O}_{2}$ solution, giving the distribution of inorganic residue shown in figure $20 \mathrm{~b}$. Both blank and sample filters were treated as a check against contamination or loss of filter weight. The pattern of inorganic suspended material is nearly identical to that of figure 20a. The organic component, however, is restricted to surface waters (Fig. 20c), except for the bottom samples at the shelf break and on the steep lower slope, both of which show values comparable to surface concentrations.

The high concentrations of inorganic suspended material at the shelf break seems to be a persistent phenomenon. During ALCOA SEAPROBE operations the previous summer (July, 1972), turbid bottom waters were observed nearby (Fig. 19) which limited bottom visibility (Fig. 21). Similar high concentrations have been observed at the shelf break farther west near the head of Wilmington Canyon 
Figure 21. Bottom photograph at station AS-1, $120 \mathrm{~m}$ water depth. See Figure 19 for location. Note poor visibility of the bottom. Pipe is marked, in $15 \mathrm{~cm}$ segments, one of which is buried in the sediment. 


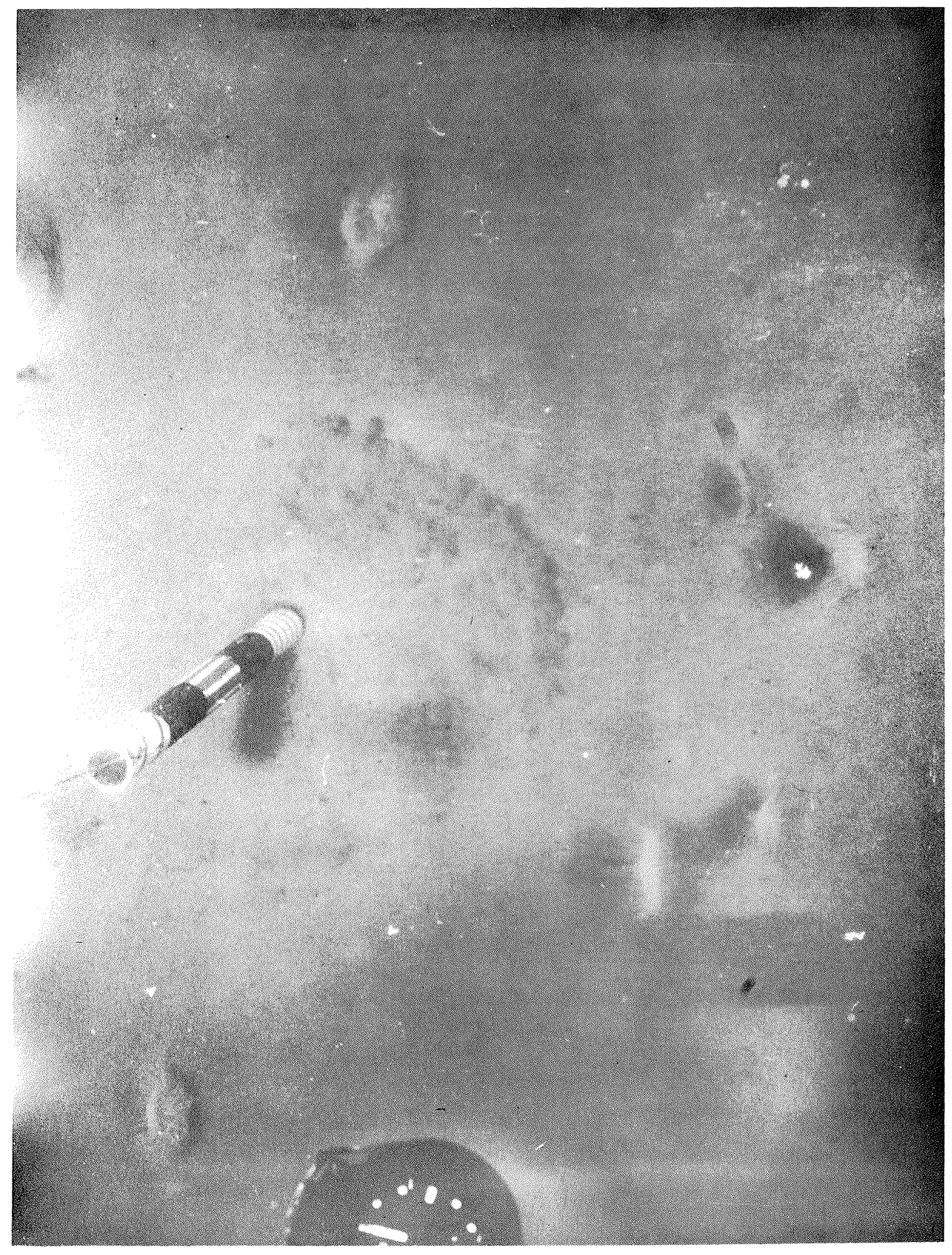

Figure 21. 
(Lyall and others, 1971), suggesting that turbid bottom water may be a widespread feature of the outermost shelf. $\mathrm{X}$-ray diffraction of the near-bottom sample from the shelf break showed a close similarity to nearby surface samples, having high proportions of illite and quartz. THE SEDIMENT-WA TER INTERFACE

Bottom photographs, television, and direct observation

More than 1000 bottom photographs were taken at 30 stations within the study area (Fig. 22, Table 1). Most of the stations were made using an EG\&G model 205 bottom contact camera. Others were made using an EG\&G camera mounted on the ALCOA SEAPROBE instrument package, so that continuous television complemented the camera system. In addition, photographs and observations from several DSRV ALVIN dives on the permanent deep bottom station were included.

The nature of the sediment surface changes dramatically over short distances near the shelf break. At station AS-1, just shoreward of the shelf break, the bottom is smooth, soft, apparently fine grained, and featureless (Fig. 21). One section of pipe, dropped to the bottom through the drill pipe suspending the instrument pod, 
Figure 22. Positions of bottom photographic stations. Stations labelled AS were taken with the ALCOA SEAPROBE instrument package. Stations marked 72 were taken on R/V ATLANTIS II cruise 72. Bottom station photographs were from DSRV ALVIN. Unpublished photographs from three dives made by Emery and Ross (1968) were taken at the location marked E/R. All other photographs are from $\mathrm{R} / \mathrm{V}$ GOSNOLD cruises 177, 183, and 191 . 


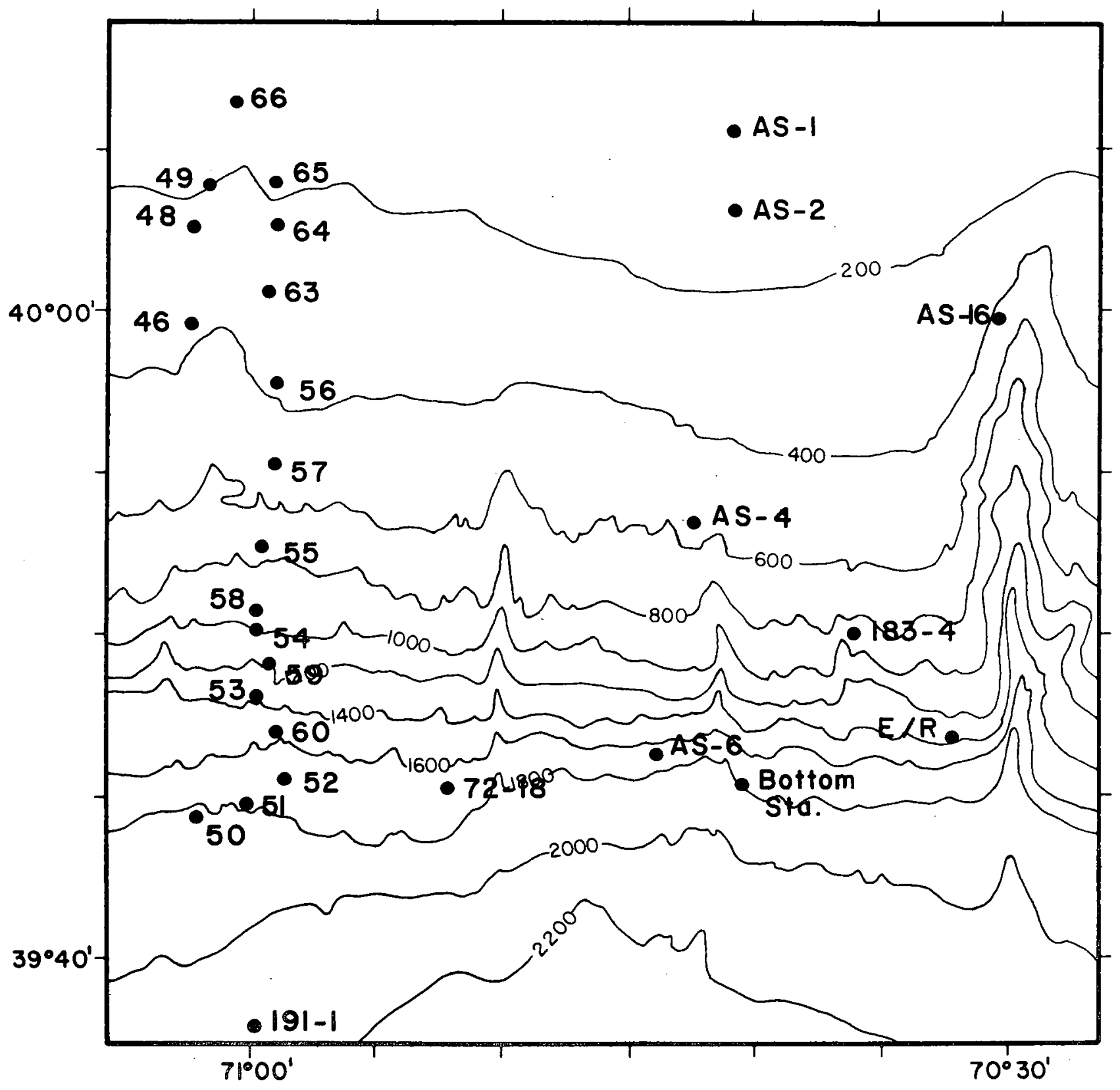

Figure 22. 
penetrated $15 \mathrm{~cm}$ into the bottom and remained upright. Another penetrated the same distance and then fell over. The epifauna at this station was dominated by the burrowing anemone Cereantheomorphe.

Just $3 \mathrm{~km}$ south of station $\mathrm{AS}-1$, at station $\mathrm{AS}-2$, the nature of the sediment surface was completely different. At station AS-2 (Fig. 23), the sediment is coarse grained. Television monitoring revealed that mechanical disturbance of the sediment produced only a small cloud of sandy suspension which settled immediately. A pipe section dropped onto this surface did not penetrate. Light-colored biogenic fragments litter the surface, and mobile species such as hake and the crab Cancer dominate the epifauna. Photographs from stations at 190 and 200 meters (stations 45 and 65, Fig. 22) recorded a thin zone of transitional nature between the shelf break and the upper continental slope, with occasional burrows and scarce tracking of the bottom (Fig. 24). The epifauna is dominated by the crab Cancer borealis, the crustacean Munida iris, and the flexible armed brittle star Ophiacantha.

At station 63 at 290 meters depth, striking lineations were photographed (Fig. 25), which appear to be due to 
Figure 23. Photograph from station AS-2, at the shelf break, at approximately 140 meters water depth. Location is shown in Figure 22. Pipe is approximately $1 \mathrm{~m}$ long, divided in $15 \mathrm{~cm}$ sections. 




Figure 23. 
Figure 24. Photograph from station 65, 190 meters water depth. Location is shown in Figure 22. Photographs in Figures 24-29, 33, and 34 were taken with a bottom contact camera. The field of view is approximately $1.3 \times 2$ meters. The arm in the field of view holds a compass. Note burrows and arms of the abundant brittle stars. 


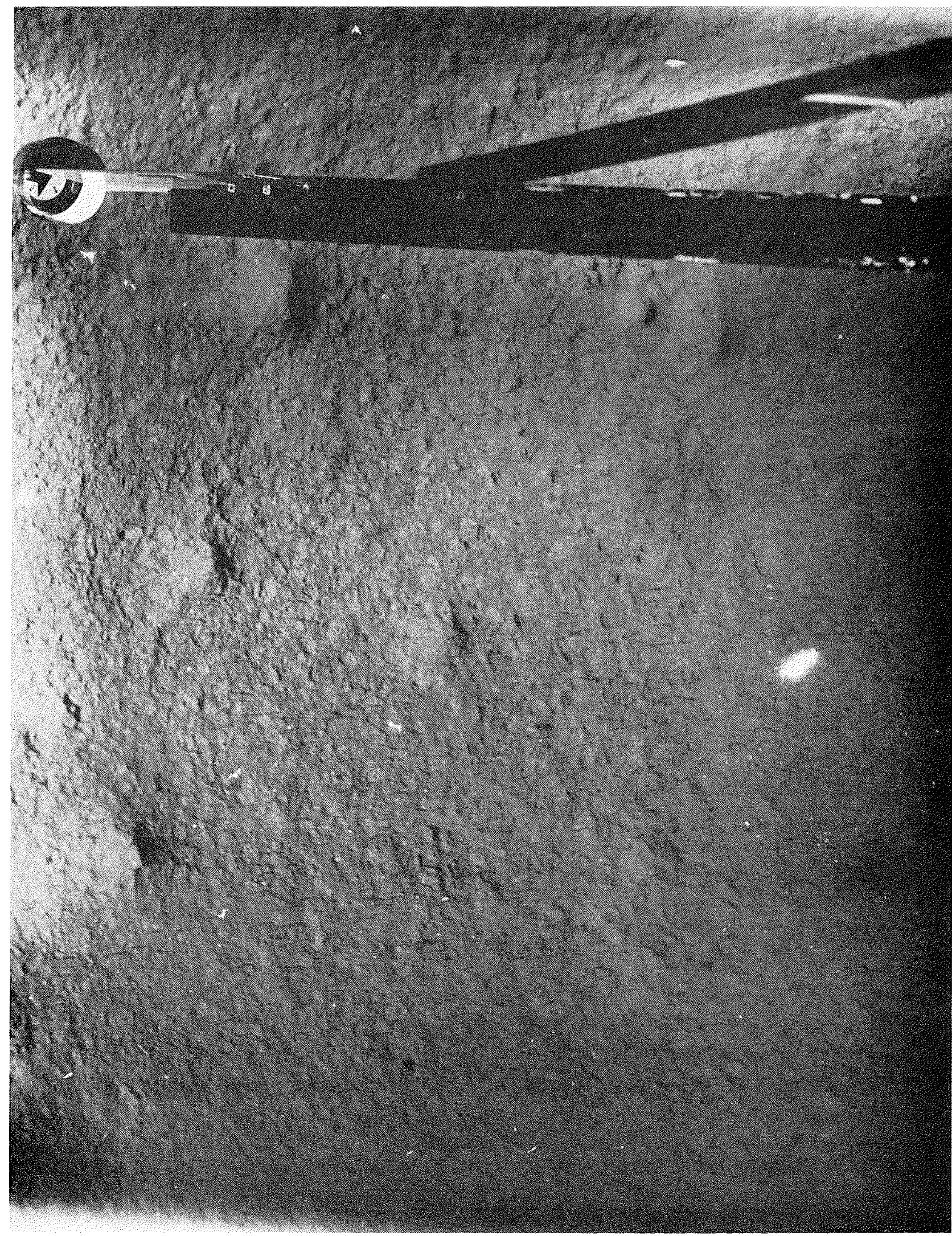

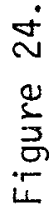


Figure 25. Photograph from station 63, at 290 meters on the upper continental slope. Note lineations trending southeast-northwest. Field of view is $1.3 \times 2.0$ meters. 


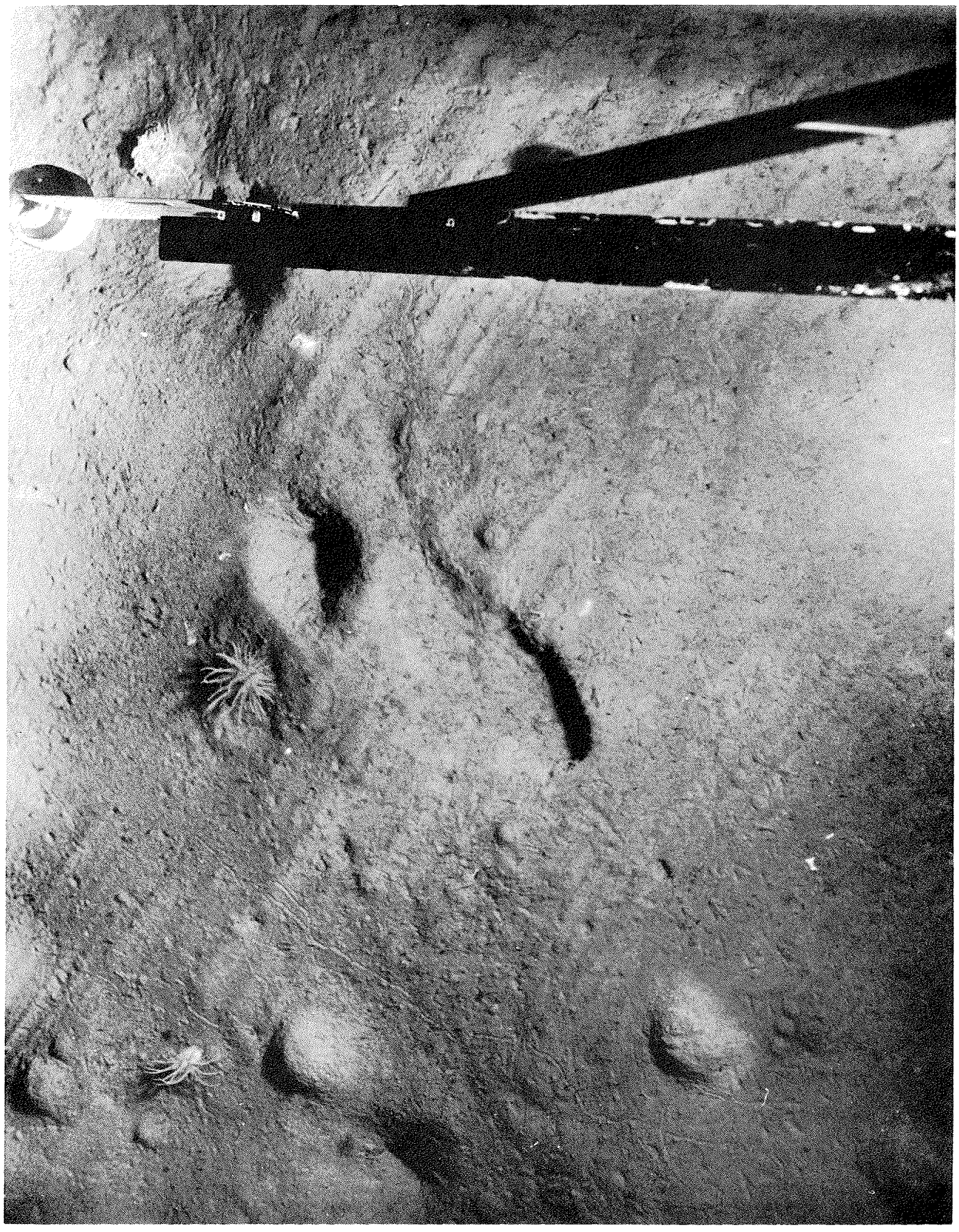

ำ
0
$\frac{1}{3}$
$\frac{1}{4}$ 
current scour. The distribution of these marks on the bottom is patchy, and the marks are clearly present in only about half the photographs from this station, but they occur in photographs along the entire length of the kilometer that the ship drifted during photography, and have the same southeast-northwest trend in all photographs in which they appear.

Photographs from the upper continental slope are characterized by abundant burrows, mounds, animal tracks, and shallow excavations (Fig. 26). The epifauna is diverse but is dominated by the crab Cancer borealis, flounder and hake, several species of anemones, sea pens, and the quill worm Hyalinoecea artifex. The markings of these animals cover the bottom completely. The bottom on the upper continental slope is firm, holding the shape of burrows and tracks, but a section of pipe dropped to the bottom from the instrument package on ALCOA SEAPROBE at station AS-4 penetrated over $30 \mathrm{~cm}$ into the sediment, indicating a much softer surface than at the shelf break.

The surface of the lower continental slope is much more variable than that of the upper continental slope. Four distinct types of bottom are observed on the lower 
Figure 26. Photograph from station 56 at 400 meters water depth. Location is shown in Figure 22 . Field of view is $1.3 \times 2.0$ meters. Note the relatively smooth texture of the bottom (compare to Fig. 27), and abundant animal markings. 


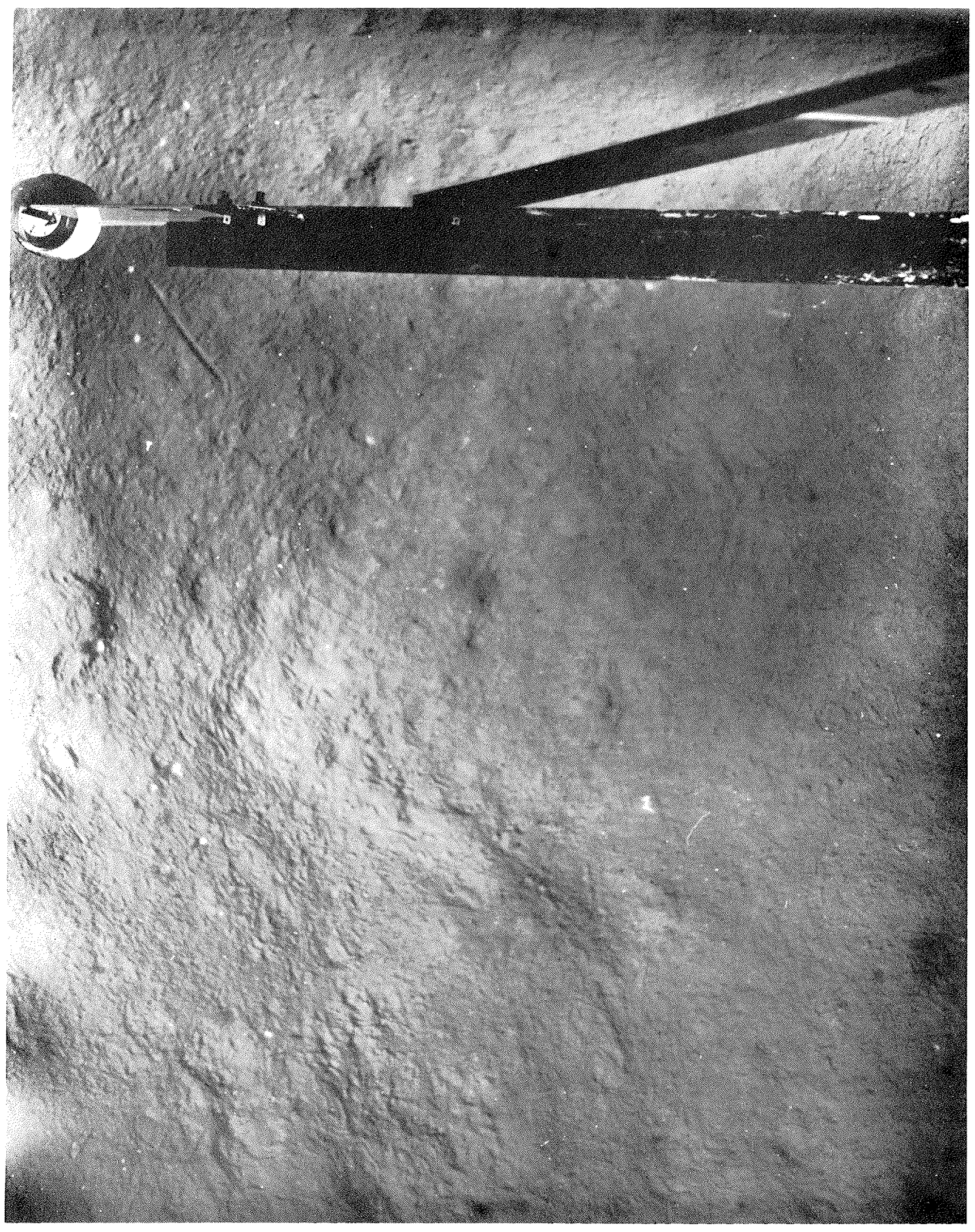


continental slope: smooth sediment, hummocky sediment, talus slopes, and rock outcrops.

The character of the sediment surface is considerably rougher on the lower continental slope than on the upper continental slope, with many large steep-sided depressions and a much coarser surface texture (Fig. 27). Between about 800 meters and 1500 meters water depth, animals and animal tracks are scarce in the bottom photographs. Below 1500 meters the brittle star Ophiomusium lymoni and several species of urchins are abundant. Although distinct tracks are observed in all photographs where these animals are present (Fig. 28), the surface is not covered by their markings. The tracks present in many bottom photographs can be attributed to the animals that are present, suggesting that smoothing of the bottom takes place over a short time scale.

At one photographic station on the lower continental slope (Station 183-4; Fig. 22), the sediment surface was hummocky on a scale of about one meter (Fig. 29). This station is within the 800 to 1500 meter depth zone, and the large burrows and coarse surface texture typical of this zone are superimposed upon the hummocky surface. The hum- 
Figure 27. Photograph from station 59 at 1175 meters on the lower continental slope. Field of view is $1.3 \times 2.0$ meters. Note deep steep-sided depressions, coarse surface texture, and scarcity of animal tracks. 


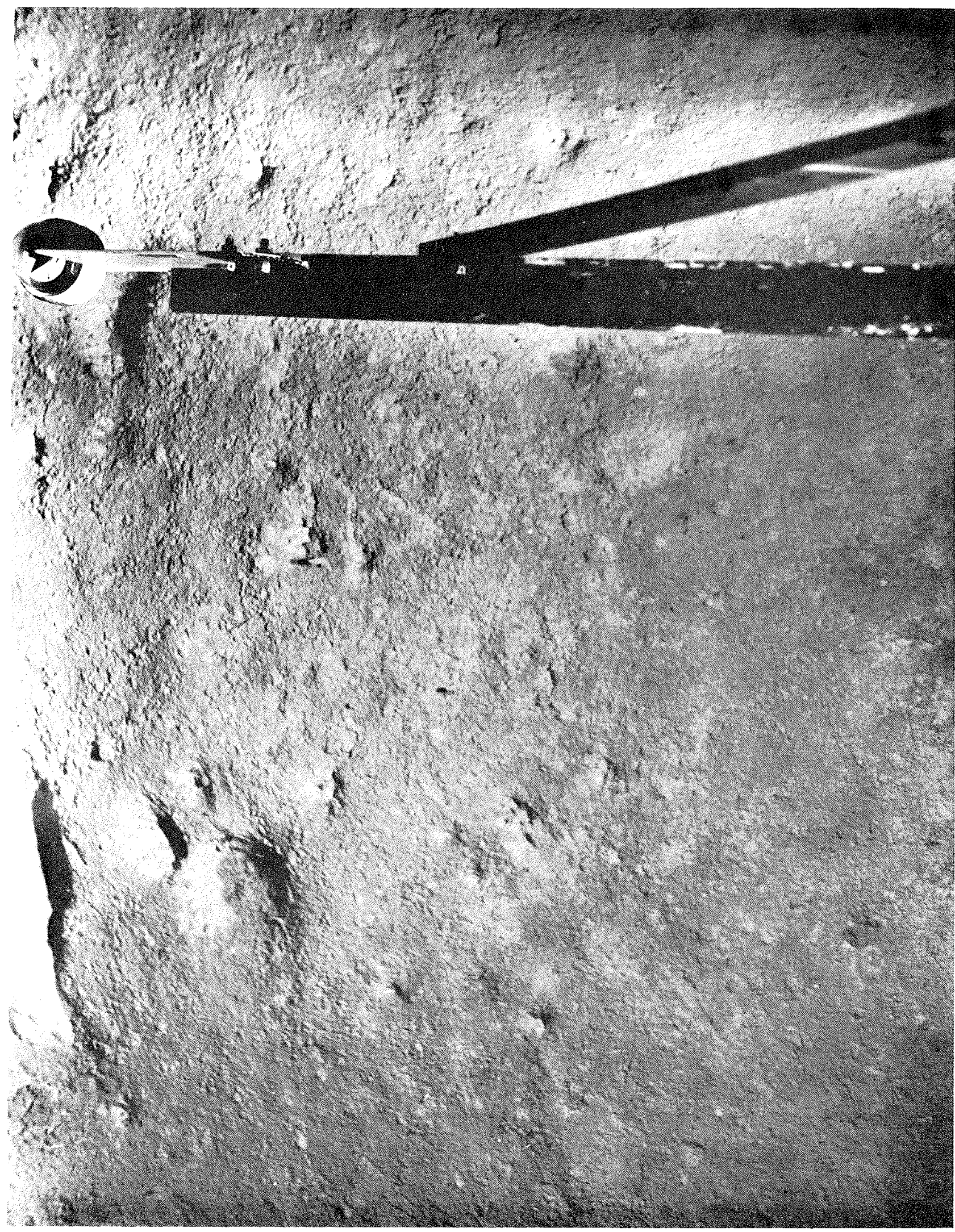


Figure 28. Photograph from station 51 at the base of the lower continental slope, $1790 \mathrm{~m}$ water depth. Location is shown in Figure 22. Field of view is $1.3 \times 2.0$ meters. Note tracks made by epifauna, and relatively smooth surface texture of the sediment. 


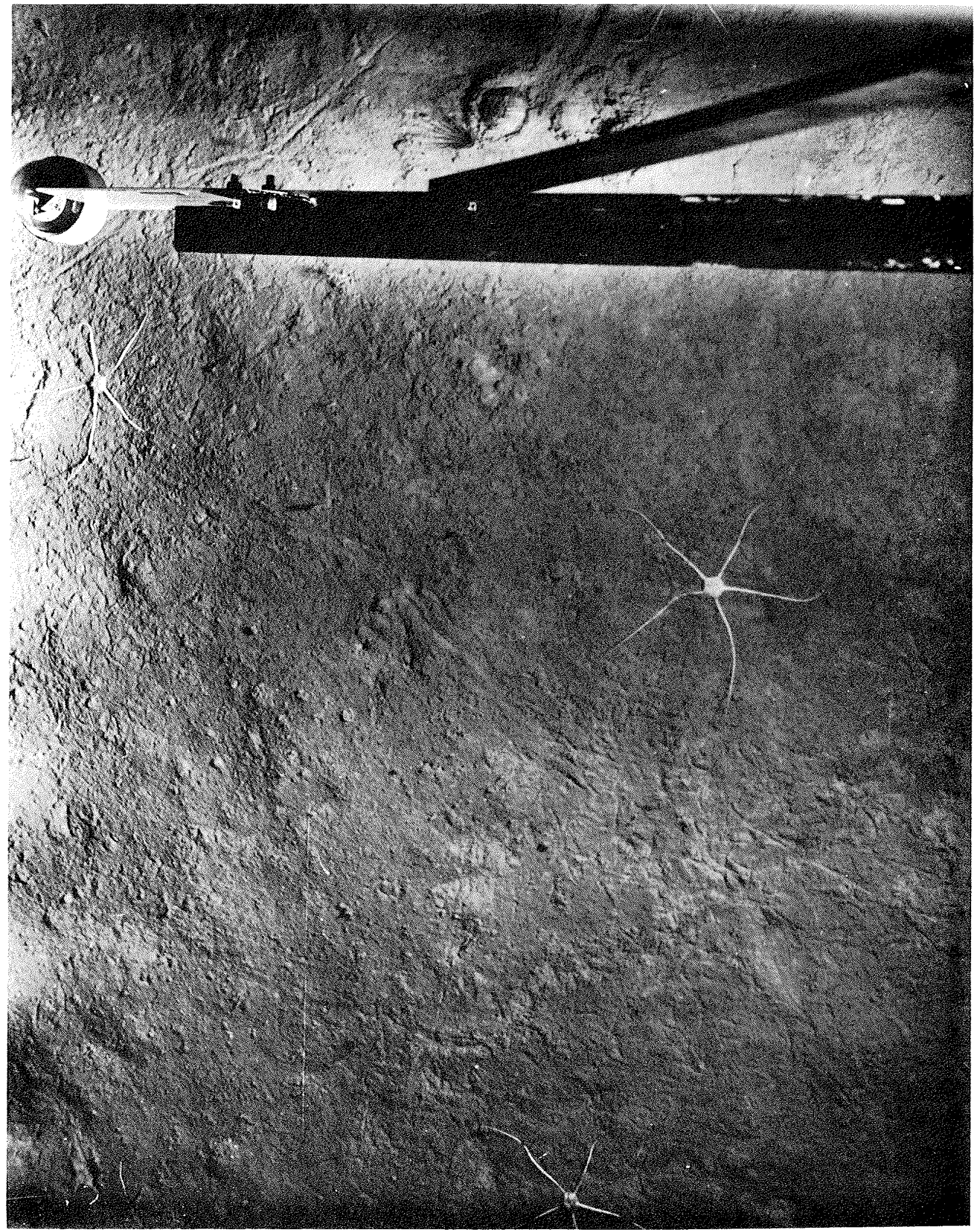


Figure 29. Photograph from station $183-4$ on the lower continental slope, $900 \mathrm{~m}$ water depth. Note hummocky topography. Location is shown in Figure 22. Field of view is approximately $1.3 \times 2.0$ meters. 


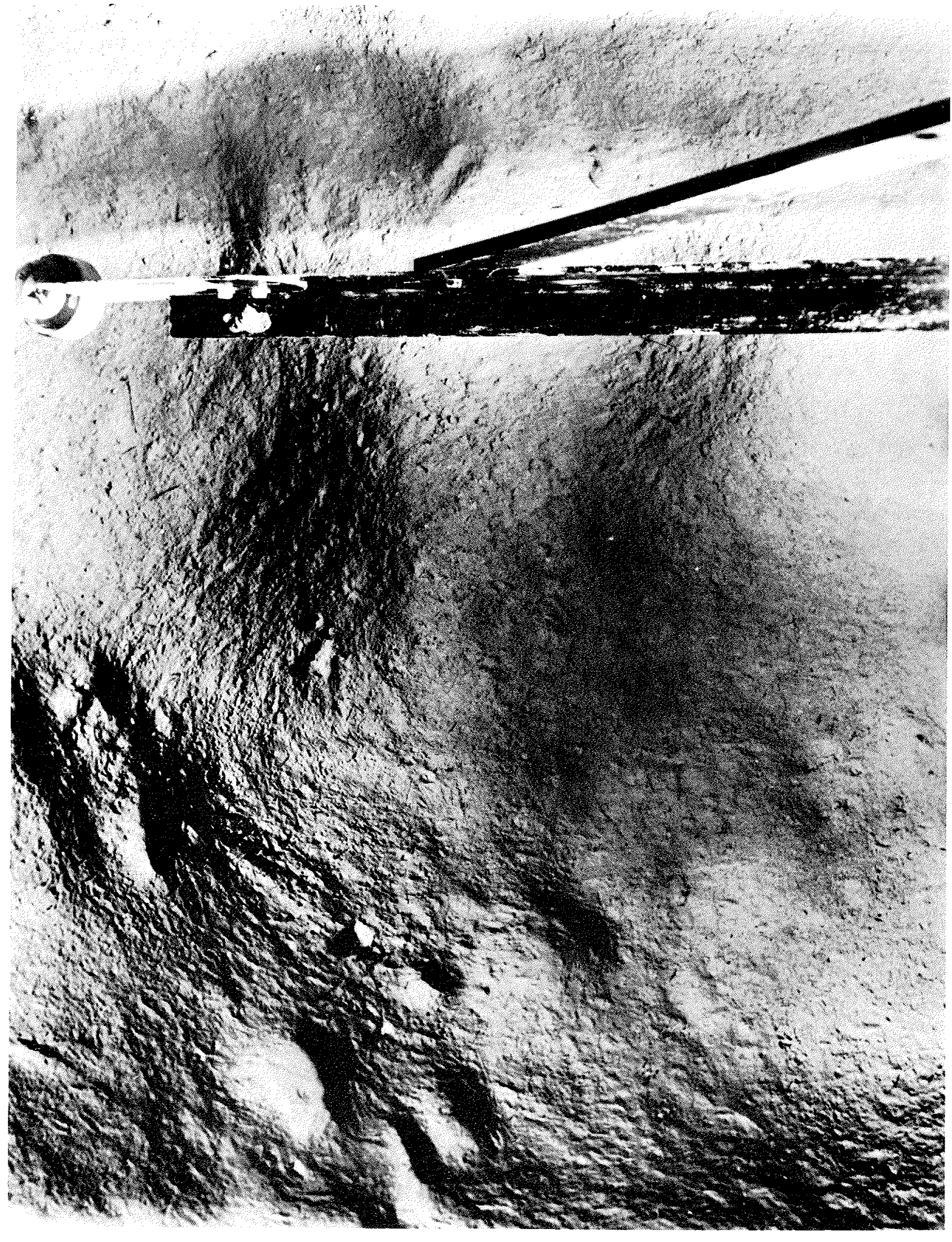

守 
mocks themselves are not caused by biological activity, but probably are formed by mass downslope movement of the upper sediments.

The sediment surface on the lower continental slope is stiff. DRSV ALVIN moves along the bottom on skis, making tracks several centimeters deep. The material from the tracks is piled at the sides as stiff chunks of sediment. Repeated dives at the ALVIN permanent bottom station (Fig. 22) have produced tracks over a period of three years. older tracks are still present, but have been smoothed, suggesting long-term (years) stability of the top few centimeters of sediment, combined with a smoothing process which gradually removes sharp irregularities in the bottom.

At ALCOA SEAPROBE station 6 on the lower continental slope (Fig. 22), four separate rock outcrops were observed and photographed, and many more were evident from the sidelooking sonar reflections. Two bottom types are associated with these features; the rock outcrop itself, and a rubble slope just downslope from the outcrop. The rock outcrops occurred mainly as scarps ranging from about $2 \mathrm{~m}$ to more than $15 \mathrm{~m}$ in height (Fig. 30), and consisted of apparently 
Figure 30. Composite photograph of an outcrop on the lower continental slope, at station AS-6. For scale, the brittle star Ophiomusi um Iymoni, visible on the sediment surface at right has an average arm-span of 18 to $20 \mathrm{~cm}$, arm-tip to arm-tip. 


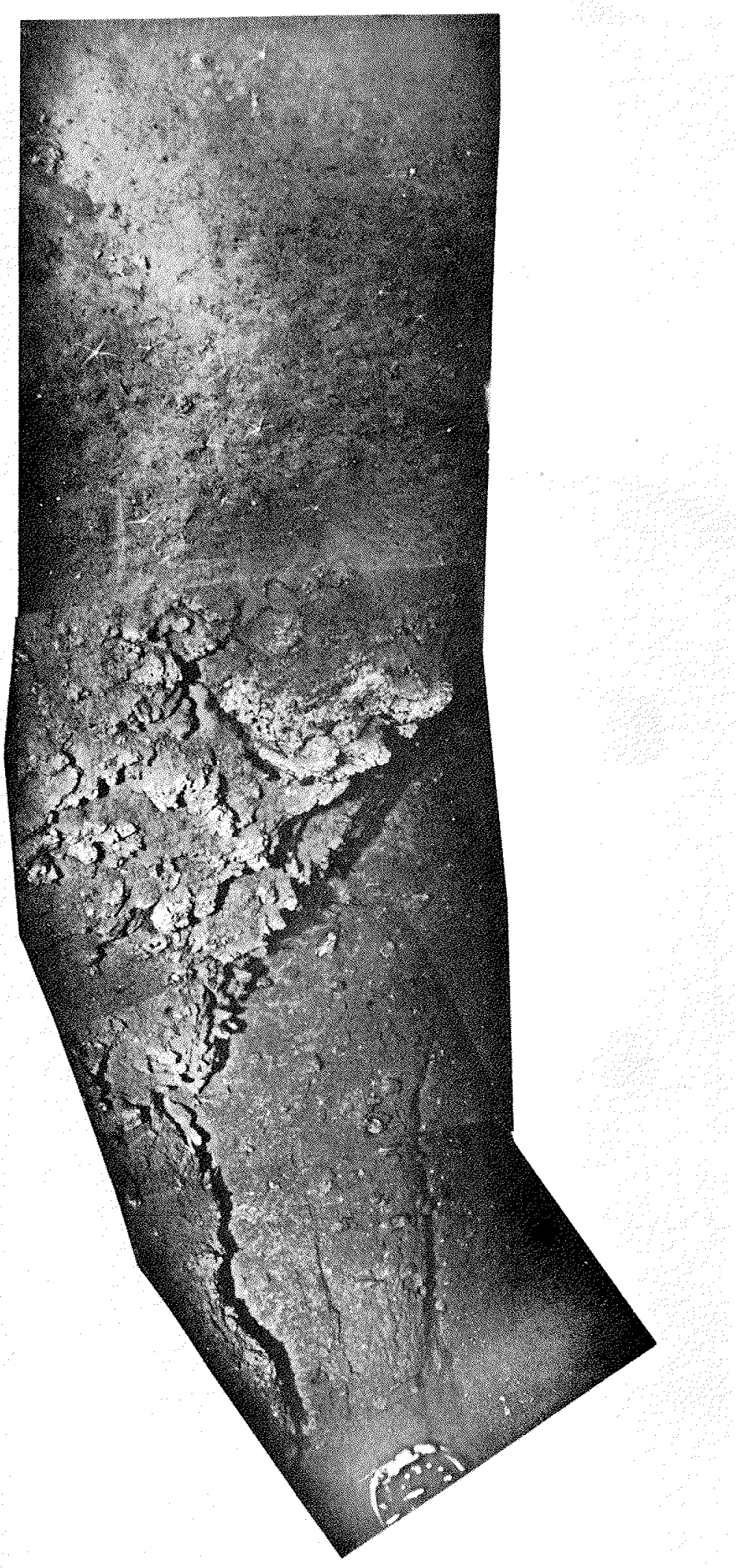

Figure 30. 
semiconsolidated to well indurated sedimentary rocks. Where bedding was observed it was apparently nearly horizontal. On one scarp, unconsolidated sediment covered the upper surface (Fig. 30). On another, the surface at the top of the scarp consisted of a rock surface nearly devoid of sediment for more than 100 meters beyond the scarp (Fig. 31)

The orientation of the scarps could not be determined directly, due to problems with the compasses on the ALCOA SEAPROBE instrument package, but an approximate downslope-facing orientation is inferred from a knowledge of the ship's direction of drift over the bottom combined with television monitoring. Below each of the scarps was as extensive rubble slope consisting of pieces of outcrop rock of various sizes and unconsolidated sediment (Fig. 31)

The DSRV ALVIN permanent deep bottom station (Fig. 22) was located beside a similar scarp feature. Several dives of DSRV ALVIN on the bottom station entered the scarp area. Unfortunately, no geologists were aboard the submersible during any of these dives, and the information used to draw figure 32 is based on observations by pilots and biolo- 
Figure 31. Scarp on lower continental slope, station AS-6, observed from directly above. Note bare rock on upper surface and rubble slope below the outcrop. Television monitoring indicated the height of this scarp to be approximately 2 meters. Ophiomusium lymoni brittle stars have an average armspan of 18 to $20 \mathrm{~cm}$. 


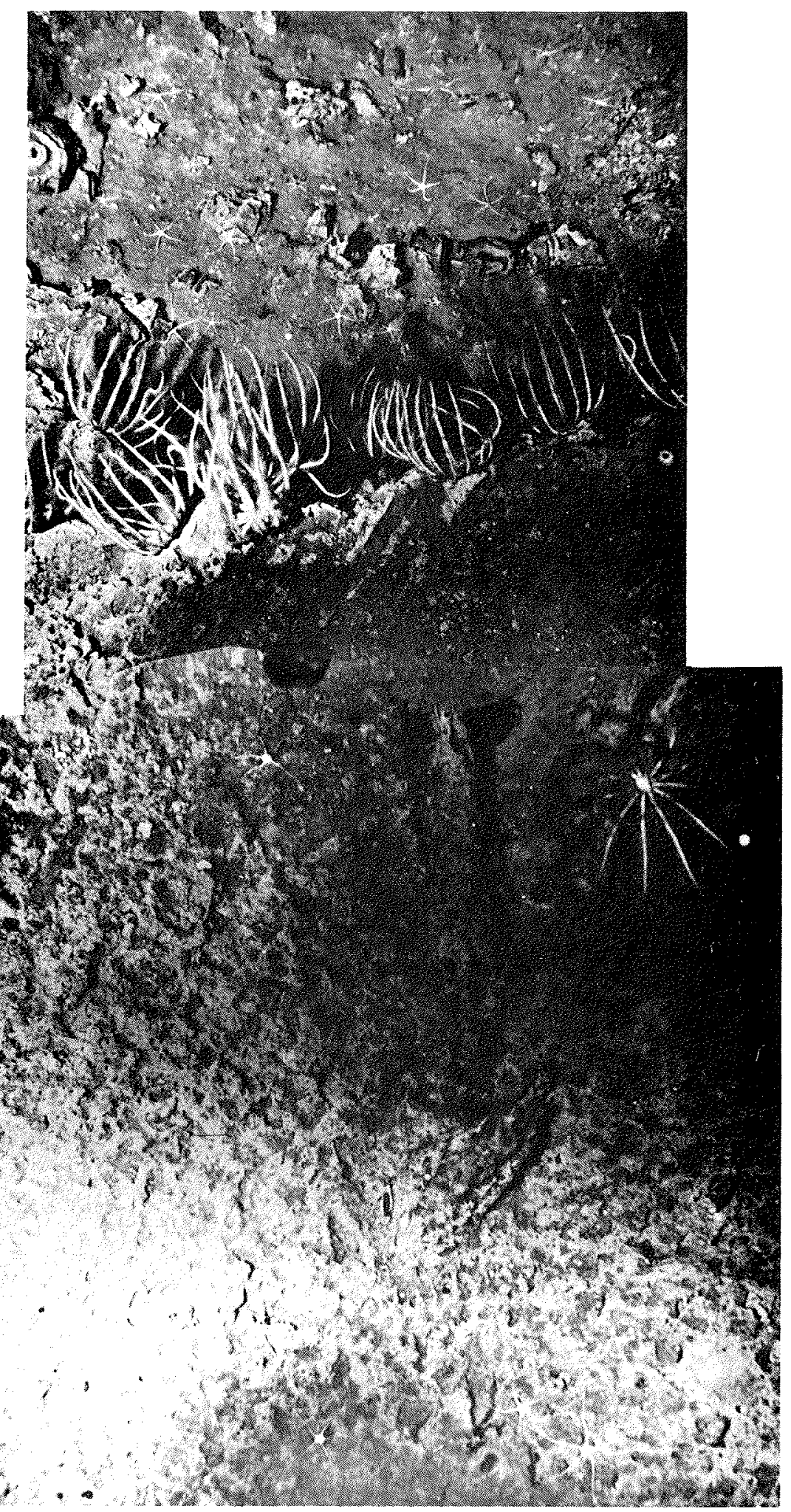

Figure 31. 
Figure 32. Drawing of bottom feature at the permanent deep bottom station compiled from drawings and accounts of pilots and scientists. The scar is approximately $100 \mathrm{~m}$ long, 50 meters across at the mouth, with horizontally bedded scarps, rubble slopes composed of mixtures of unconsolidated sediment and fragments of sedimentary rock derived from the outcrop, and a slight hump across the mouth of the feature. 


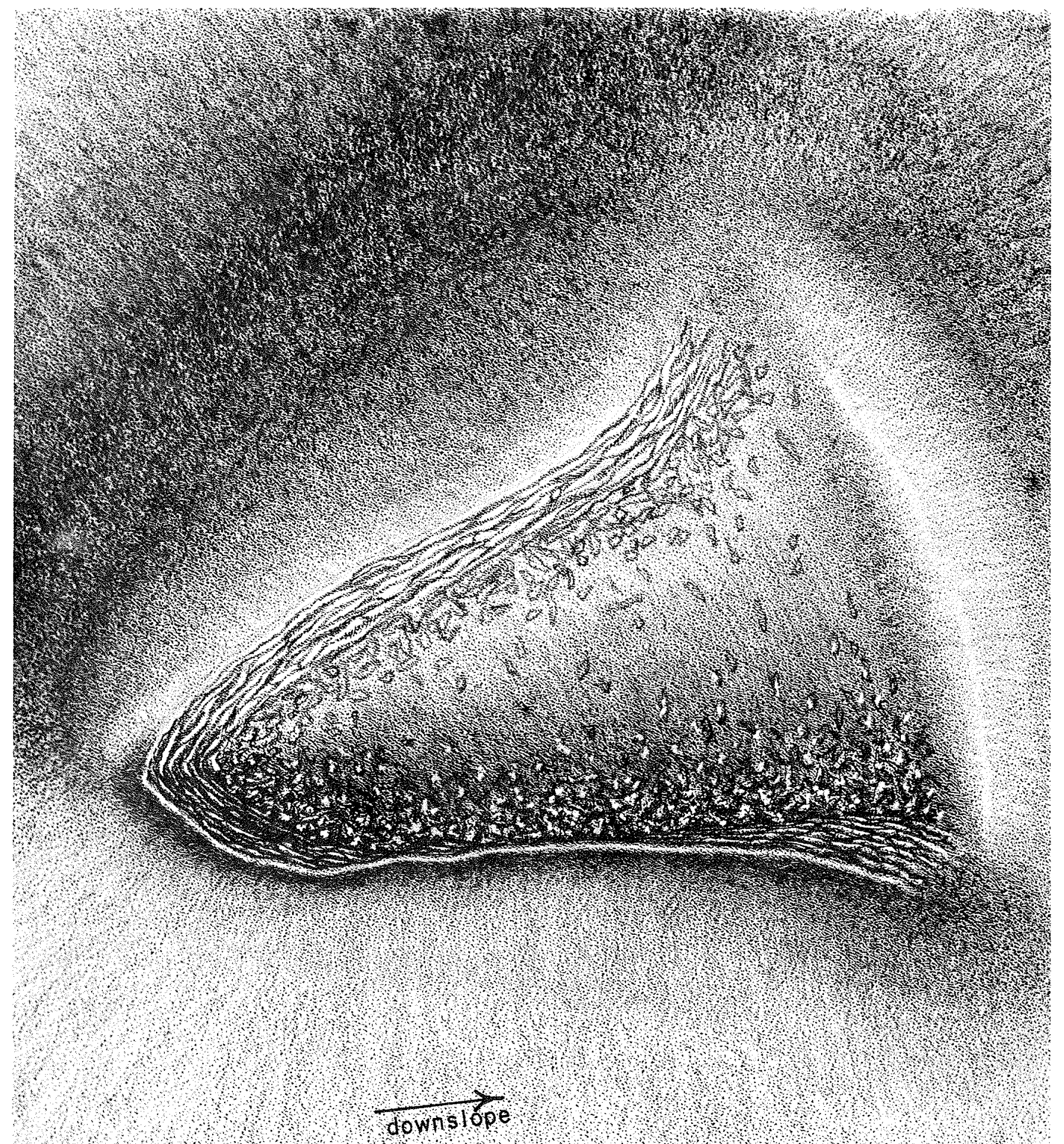


gists. Its form suggests that the feature is a scar left from downslope slumping of the surficial layers of sediment. One rock was recovered from this outcrop. It is a glauconitic sandstone. It is devoid of fossils, but judging from the friable nature of the material, it is probably Pleistocene in age.

The surface of the upper continental rise was photographed in one station within the study area (Gosnold station 191-1, Fig. 22) at 2180 meters depth and at one station just south of the study area. At both stations the bottom was markedly heterogeneous over the kilometer of ship drift during photography. Where the bottom is covered by sediment it is smooth and soft in appearance. Current lineations trending southeast-northwest and scour on the southeast side of one cobble indicate currents from downslope (Fig. 33).

Patches of cobbles are observed in photographs at the rise stations (Fig. 34). Bottom dredging in this area recovered many pebbles and cobbles of crystalline rocks, apparently glacial erratics. In general, many more pebbles and cobbles were photographed at the two rise stations than at any location on the continental slope except at rock 
Figure 33. Photograph from station $191-1$ at $2160 \mathrm{~m}$ water depth on the upper continental rise. Note smooth bottom, current lineation, and scour around cobble in lower left. Field of view is approximately $1.3 \times 2.0$ meters. 




$\dot{m}$
$\frac{0}{5}$
$\frac{\sigma}{\square}$ 
Figure 34. Cobble patch at station 191-1 on the upper continental rise. Suspended sediment is due to disturbance of the bottom by the camera. Field of view is approximately $1.3 \times 2.0$ meters. 


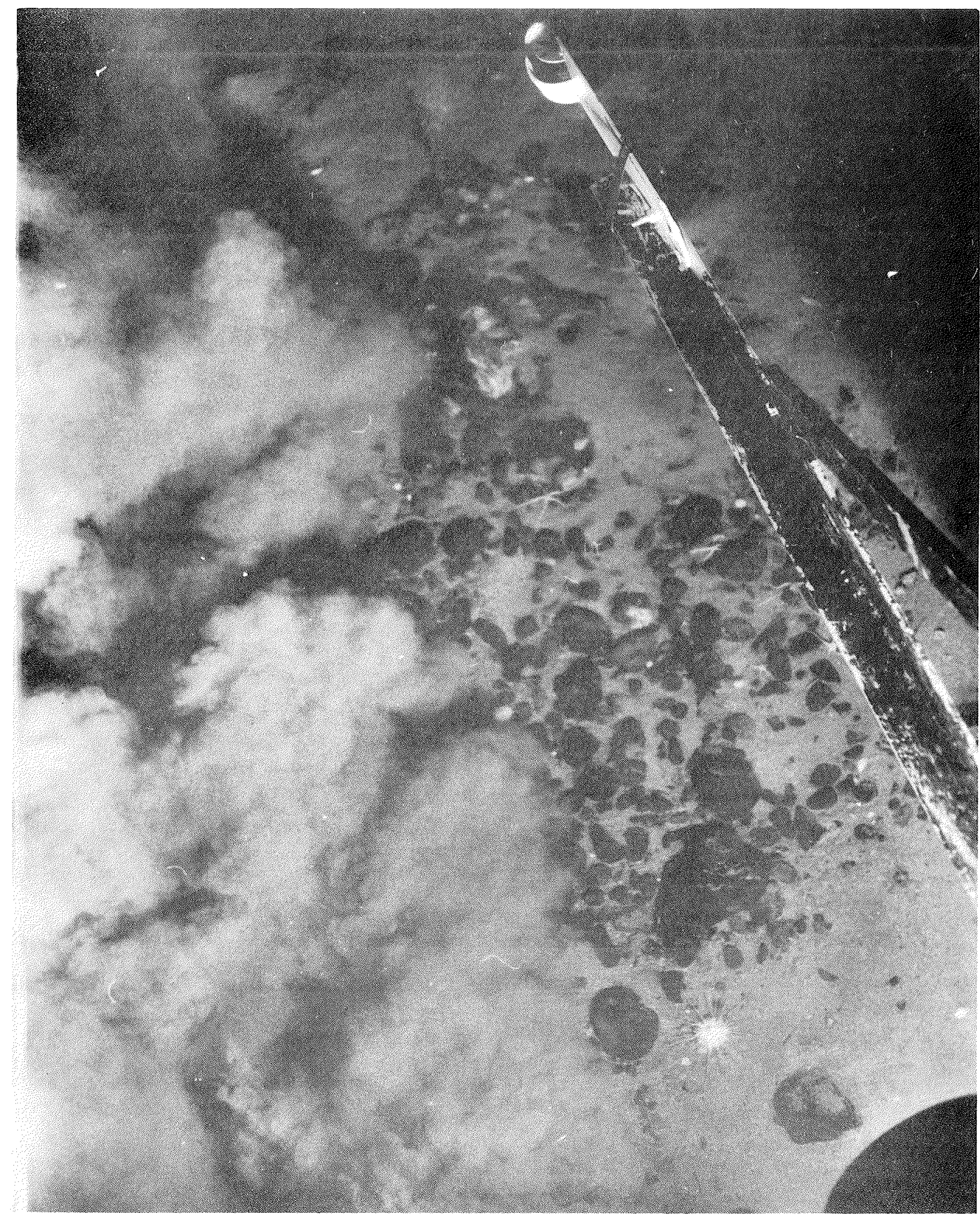

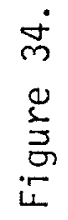


outcrops. Observations from DSRV ALVIN dives at the base of the continental slope indicated that surficial rocks are present outside the outcrop area of the deep bottom station at an areal frequency on the order of one rock per $10^{3}$ to $10^{5} \mathrm{~m}^{2}$. Judging from the photographs from the uppermost continental rise, the areal frequency of rocks on the surface of the continental rise near the base of the continental slope must be about two to four orders of magnitude greater than the frequency on the lower continental slope.

Laboratory flume experiments

Two relatively undisturbed sediment samples were obtained by DSRV ALVIN on dive number 437 at the deep bottom station using modified Birge-Ekman box corers (Rowe and Clifford, 1973). The corers were gently lowered into the sediment by ALVIN's articulating arm while the submersible sat stationary on the bottom, the water in the corer escaping via a one-way valve in the top. The samples recovered in this manner measured $15 \mathrm{~cm}$ x $15 \mathrm{~cm}$ by about $10 \mathrm{~cm}$ deep, and had an essentially undisturbed surface, in some cases retaining delicate ophiroid tracks. The samples were extruded into plastic-lined plywood 
boxes with a dampened paper towel covering the surface. They were sealed and stored at close to ambient bottomstation temperatures until the experiment, a total of two weeks. The "undisturbed" nature of the sediment samples is obviously not perfect. Sampling, storage, transportation, two transfers between containers, and changes in temperature, all may have altered the physical characteristics of the sediment surface. However, the samples are considered to be more representative of the deep-sea sediment surface than "resedimented" samples, in which all internal structure has been disrupted.

In the laboratory, the samples were transferred with minimal disturbance to a metal tray, the sediment surface being just even with the top of the tray. The tray was placed in a recirculating and tilting open Plexiglass channel 6 meters long and $17 \mathrm{~cm}$ wide, false bottoms were adjusted level with the sediment surface, and the flume was filled with filtered sea water to a depth of $6 \mathrm{~cm}$ above the false bottom. The flow velocity of water (measured by timing surface floats) was gradually increased and the response of the bed was observed (Table 2).

Several differences between the environments of the 


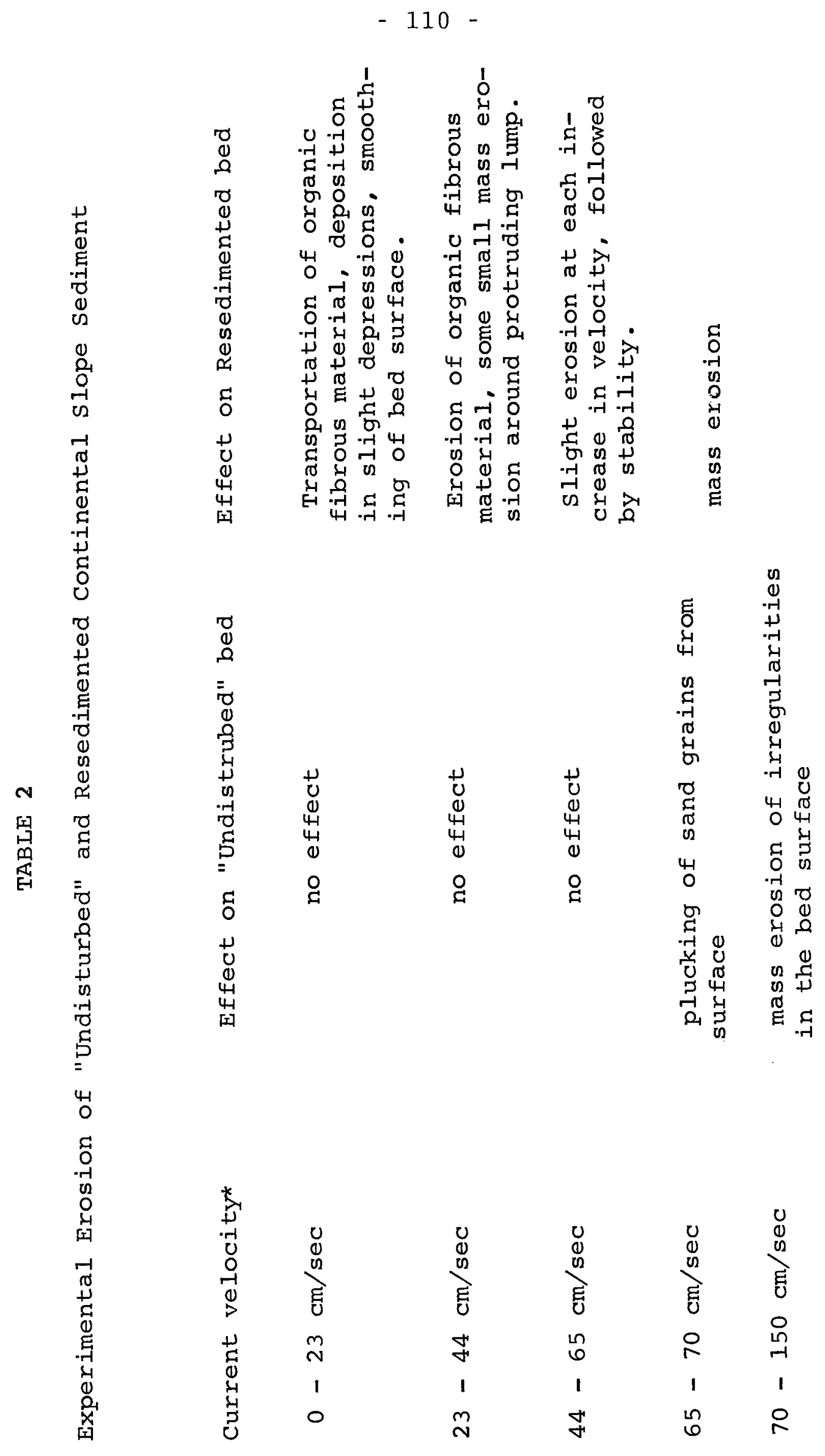

$u$
$x$
0
+
0
0
0
$*$ 
flume and of the continental slope present difficulties in comparing the velocities of flow measured in the flume to deea-sea measurements. The differences in water temperature and flow depth can easily be compensated if the basic flow conditions are similar in the two situations. Assuming that both flows are hydrodynamically smooth (that is, the roughness elements of the bed are smaller than the thickness of the laminar sub-layer along the boundary) the flume velocities can be multiplied by a factor of 1.75 to approximate the velocities which would produce the same bed shear stress if measured at deep-sea temperatures one meter above the bottom (Southard and others, 1971).

Although the flow within the flume is probably hydrodynamically smooth, at least over the false bottom, the deep-sea floor is likely to be hydrodynamically transitional between smooth and rough (Sternberg, 1970). When the flow is rough, the height and spacing of the roughness elements will alter the correction factor which must be applied to the flume velocities. These factors are difficult to predict, but assuming fully developed rough flow on the continental slope, and fully smooth flow in the flume, the velocity measured in the flume would approximate 
the analogous velocity measured $1 \mathrm{~m}$ above the bottom on the continental slope.

Due to difficulties in determining the roughness characteristics of the bottom (both in the flume and in the deep-sea), and the probability that flow under most circumstances is more nearly smooth than rough, the correction factor of 1.75 was used in this study and the values reported in Table 2 and in the text are the flume velocities multiplied by 1.75 .

At velocities less than $65 \mathrm{~cm} / \mathrm{second}(37 \mathrm{~cm} / \mathrm{second}$ measured at the surface in the flume), no effect on the bed could be detected, but occasional loose sand grains were rolled along the bottom. At about $65 \mathrm{~cm} / \mathrm{second}$, sand grains which were only partially embedded in the finegrained sediment were plucked out and rolled downstream by the current. One sample was left under a $70 \mathrm{~cm} / \mathrm{sec}$ current for one hour, with no noticeable change in the sediment surface after the initial plucking of partially embedded sand grains.

Velocities greater than $70 \mathrm{~cm} / \mathrm{sec}$ caused some mass erosion of the surface, breaking off small chunks of sediment at minor surface irregularities in the bed, produc- 
ing an upstream-facing scarp which very gradually worked its way downstream. Even after a half hour at $150 \mathrm{~cm} / \mathrm{sec}$ the flat portions of the sediment surface were undisturbed. One of the samples was resedimented after the initial tests. It was mixed into a thick slurry and allowed to settle for twenty hours. The bed surface had an appearance similar to the "undisturbed" sediment samples, except that a surficial deposit of loose, fibrous, organic-appearing material was present on the resedimented bed. I observed the same type of material on an ALVIN dive at the deep bottom station, where it was transported across the bottom by weak currents.

In the flume run this material moved freely at low velocities. The flume was left at $23 \mathrm{~cm} / \mathrm{sec}$ for one-half hour. At this velocity the transported material filled small irregularities in the bed and tended to smooth the bed surface. At $31 \mathrm{~cm} / \mathrm{sec}$ slight scour was observed around one relatively consolidated portion of the bed which protruded about $5 \mathrm{~mm}$ above the surrounding bed surface. After 15 minutes at $31 \mathrm{~cm} / \mathrm{sec}$ the scour moat was $2 \mathrm{~mm}$ deep. At $36 \mathrm{~cm} / \mathrm{sec}$ the fibrous material previously deposited in bed depressions was eroded. At $44 \mathrm{~cm} / \mathrm{sec}$ possible incipient 
erosion of the planar portion of the bed was observed. Definite erosion was observed at $53 \mathrm{~cm} / \mathrm{sec}$. After initial erosion at a given setting the bed would become stable within a few tens of seconds and erosion ceased. Mass erosion of the bed at slight irregularities was observed at $65 \mathrm{~cm} / \mathrm{sec}$.

\section{CHARACTERISTICS OF SURFACE SEDIMENTS}

\section{Introduction}

Forty-six surface sediment samples were analyzed (Fig. 35). About half were collected during the joint Woods Hole Oceanographic Institution - U.S. Geological Survey sampling program of 1962-1970 and consist of largevolume Campbell grab samples and tops of short open-barrel cores. The remaing twenty samples were collected by openbarrel coring on the cruises outlined in Table 1.

Laboratory analyses for texture and composition fol-

lowed standard procedures for the most part. Samples were split at $62 \mu \mathrm{m}$ and $2 \mu \mathrm{m}$. The resulting size fractions were analyzed as summerized in Table 3.

\section{Size analysis}

Contours of percent sand, silt, and clay generally parallel bathymetric contours (Fig. 36). A band of sand 
Figure 35. Positions of sediment samples analyzed in this study. Filled circles represent surface samples. Open circles represent cores. Cores labeled PC are piston cores, all others are open-barrel. 


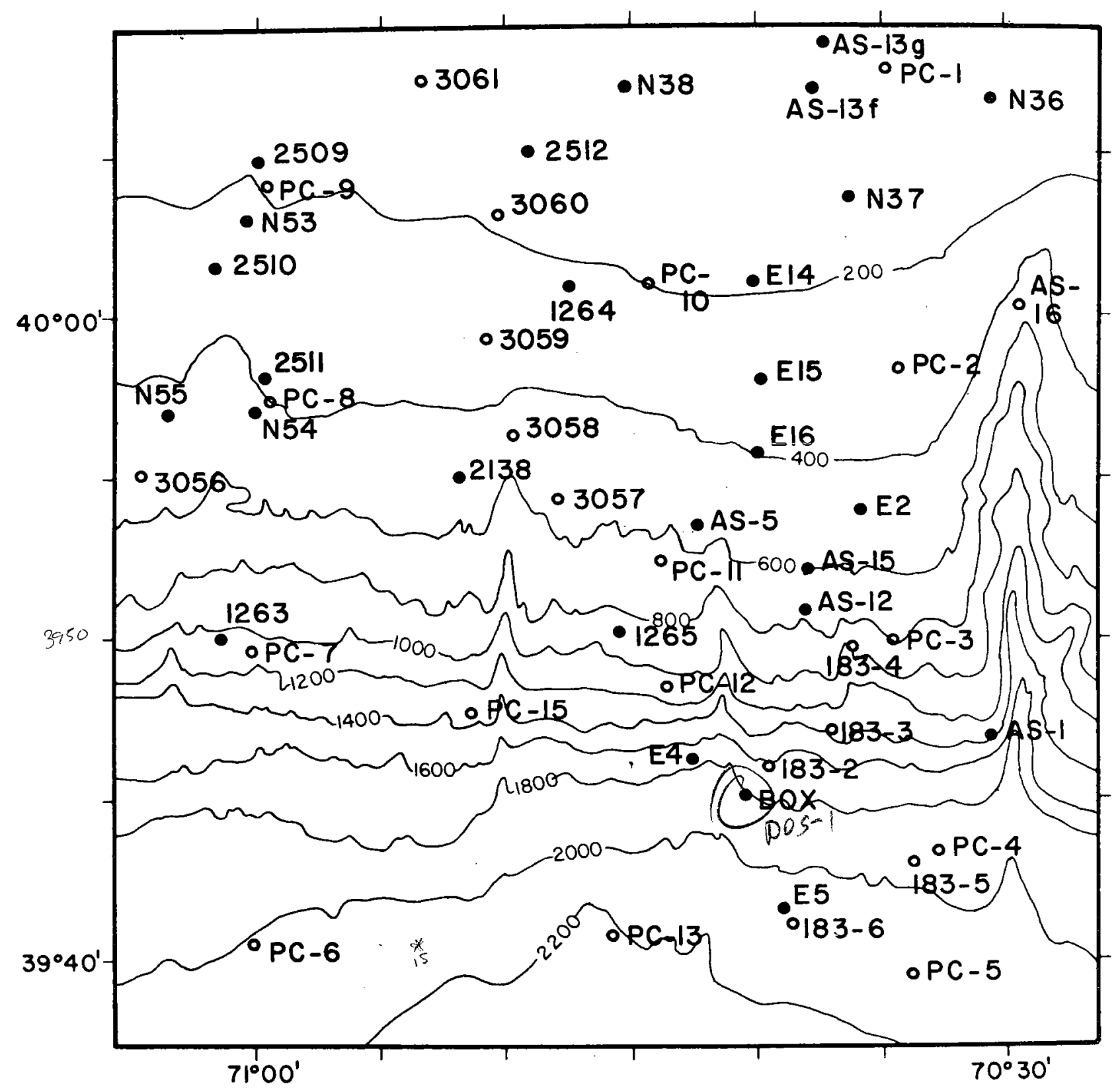

Figure 35. 
Figure 36. Textural composition of surface sediments.
a. Percent sand
b. Percent silt
c. Percent clay
d. Modes of U.S. Geological Survey - Woods Hole Oceanographic Institution samples, in order of decreasing strength in bimodal samples. Data from Hathaway, 1971. Values given in $\phi$ units $\left(\phi=-\log _{2} \mathrm{~mm}\right)$. 

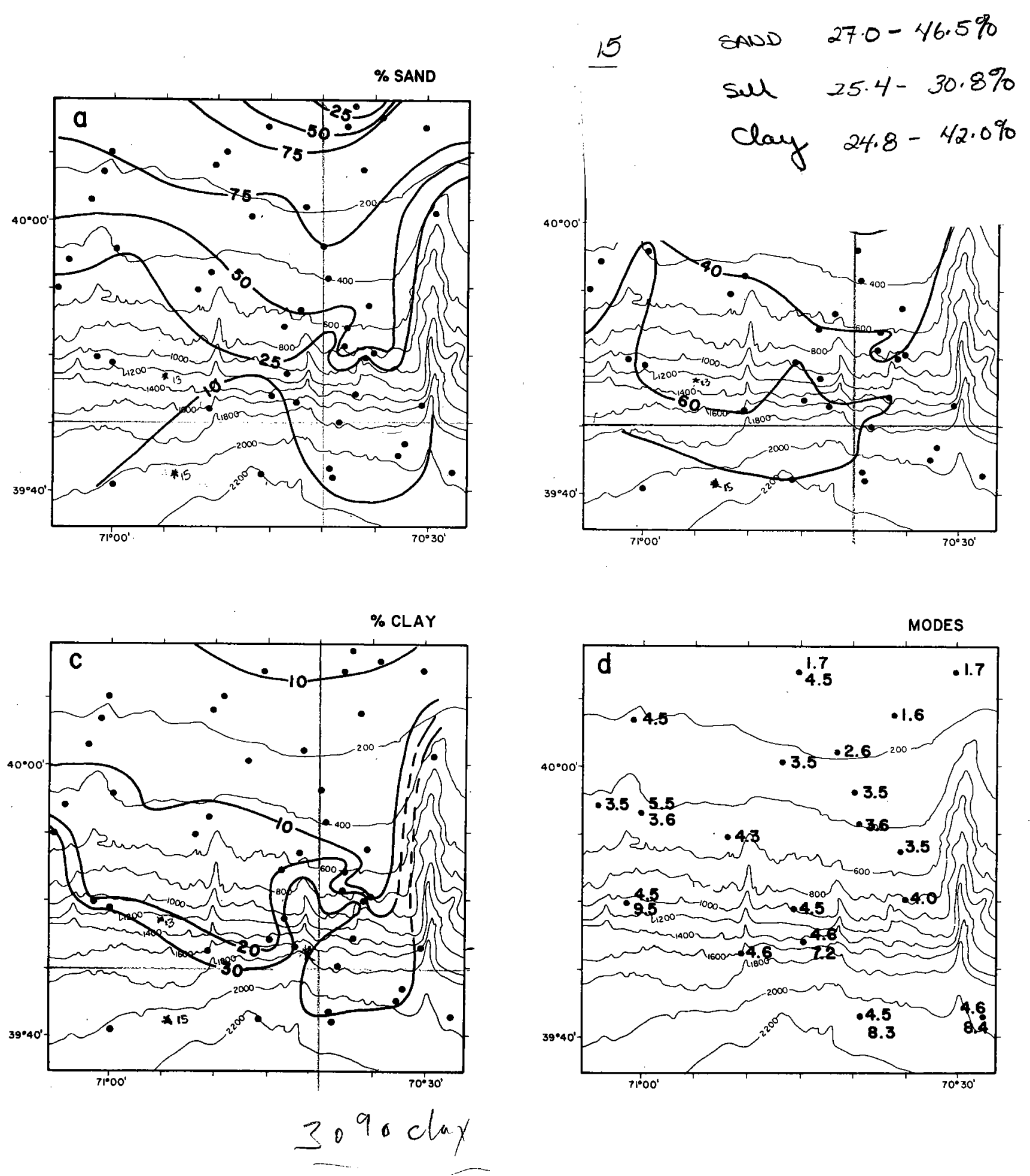

Figure 36. 
occurs at the shelf break, with decreasing sand content both landward and seaward. Silt content generally complements the sand content, with increasing percentages of silt landward and seaward of the shelf break. The clay content is low over most of the continental slope but increases near the base of the lower continental slope to more than $30 \%$. Smaller variations are superimposed on the general textural pattern on the lower continental slope in the eastern half of the study area, possibly because of the relatively high density of the samples. The percentage contours are more irregular, with high clay values extending downslope. The samples from Alvin Canyon are finer grained than adjacent slope samples.

Plots of percentages of sand, silt, and clay vs. depth show high scatter at shallow depths, with much less scatter below 1000 meters (Fig. 37), but the trend toward finer sizes with increasing depth is apparent. Four grain-size populations occur in the area, which are apparent on a sand-silt-clay triangular plot of the data (Fig. 37). The few samples from the outer shelf are highly variable in grain size. Samples from the shelf-break and the lower continental slope cluster tightly in the sand and clayey silt ranges, respectively. Samples from the upper con- 
Figure 37. Plots of sand, silt, and clay content of surface sediments versus depth of the sample and a triangular plot of the textural data. Symbols on triangular plot are representative of depth: stars $=120-130 \mathrm{~m}$; open circles $=$ 130-180 m; filled circles $=200-1000 \mathrm{~m} ;$ squares $=1000-2000 \mathrm{~m}$. 

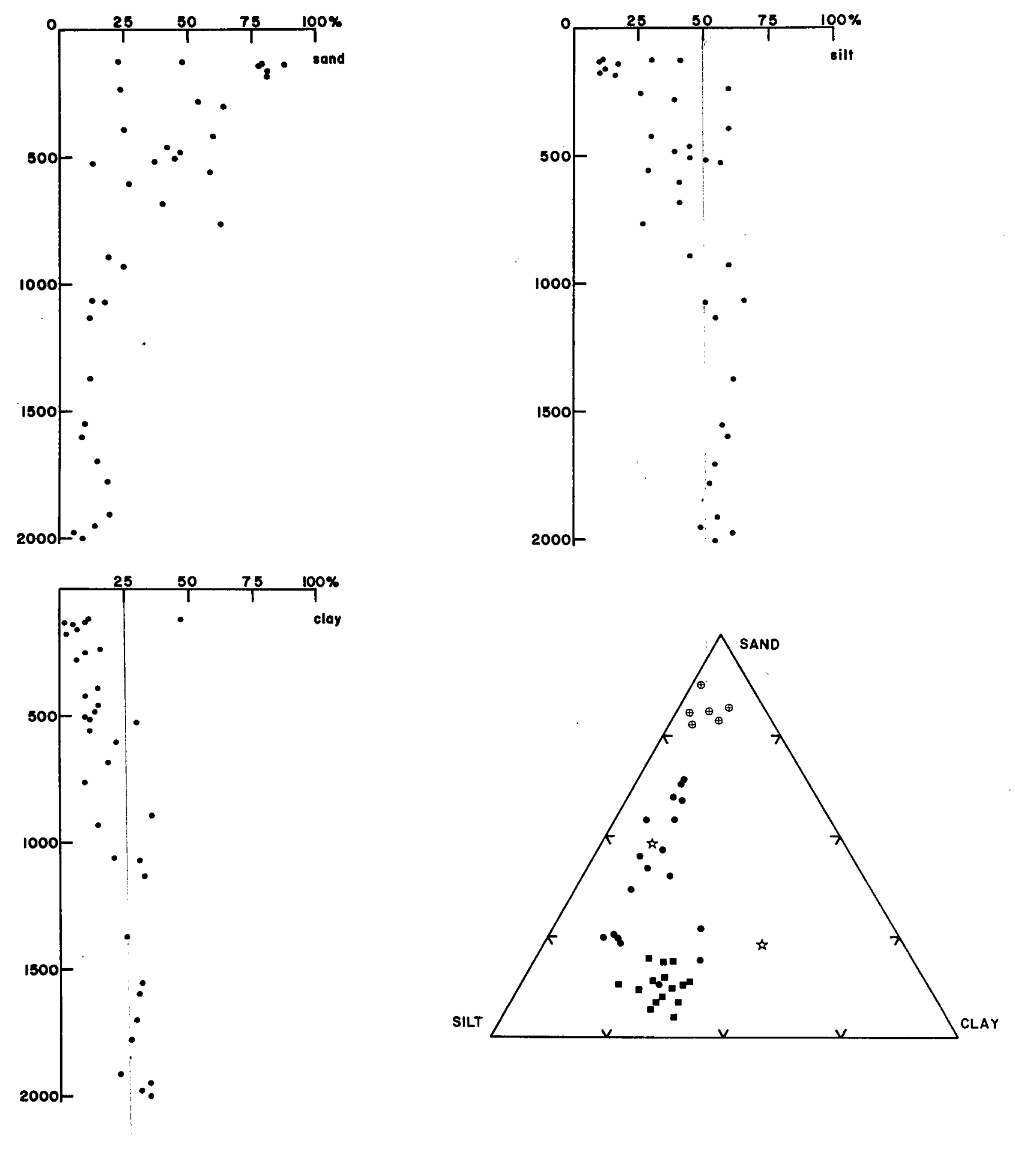

Figure 37. 
tinental slope have a broader grain-size range in the intermediate silty sand and sandy silt classes. Plots of the modes of the U.S.G.S. - W.H.O.I. grab samples (Fig. 36) show coarse modes restricted to the outer continental shelf, two distinct intermediate modes on the upper and lower continental slope, and fine modes on the upper continental rise. Composition of the sand fraction

The sand fraction is dominated by colorless clear mineral grains (quartz and feldspar) and by foraminiferal tests (Fig. 38). A third major component* is present in samples from the lower continental slope, consisting of sand-sized grains of semi-consolidated fine-grained sedimentary rock. The quantitative distribution of sedimentary rock fragments is difficult to determine because the grains are partially disaggregated during initial laboratory treatment. They occur in all but two of the samples from the lower continental slope and upper continental rise, in concentrations of up to $30 \%$ of the sand fraction. The percentage of clear mineral grains decreases down

* components in concentrations greater than about $10 \%$ of a size fraction are termed "major components" all others are "minor components." 
Figure 38. Composition of the sand fraction ( $>62 u m$ ) of the surface sediment, in frequency percent. Determined by binocular microscopic examination of the entire sand fraction (Table 3).

a. Clear mineral grains, mainly quartz and feldspars.

b. Foraminifera tests. c. Mica flakes. d. Glauconite grains. 

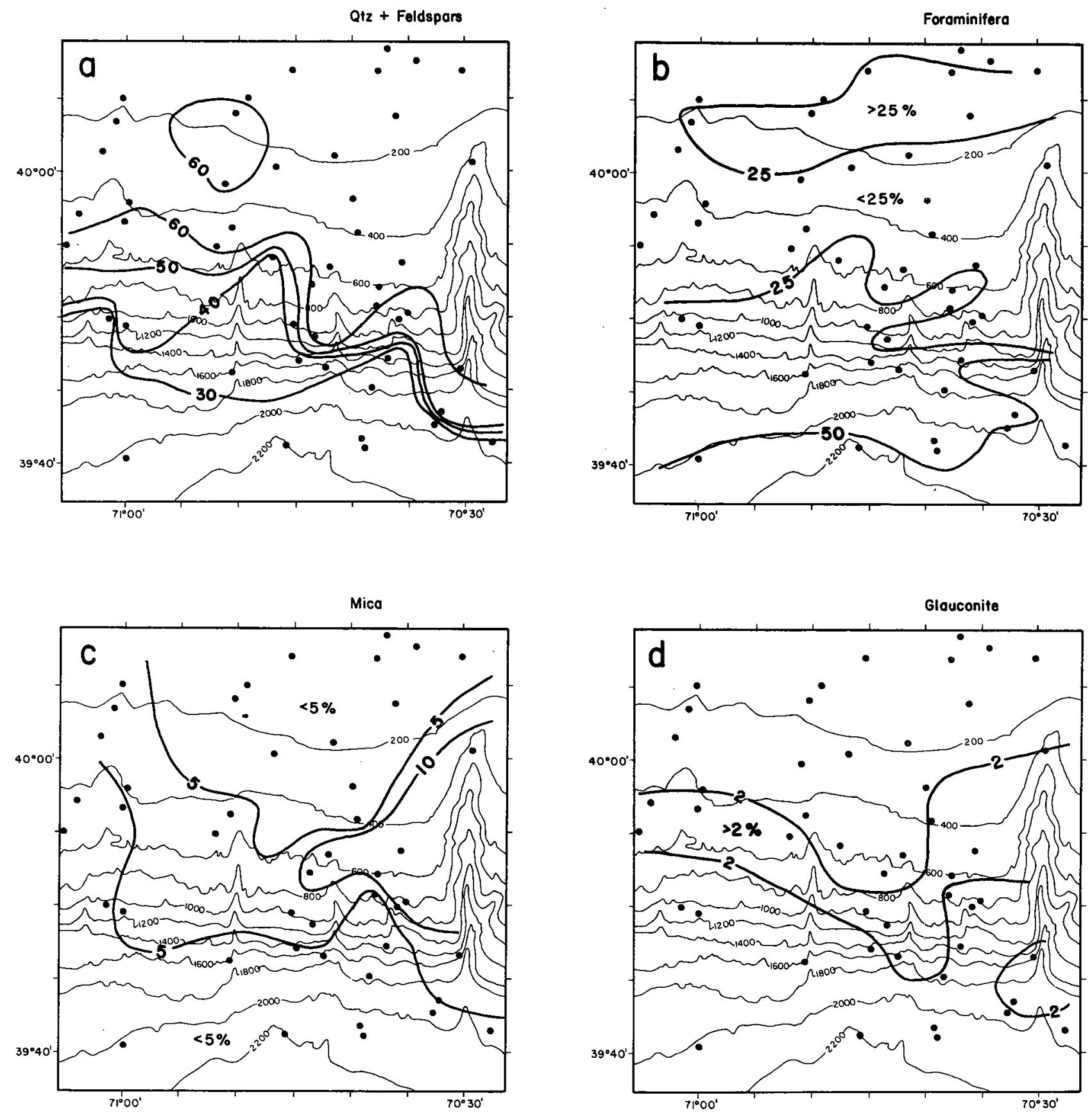

Figure 38. 
the lower continental slope, and the percentage of foraminiferal tests increases. Two minor components, mica and glauconite, appear to occur in a band across the area near the transition from upper continental slope to lower continental slope.

The calcium carbonate component of the sand fraction (Fig. 39) is dominated in deep water by planktonic Foraminifera. The smaller carbonate contribution to the sediments in shallower depths is mainly the tests of benthonic Foraminifera. Although these tests are numerically abundant, they contribute much less calcite to the sediment than planktonic forms because in shallow depths species of much smaller sized individuals and species with arenaceaus tests are dominant.

A third major carbonate component consists of fragments of calcareous Foraminiferal tests. These are distinct from whole tests or slightly fragmented tests, and seem to form a separate sand component. Fragments occur in greatest abundance on the upper continental slope, with a distribution similar to mica and glauconite. No species determinations were possible because of the highly abraded and fragmented nature of the tests, but the tests are 
Figure 39. a. $\mathrm{CaCO}_{3}$ content of sand fraction, in weight percent.

b.-d Composition of carbonate fraction of surface sands, in frequency percent of the carbonate fraction.

b. Planktonic foraminifera, percent of the carbonate fraction.

c. Benthonic foraminifera, percent of the carbonate fraction.

d. Fragments of calcareous tests, percent of the carbonate fraction. 

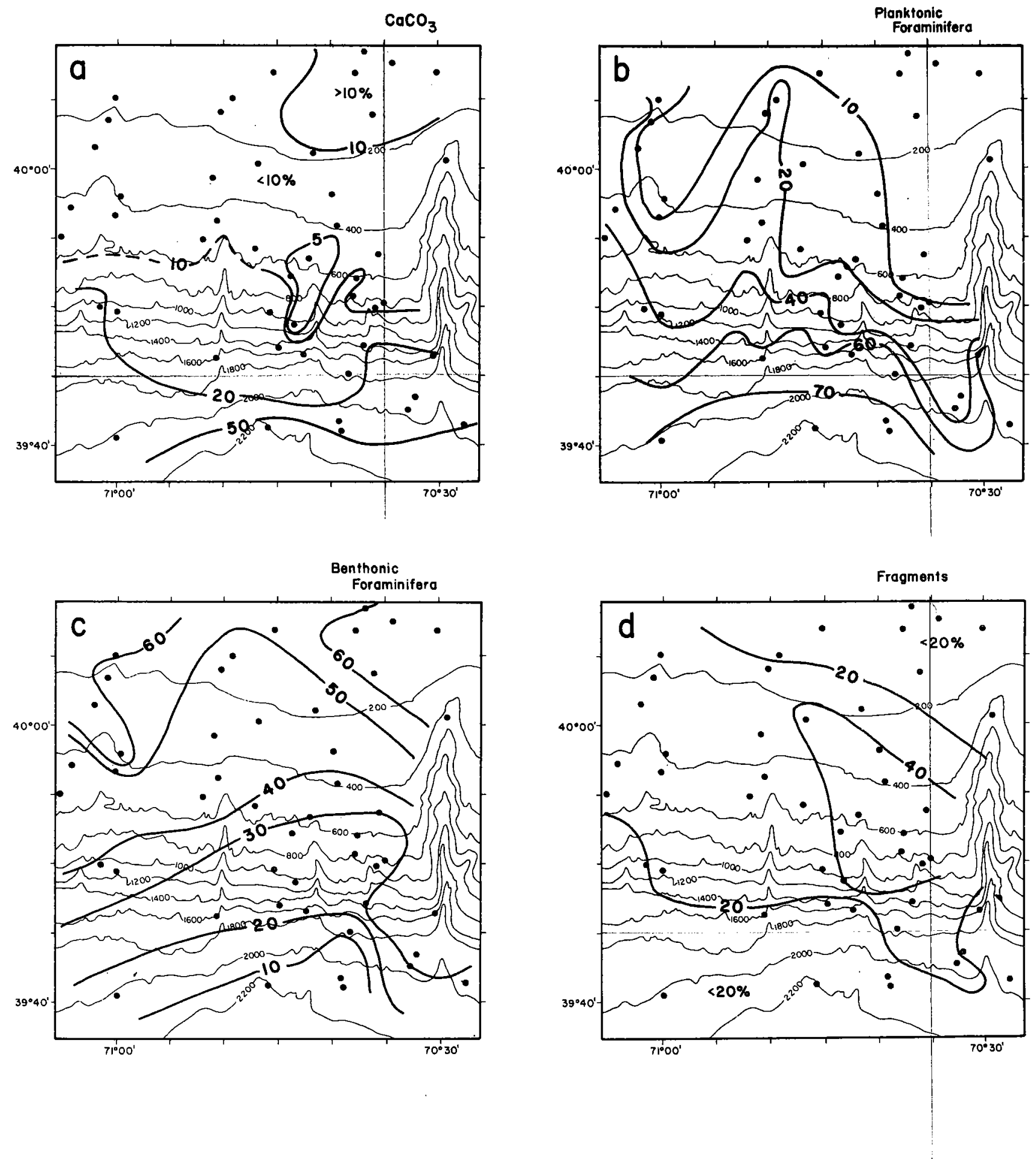

Figure 39. 
predominantly of planktonic form.

Heavy minerals were analyzed by a combination of $\mathrm{x}-$ ray diffraction and Q-mode factor analysis (MacIlvaine and Ross, 1973). The result of this type of analysis is a matrix in which the composition of each sample is represented as a micture of several "end member" compositions which approximate actual samples. For example, a mixture of heavy minerals similar to the composition of the sample represented by a star in figure $40 \mathrm{~b}$ is the dominant component in the shelf break samples, and the contribution of this mixture decreases both shoreward and seaward. In this study, four "end member" mineral assemblages could be mixed to account for $90 \%$ of the compositional variability between samples, and additional assemblages added very little information.

When plotted, the proportional contributions to each sample from each of the four end-member assemblages produces the patterns of figure 40. The sediments of outer continental shelf and upper continental slope have similar heavy-mineral compositions (Figure 40a) and are separated along the shelf break by a thin zone with a distinct heavymineral composition (Figure 40b). The patterns of these 
Figure 40. Heavy-mineral composition of samples in terms of proportional heavy-mineral assemblages which approximate the composition of actual samples (end-member samples are represented by stars).

a) Outer continental shelf/upper continental. slope assemblage, containing abundant epidote as the diagnostic mineral.

b) Shelf-break assemblage, containing abundant garnet as the diagnostic mineral. c) Lower continental slope/upper continental rise assemblage, containing abundant hornblende as the diagnostic mineral.

d) Lower continental slope assemblage, containing abundant pyrite as the diagnostic minera1. 

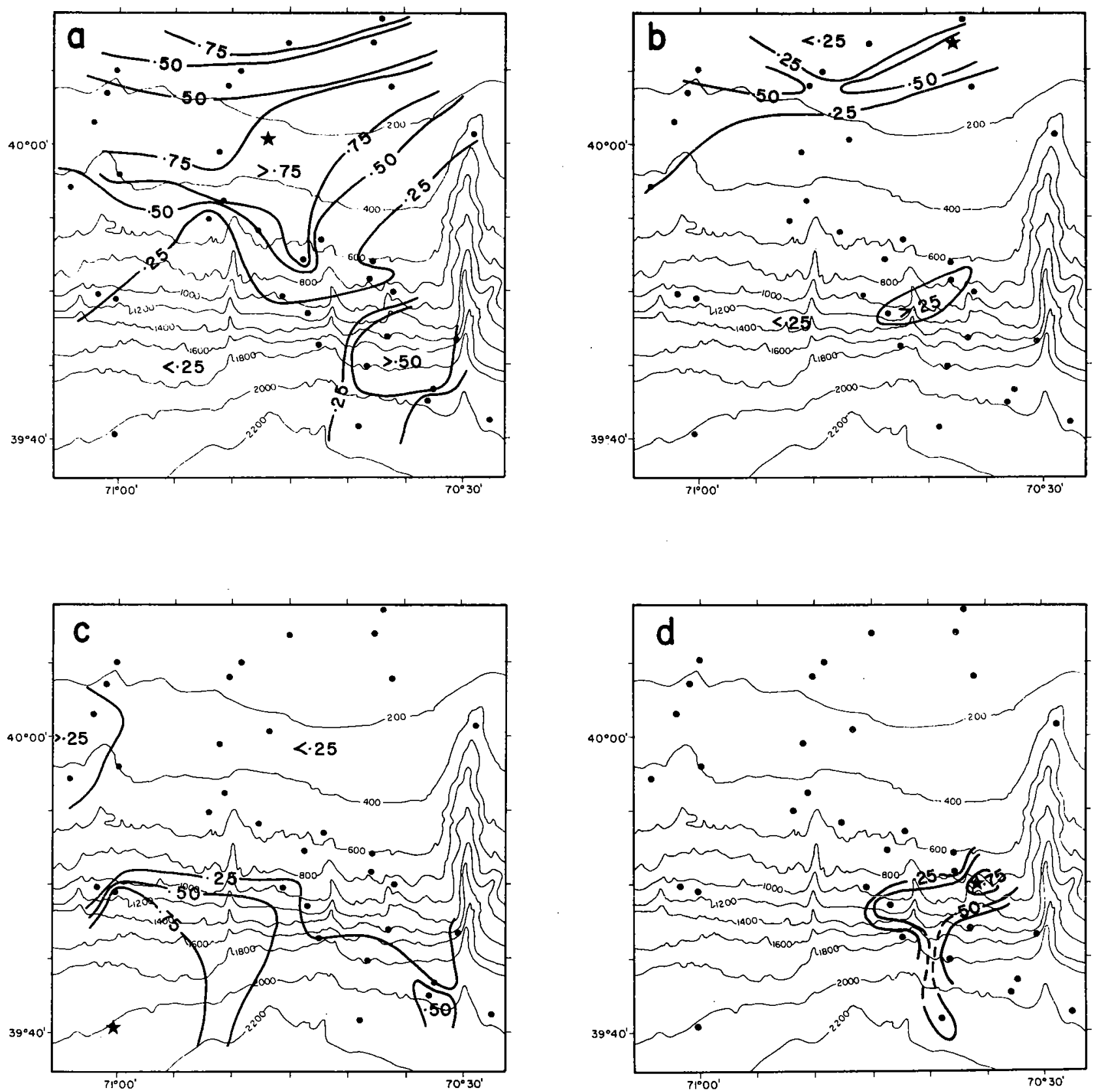

Figure 40. 
two assemblages closely match the changes in texture observed at the shelf break (Fig. 36). A third heavy-mineral assemblage appears to be dominant on the upper continental rise (Fig. 40c), and a fourth assemblage, containing abundant pyrite, occurs locally on the lower continental slope (Fig. 40d). The overall patterns of heavy-mineral compositions are generally parallel to the regional isobaths, with distinct heavy-mineral assemblages occurring at the shelf break, upper continental slope, lower continental slope, and upper continental rise, suggesting separate sources for the detrital sands of each of these physiographic zones. Composition of the silt and clay fractions

The silt fraction of the surface sediments is much more homogeneous in composition than the sand fraction (Fig. 41). Quartz is the most abundant mineral present, composing more than $50 \%$ of the silt fraction on the upper continental slope and shelf break. Calcite in the silt fraction increases downslope, but is always less common than in the sand fraction.

The clay-sized fraction of the samples is dominated by illite (Fig. 42). Illite is most abundant on the upper 
Figure 41. Composition of the silt fraction, based on x-ray diffraction of random powder mounts.
a. Quartz
b. Plagioclase
c. Layered silicates
d. Calcium carbonate 

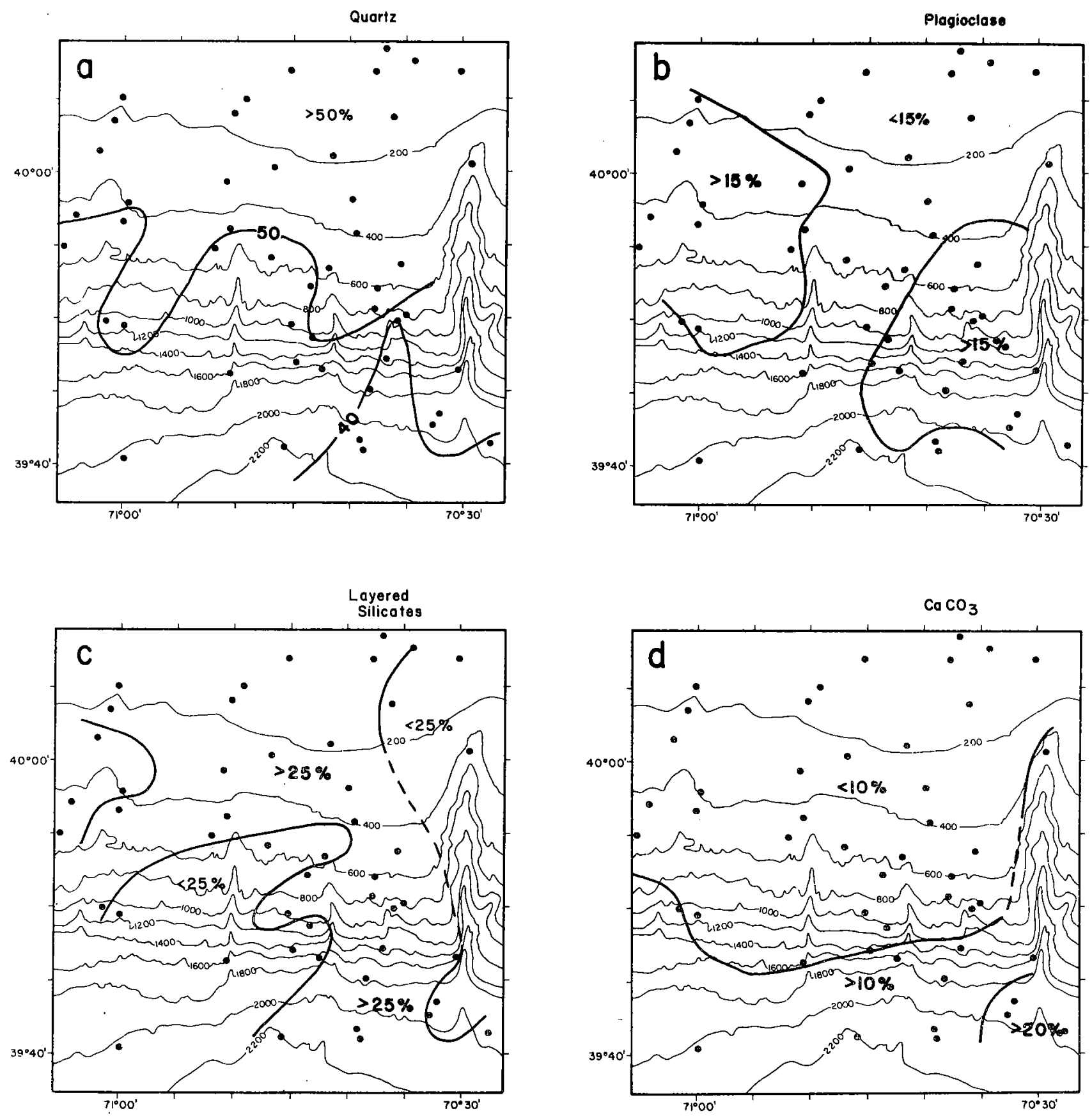

Figure 41. 
Figure 42. Composition of the clay fraction of surface samples, based on x-ray diffraction of oriented aggregates treated with ethelyne glycol.

a. Illite group minerals

b. Kaolinite

c. Chlorite

d. Montmorillonite-group minerals 

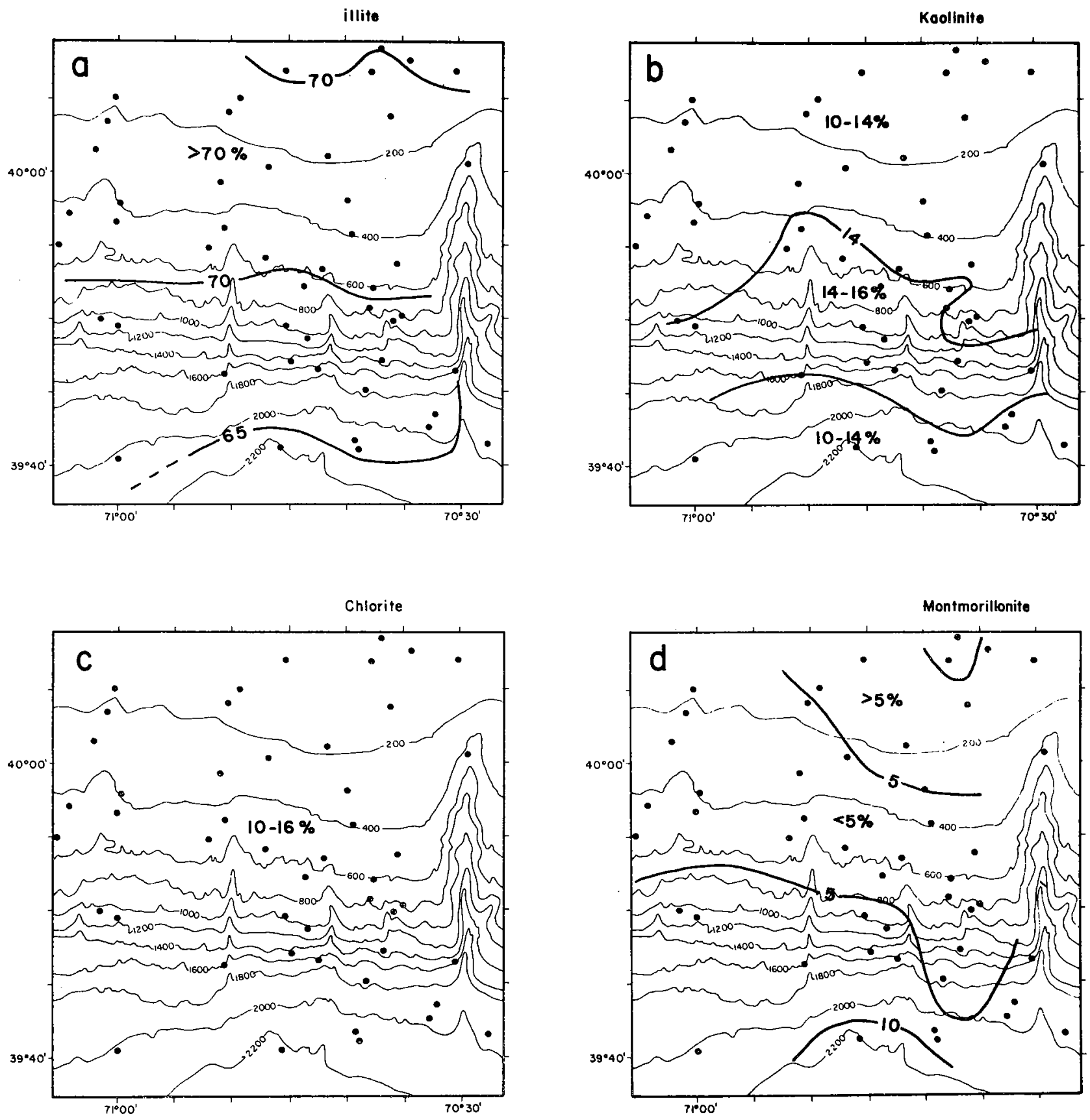

Figure 42. 
continental slope, decreasing slightly shoreward, and more markedly downslope. Chlorite is present throughout the area, and shows no marked trends. Montmorillonite-group minerals are present in small amounts, but tend to be most abundant at the shelf break and on the continental rise. Kaolinite is most abundant on the lower continental slope. Much of this kaolinite may be derived from kaolinite deposits of Upper Cretaceous or earliest Tertiary age similar to those exposed on Marthas Vineyard. The variations of montmorillonite and kaolinite are small and may not be significant, but the patterns of their abundance seem to be consistent with other data.

CORE STUDIES

Introduction

The upper section of sediment was sampled by piston coring, open-barrel coring, and box coring (Fig. 35). Fourteen piston cores were taken within the study area, and a fifteenth was taken about $10 \mathrm{~km}$ south of the area on the upper continental rise. A short open-barrel corer was used as a trip weight for the piston corer, so most of the piston cores are accompanied by an open-barrel core taken simultaneously. In addition, twelve open-barrel 
cores from the area were analyzed, five from the U.S. Geological Survey - Woods Hole Oceanographic Institution sampling program and seven from cruises of the R/V GOSNOLD and ALCOA SEAPROBE (Table 1). Several small box cores were taken at the permanent deep bottom station by DSRV ALVIN.

Cores were typically split in the laboratory, described and photographed, tested for shear strength, sampled, and the samples analyzed in much the same manner as the surface samples (Table 3 ).

The results described below are based primarily on the study of cores taken on ATLANTIS II Cruise 72 . Other cores examined confirm these findings, but because of the age and disturbed nature of some, and the shortness of others, they are not included in the data presentation. In general, the cores consist of sandy and silty lutite; and are green, grey, and brown in color. Sandy layers show no indication of either bedding or graded structure, and finer sediments tend to be horizontally laminated, with layers of the order of a centimeter in thickness. Foraminifera and rates of sediment accumulation 


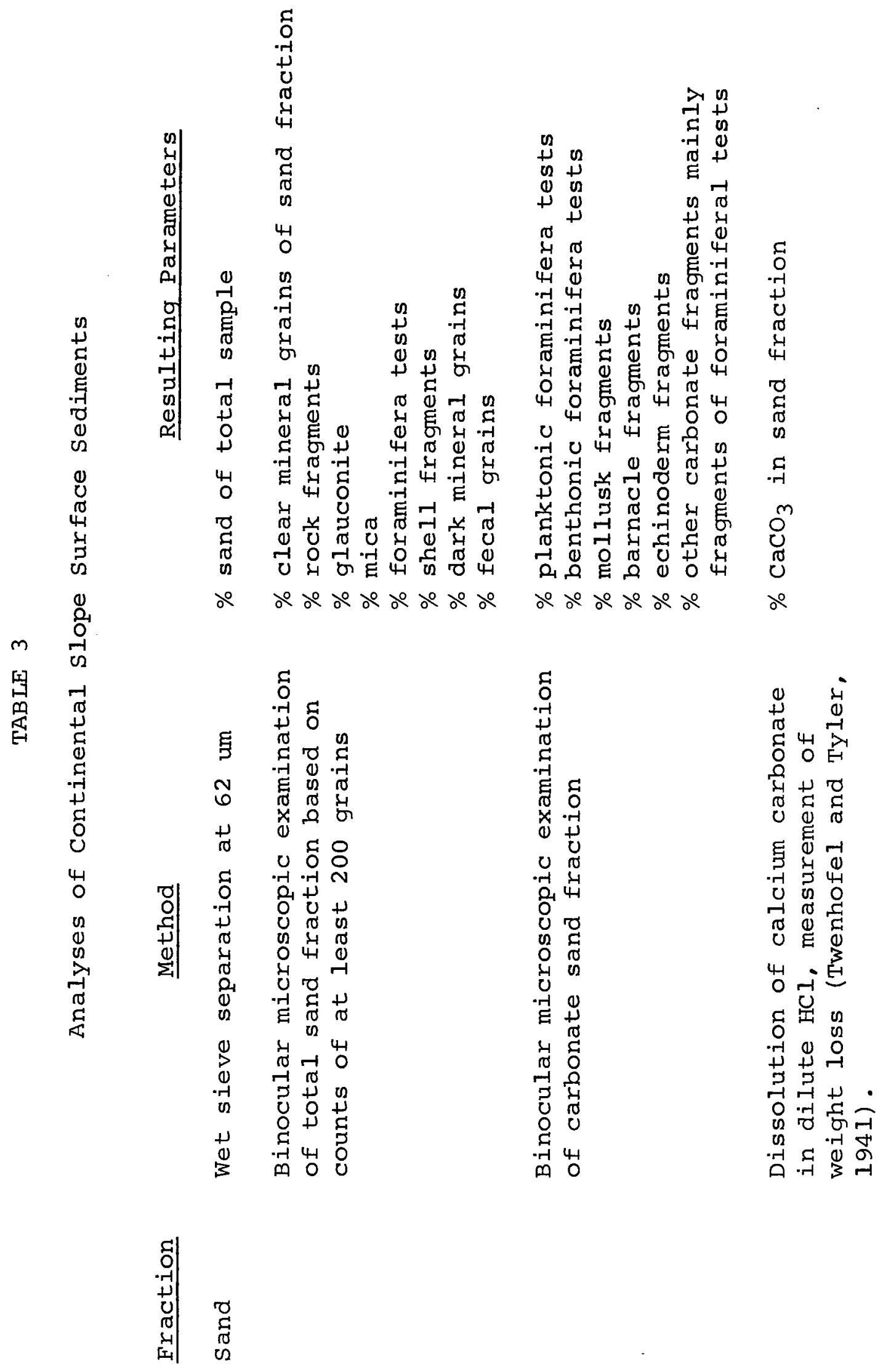




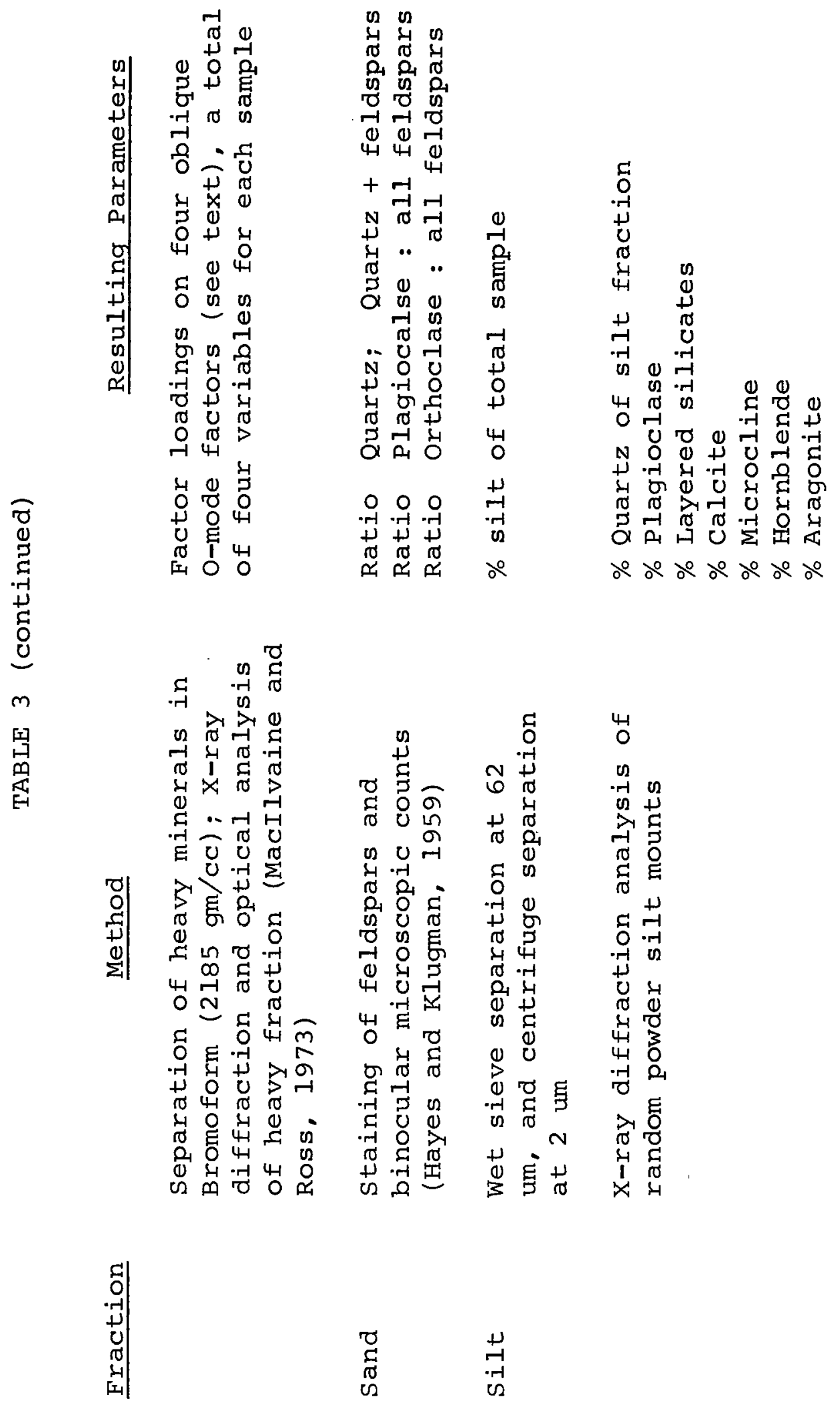




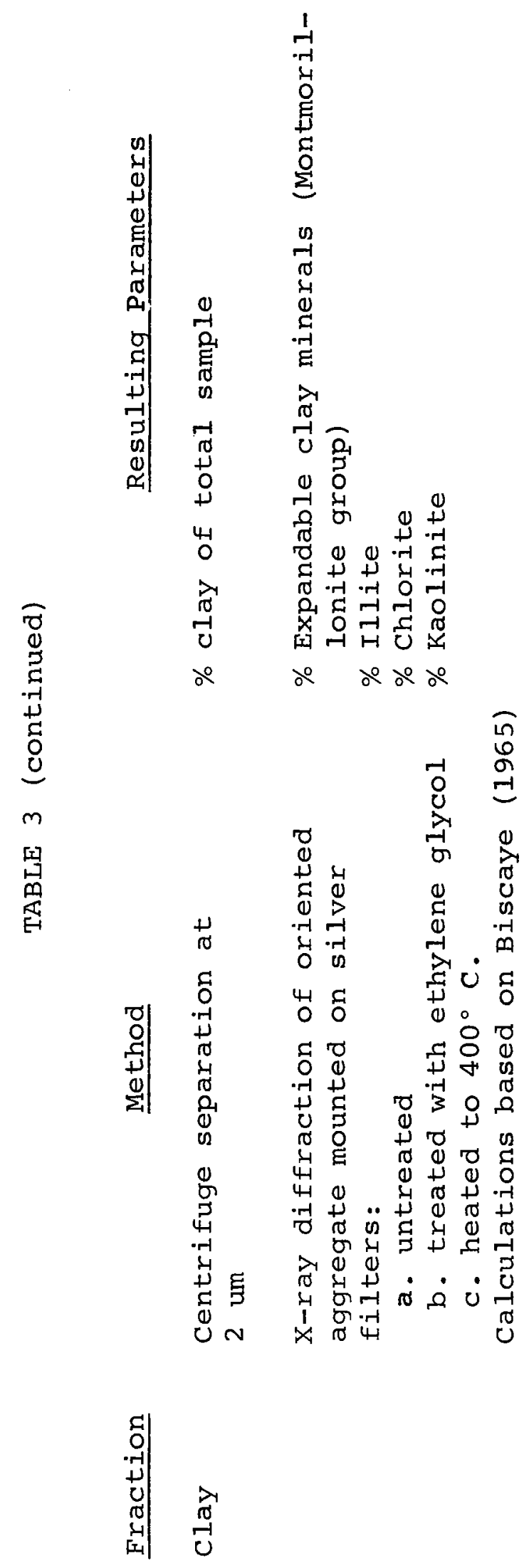


Tests of Foraminifera occur in most core samples, ranging in abundance from trace occurrences to almost the entire sand fraction. In a set of papers based on about 65 short cores from the continental margin between Georges Bank and Chesapeake Bay, Phleger (1939, 1942) determined that a Holocene fauna consisting of temperate to tropical species of Foraminifera can be readily distinguished from an underlying Pleistocene fauna consisting of species which today are confined largely to the arctic.

The change in the cores from cold-water to warm-water assemblages was used in this study to mark the PleistoceneHolocene boundary at the end of the latest glacial advance (Table 4, Fig. 43). More specifically, it marks a transition in the physical environment of the continental slope from subarctic to temperate conditions. This transition is not necessarily synchronous over the entire continental margin; a similar biostratigraphic boundary on the continental slope off the coast of Washington has been shown to be time-transgressive (Barnard and McManus, 1973). It is clear from figure 43 that the piston core failed to sample the upper-most sediment in any core where an openbarrel core was taken simultaneously. The amount of 


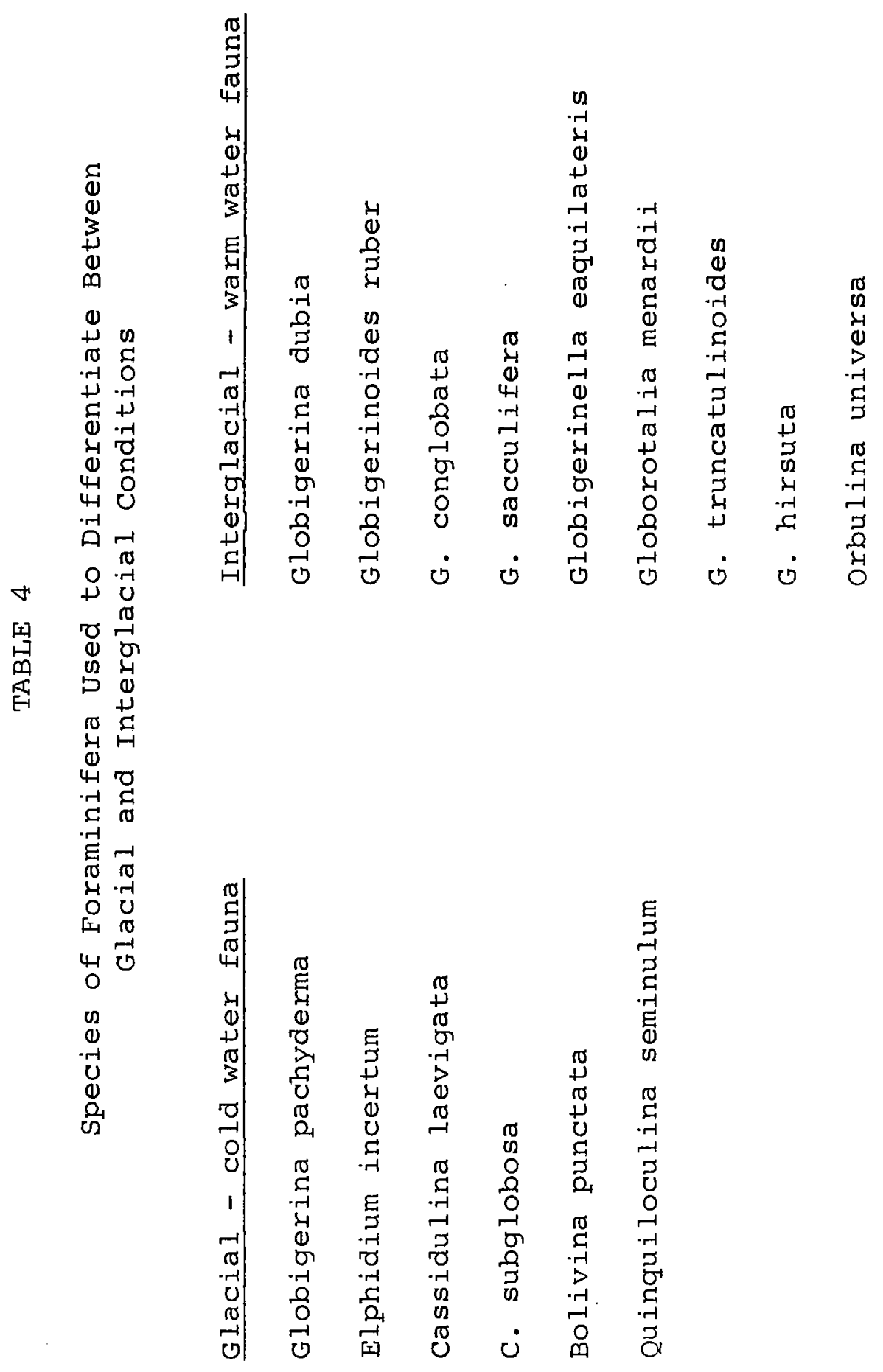


Figure 43. Trends of foraminiferal faunas with depth in cores from the continental slope. Sample positions within cores are shown in Figure 44 . Core positions are projected onto a representative north-south profile. Species used are listed in Table 4.

C: cold-water assemblages

W: warm-water assemblages 


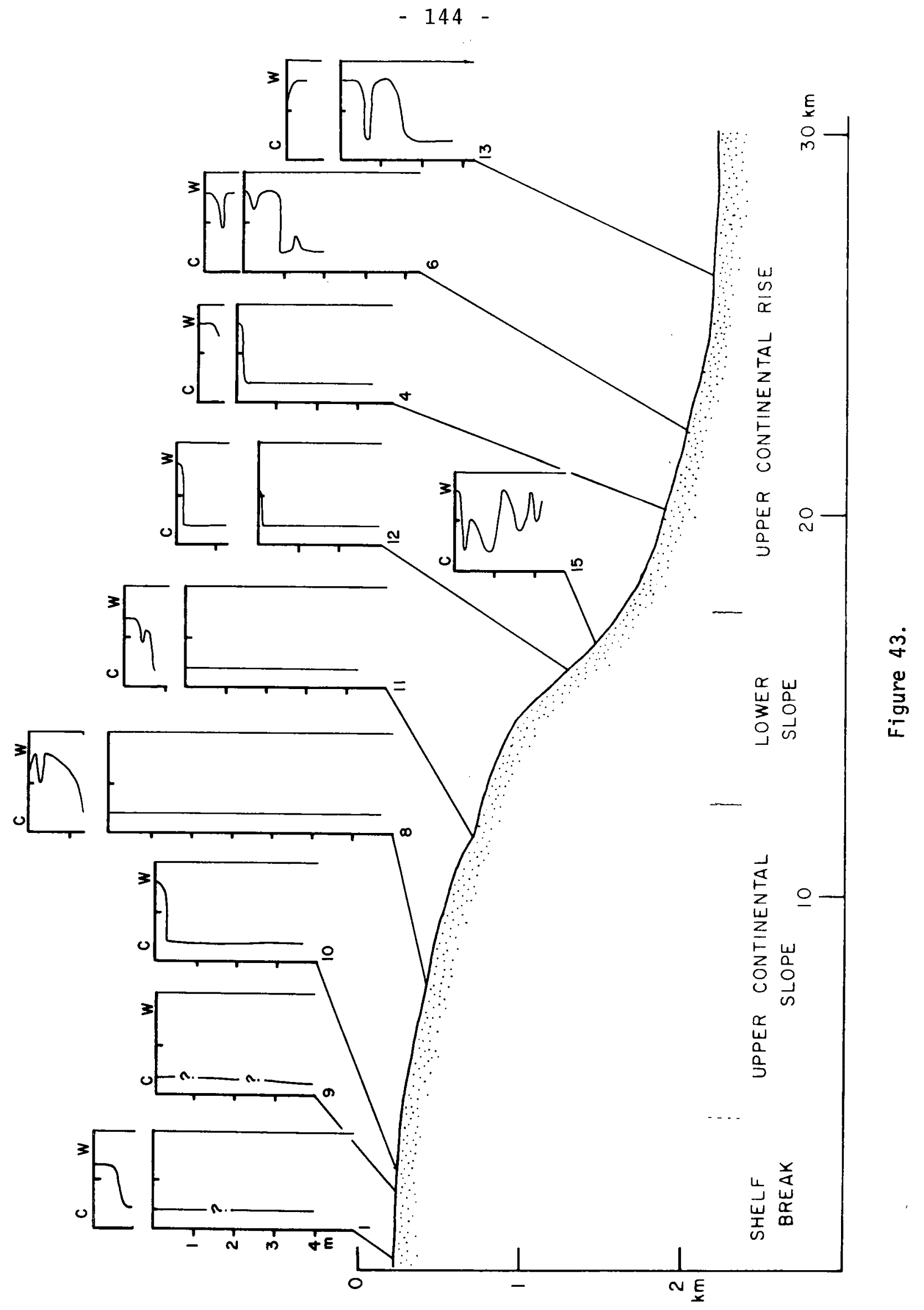


missing material varies from a few centimeters in cores 6 and 12 to an undetermined length of more than a meter in cores 1,8 , and 11 .

The Foraminiferal fauna varied systematically with water depth, as first noted by Phleger (1942). In the shelf-break cores 1 and 9 , the fauna is extremely impoverished and is composed of benthonic forms. In deeper water, warm-water planktonic Foraminifera form an increased percentage of the sand fraction of the Holocene section. Pleistocene samples contain a more uniform fauna over the area, consisting of relatively few species (Table 4), but with increased proportions of the planktonic Globigerina pachyderma relative to benthonic forms with increasing depth.

The shapes of several of the temperature curves of figure 42 closely match the generalized paleotemperature curve of Emiliani (1971). The beginning of the major warming trend would take place at 15,000 to 18,000 years B.P. (the Pleistocene-Holocene boundary in deep-sea sediments is generally placed at 11,000 years B.P., within this warming trend). A temperature maximum occurred at about 9,000 years B.P., a minor temperature minimum at 
6,000 years B.P., and a final maximum at 3,000 years B.P. followed by a slight cooling to the present. These features are evident in cores 8 and 11 from the upper continental slope, and in cores 6 and 13 from the lower continental slope. Other cores contain only the major warming trend of the Pleistocene-Holocene boundary.

Rates of sediment accumulation were calculated based on Emiliani's time scale. Holocene sediment accumulation is greatest on the upper continental slope and upper continental rise $\left(\geqslant 15 \mathrm{~cm} / 10^{3}\right.$ years in cores $8,11,6$, and 13), and very low on the steep lower continental slope $\left(\leqslant 2 \mathrm{~cm} / 10^{3}\right.$ years in cores 12 and 15$)$. Rates of Pleistocene sediment accumulation are more difficult to ascertain, since only core 15 reaches a pre-Wisconsin warm period. Core 8 on the upper continental slope shows the largest section of Wisconsin-age sediments $\left(25 \mathrm{~cm} / 10^{3}\right.$ years, assuming an age at the base of the core of 30,000 years). Core 15, on the lower continental slope, appears to have a very low net accumulation of pleistocene sediments. Assuming that the sequence is continuous and the temperature fluctuations within the core correspond to Emiliani's paleotemperature curve, which would place the 
base of core 15 at 90,000 years B.P., the net accumulation rate is on. the order of $2 \mathrm{~cm} / 10^{3}$ years. Texture and Shear strength

The vertical distribution of sediment texture within the cores varies dramatically within the study area (Fig. 44). Near the shelf break, cores sampled sands (cores 1, 9), which became slightly finer grained at the surface. The Pleistocene sections of these cores show little variation of texture with depth within the cores, but a slight tendency toward finer sediments offshore (core 9). Core 10, also near the shelf break, contains an upper sandy layer similar to cores 1 and 9, and a lower, finer grained section, with the two layers separated by a sharp boundary. The Pleistocene to Holocene warming indicated by the planktonic Foraminifera assemblages occurs within the lower portion of the upper sandy layer.

The upper continental slope cores (8 and 11) show a marked increase in sand content in the Holocene, and, in addition, core 11 has layers of increased sand content at depth. Lower continental slope cores (12 and 15) have a much smaller increase in grain size in the Holocene. Upper continental rise cores $(4,6$, and 13) show sharp grain-size 
Figure 44. Textural composition of cores from the study area, showing proportions of sand (stippled), silt (clear), and clay (lines). Sample positions are shown by dots on the right of each core. Core positions are projected onto a representative north-south depth profile. 


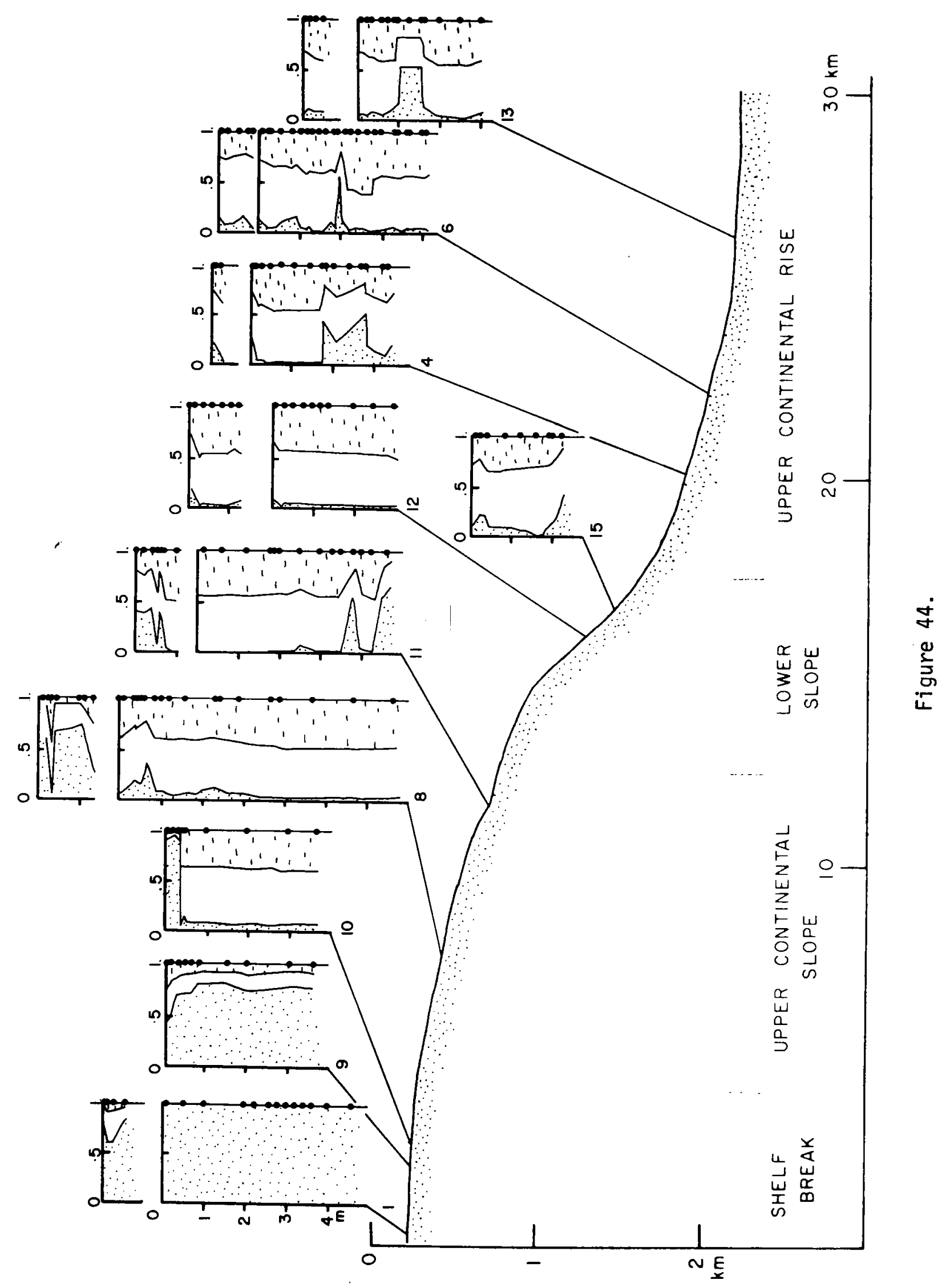


variations within the Pleistocene section.

The increase in sand content of the uppermost sediment on the lower continental slope was examined in more detail by continuous sampling at $1 \mathrm{~cm}$ intervals of an undisturbed box core $8 \mathrm{~cm}$ long taken by DSRV ALVIN at the permanent deep bottom station on the lower continental slope (Fig. 35). Reverse grading is clearly present within the top few centimeters of the sediment sampled at this station, the sand content increasing from $35 \%$ at the base $(8 \mathrm{~cm})$ to over $50 \%$ at the surface.

Shear-strength measurements were made by a single operator using a Torvane* hand-held vane-type shear meter at positions in the cores at which samples were taken (Fig. 45). In several cores, abrupt changes in shear strength coincide with changes in sediment character. In core 10, near the shelf break, the shear-strength boundary coincides with the abrupt change in texture from sands above to clayey silt below. The sediment below the boundary is clearly overconsolidated as compared to other cores of similar sediment type (core 8, for example), indicating that a considerable thickness of Pleistocene material was removed before deposition of the top sand layer. The 
$-151-$

Figure 45. Shear strength of cores from the study area, in tons per square foot. Sample positions are shown in Figure 44. In core 8, additional measurements were taken at $15 \mathrm{~cm}$ intervals throughout the core. 


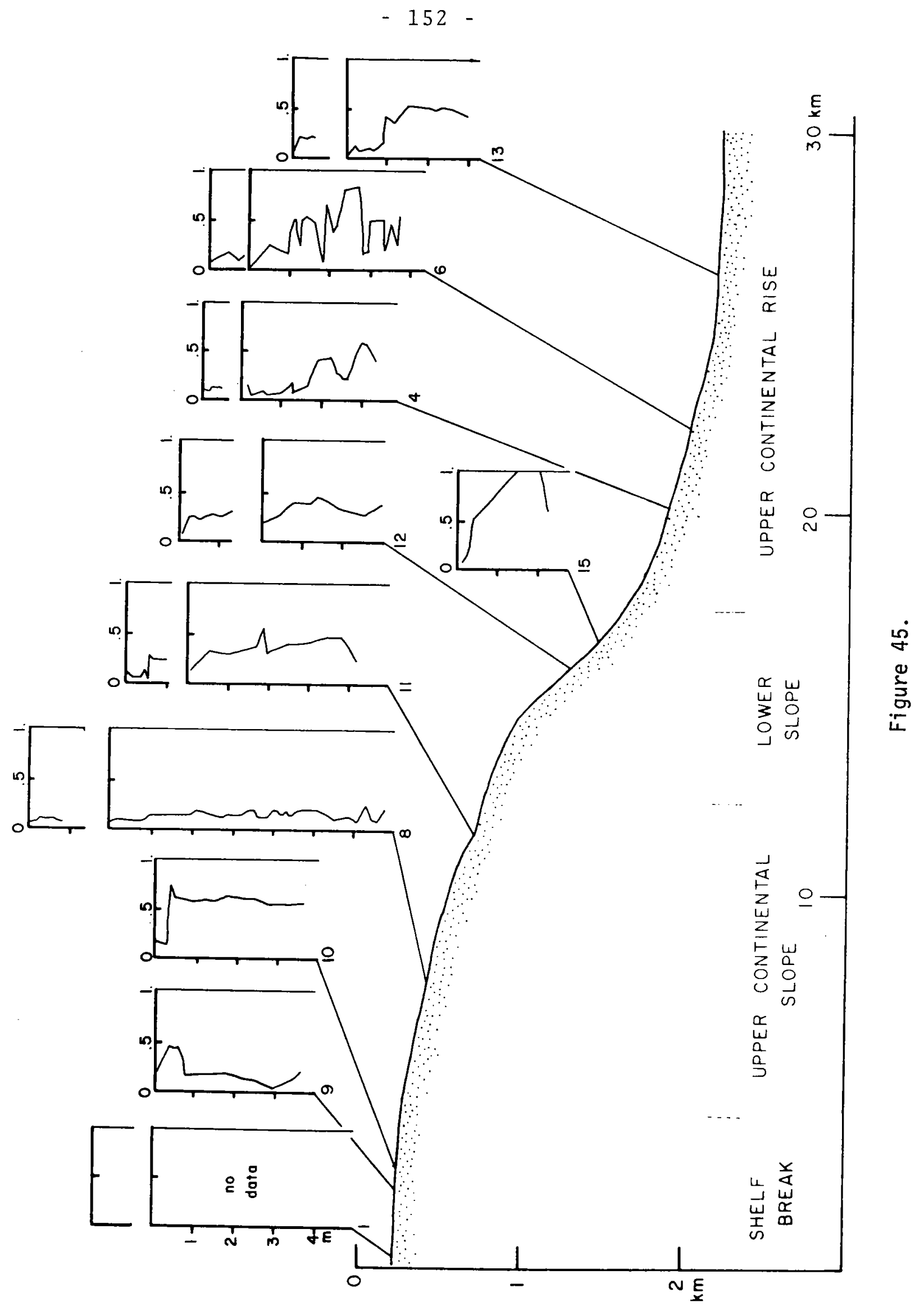


Pleistocene-Holocene boundary in core 10 lies within the sandy layer above the discontinuity in texture and strength, and is similar to the foraminiferal change seen in cores 1 and 9, indicating that erosion and the beginning of sand deposition took place during the Pleistocene. Cores from the steeper portions of the continental slope (cores 11, 12, and 15) have higher shear-strength values than adjacent cores from more gentle slopes (cores 4 and 8 ). Core 15 shows a rapid increase in shear strength with depth, reaching values greater than 1 ton/square foot at two meters depth. Core 15 also contains warm water Foraminifera alternating with colder faunas to its base, suggesting that this core contains older Pleistocene material.

Cores from the upper continental rise contain abrupt shear-strength boundaries, many of which correspond to textural boundaries. Most of these shear-strength boundaries are clearly angular unconformities, with the appearance of sharply defined faults cutting bedding planes at moderate to high angles $\left(20-50^{\circ}\right)$. In most cases, the bedding planes are nearly horizontal and apparently undisturbed, but in some sections the bedding is convolute, 
and in others, especially those layers with very low shear strength, the bedding has apparently been destroyed altogether.

Mineralogy of Cores

Variations of mineralogy within the cores often occur at discontinuities in shear strength and texture. The sand and silt fractions show similar trends, and they will be discussed separately from the clay fraction.

The sands and silts of the shelf-break area (cores 1 , 9) are dominated by quartz and feldspars, and have little variation in composition with depth in the cores (Figs. 46, 47). Core 10 has a composition similar to cores 1 and 9 in its upper sandy portion, but the older finegrained material contains abundant mica. Core 8, from the upper continental slope, shows gradual compositional variation with depth. Like core 10, it contains mica, and, in addition, contains abundant sand-sized fragments of detrital sedimentary rock, the proportion of rock fragments increasing toward the base of the core. The gravity core section of core 11 from the upper continental slope is similar in composition to cores 8 and 10 , but the piston core contains four units characterized by abundant sand- 
Figure 46. Proportional composition of sand fraction in cores from the study area. Sample positions within cores are shown in Figure 44. Core positions are projected onto a representative north-south depth profile.

q: quartz and feldspars

f: foraminifera tests

$\mathrm{m}$ : mica flakes

$r$ : rock fragments

g: glauconite grains

d: dark minerals

The unlabeled column at far right in each core is "others." 


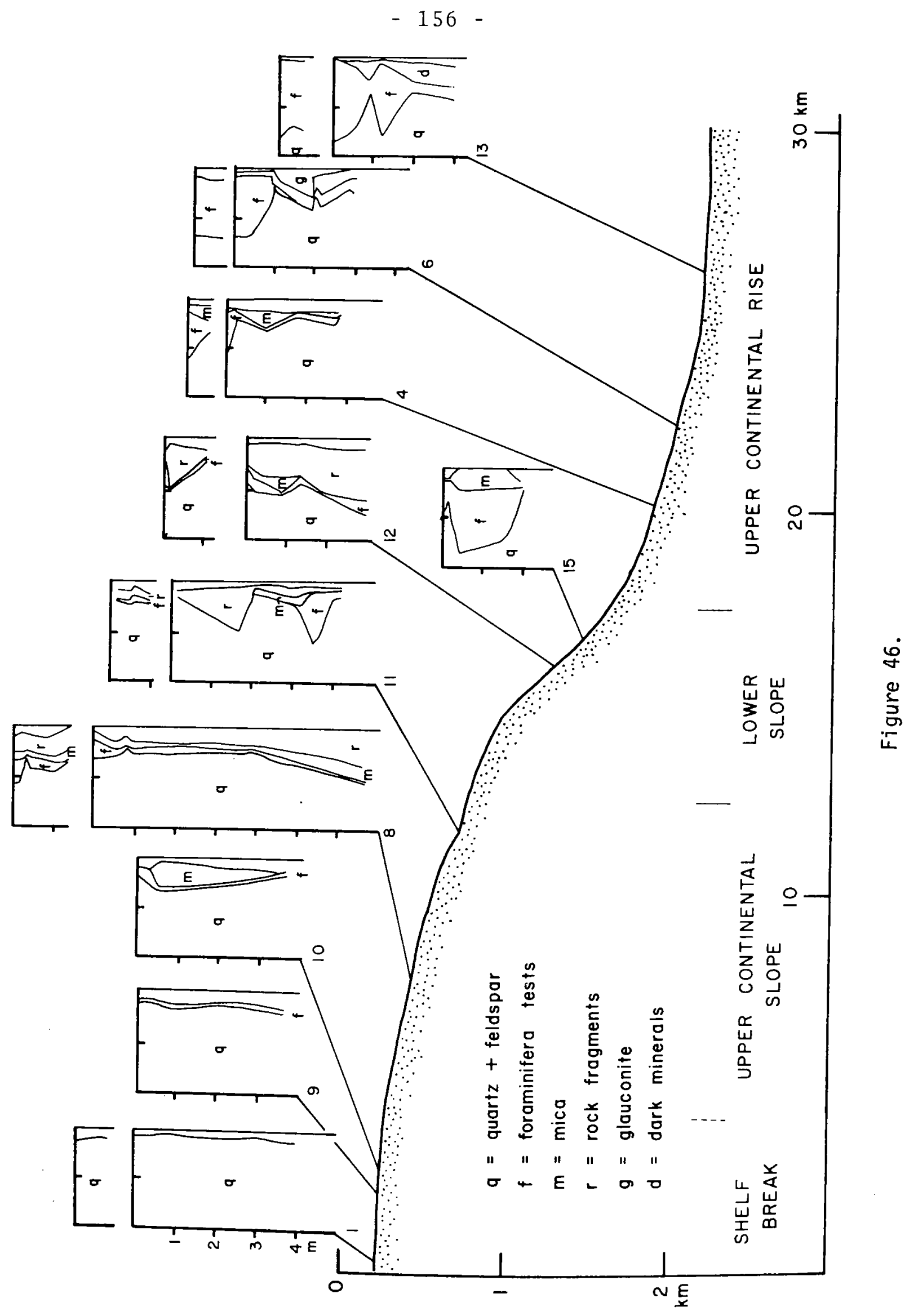


Figure 47. Silt composition of cores from the study area. Sample positions within cores are shown in Figure 44. Core positions are projected onto a representative north-south depth profile. q: quartz

p: plagioclase

1: layered silicates

c: calcite Unlabeled column is "others." 


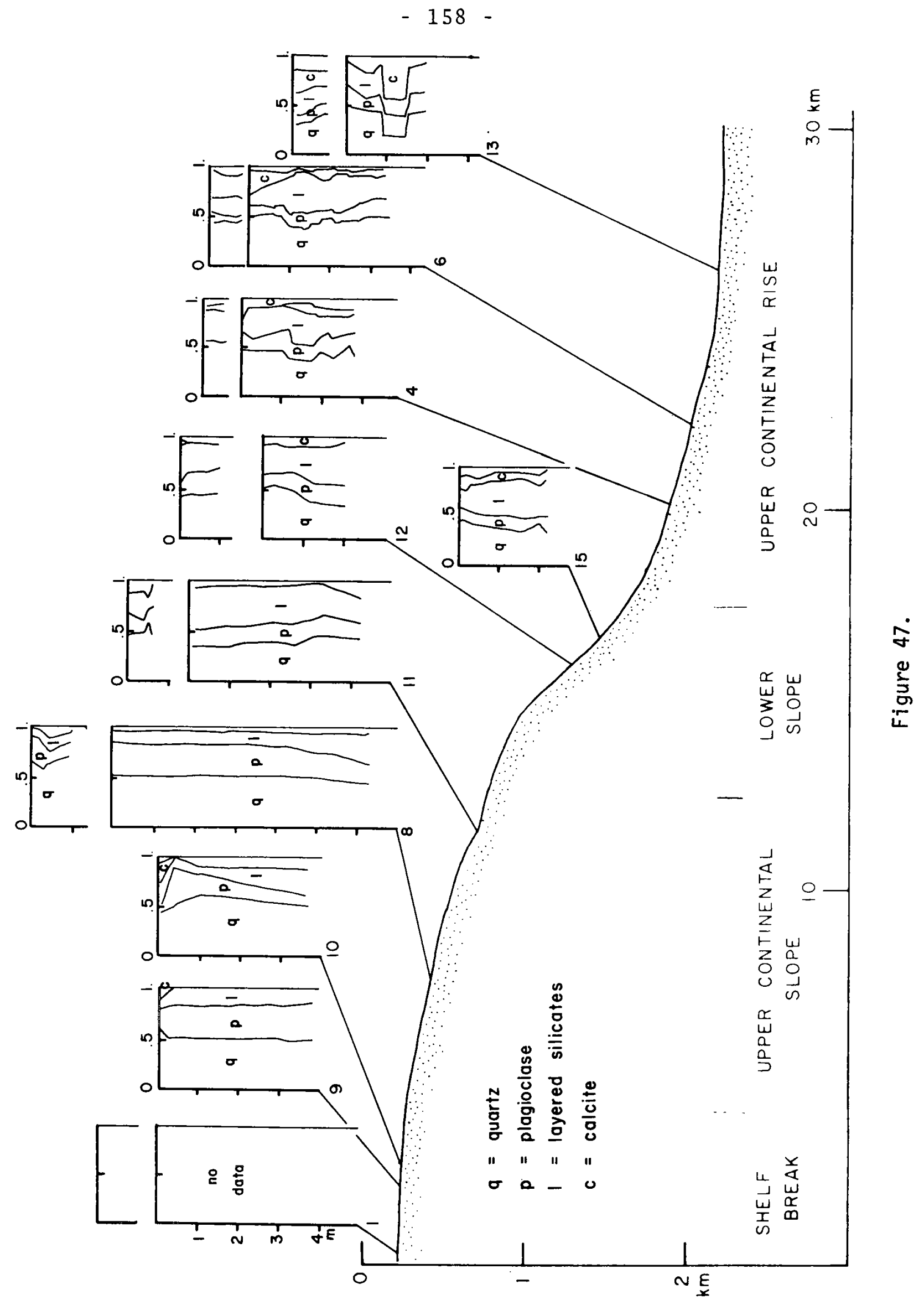


sized rock fragments, mica, cold-water planktonic Foraminifera, and quartz alone, each separated by boundaries which are reflected in the shear strength and textural data.

Core 12 from the lower continental slope contains abundant fragments of sedimentary rocks in the sand fraction and layered silicates in the silt fraction. Core 15 is dominated by Foraminifera and mica, but has quartzose sand layers at top and bottom. Like core 12, it contains abundant layered silicates in the silt fraction.

Cores from the upper continental rise (Cores 4, 6, 13) show marked changes in sand and silt composition at unconformities. Some units are similar in composition to continental-slope material, but other sections have compositions unlike those observed upslope. Core 6 , for example, has abundant glauconite in one layer, and core 13 contains abundant silt-sized calcite in the sandy layer at 1 to 1.6 meters and a high proportion of dark minerals in the sand fraction below this zone. The clay fraction is much more homogenous with depth within the cores than the silt and sand fractions (Fig. 48). In almost all cores a general trend toward increased amounts 
Figure 48. Ratio reflecting relative amounts of montmorillonite and illite groups of clay minerals in cores from the study area. Values based on the ratio of the increase of the $10 \mathrm{~A}$ peak upon heating the glycolated sample to $400^{\circ} \mathrm{C}$ to the area of the glycolated $10 \mathrm{~A}$ peak; high values reflect greater content of montmorillonite relative to illite. Core positions are projected onto a representative northsouth profile. 


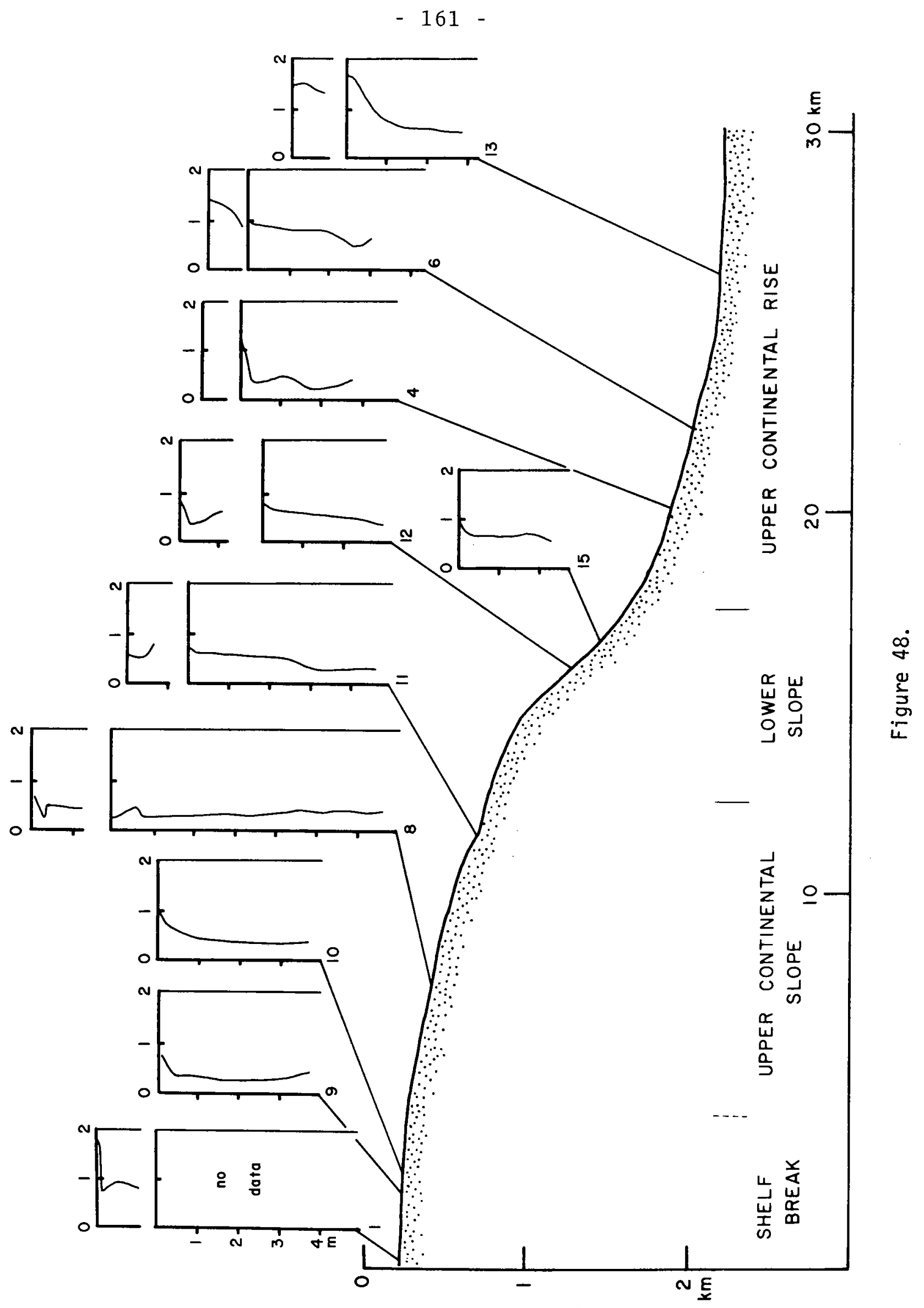


of expanding-layer montmorillonite-group minerals and decreased illite content towards the surface can be discerned. In some cores (for example, cores 11, 12, and 6) this trend is gradual over several meters of core length, while in others (cores 1,4) it is more abrupt and close to the surface. 


\section{CHAPTER III}

\section{SUMMARY OF DATA}

The most important results of the previous sections are summarized in figures 49, 50, and 51. The data from all techniques are combined in a description of each province within the study area. The provinces within the study area include the outer continental shelf, which extends from the northern edge of the area to about 125 $150 \mathrm{~m}$; a shelf break, transitional between shelf and continental slope; a gently sloping $\left(1.4^{\circ}\right)$ upper continental slope between the shelf break and about $800 \mathrm{~m}$; a steeply sloping $\left(7.6^{\circ}\right)$ lower continental slope which extends to about $1800 \mathrm{~m}$; and an upper continental rise, which decreases in gradient from the base of the lower continental slope, reaching a gradient of $1.5^{\circ}$ at $2000 \mathrm{~m}$. The outer continental shelf is smooth-surfaced. Deep internal reflectors are generally concordant, and dip gently seaward. The bottom is covered with finegrained sediment which apparently overlies a transgressive sand layer. Near-bottom waters contain high concentrations of suspended sediment. 
Figure 49. Summary of physiography and shallow structure, derived from 1) echosounding, 2) 3.5 $\mathrm{kHz}$ profliling, and 3 ) seismic reflection profiling. 


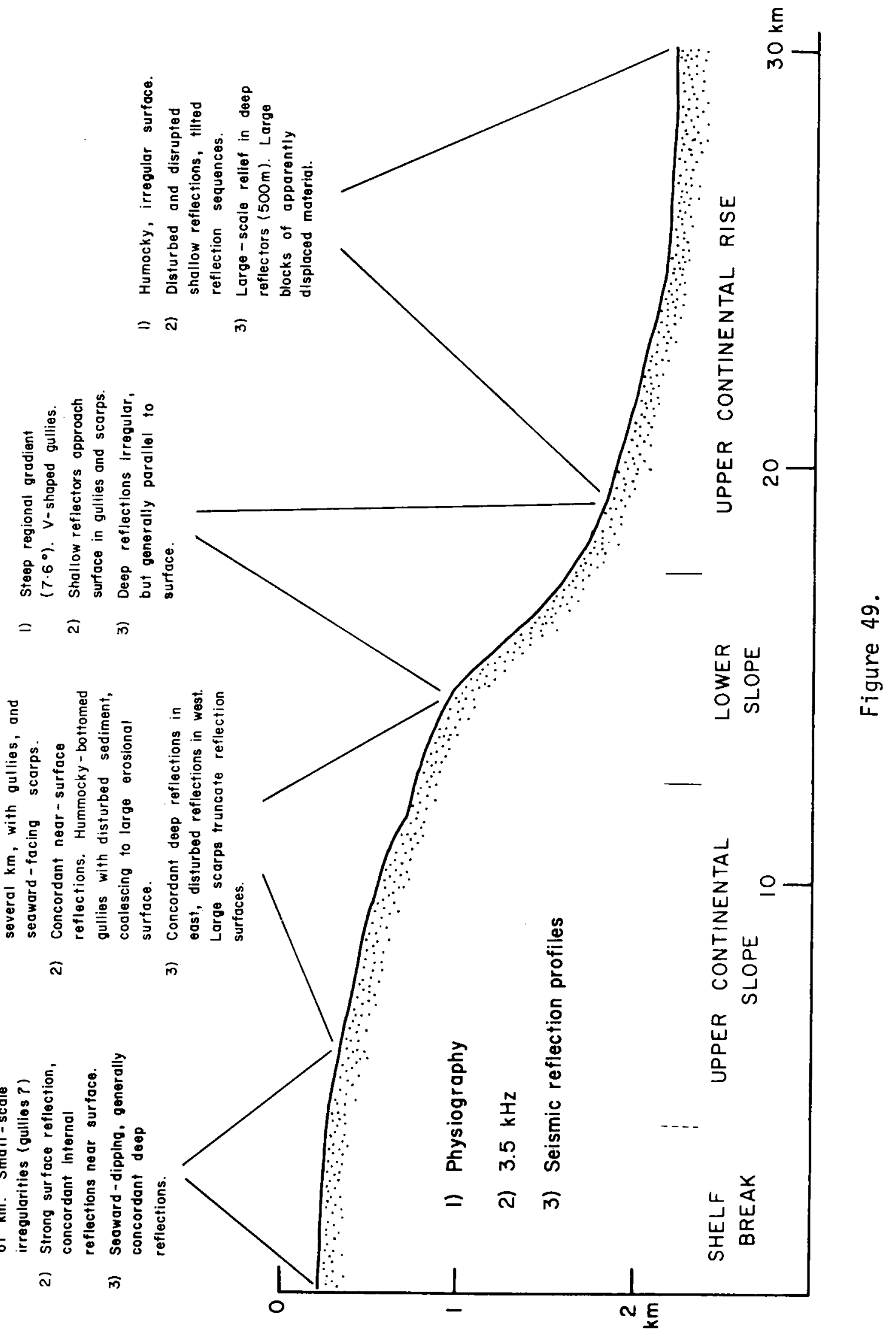


$-166-$

Figure 50. Summary of 1) suspended sediments, 2) character of the sediment surface, and 3) epibenthic fauna. 
- 167 -
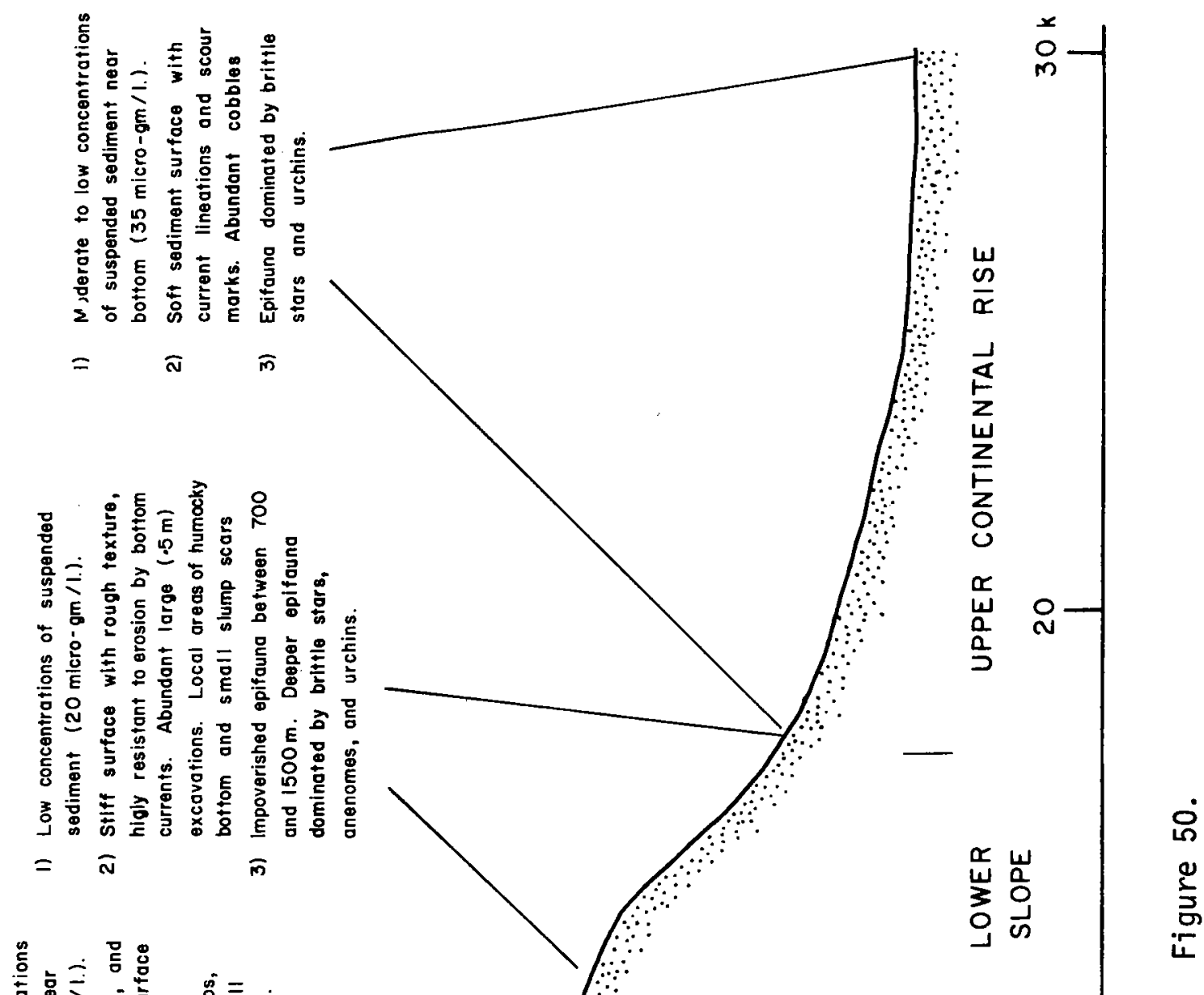

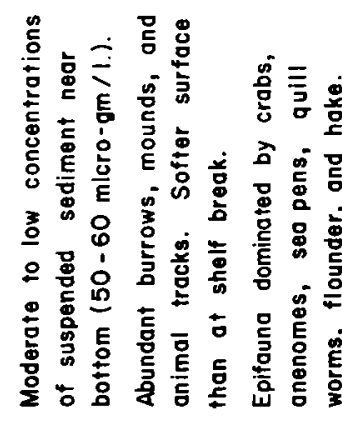

$=$ ल

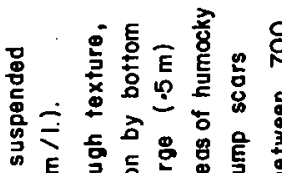

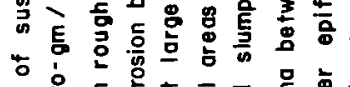

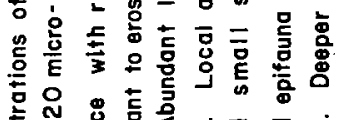

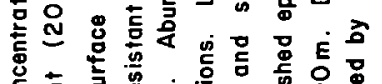

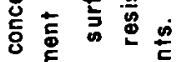

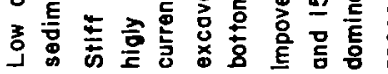

$=\widehat{\mathrm{N}}$ 
Figure 51. Summary of the characteristics of Holocene and Pleistocene sediments. 


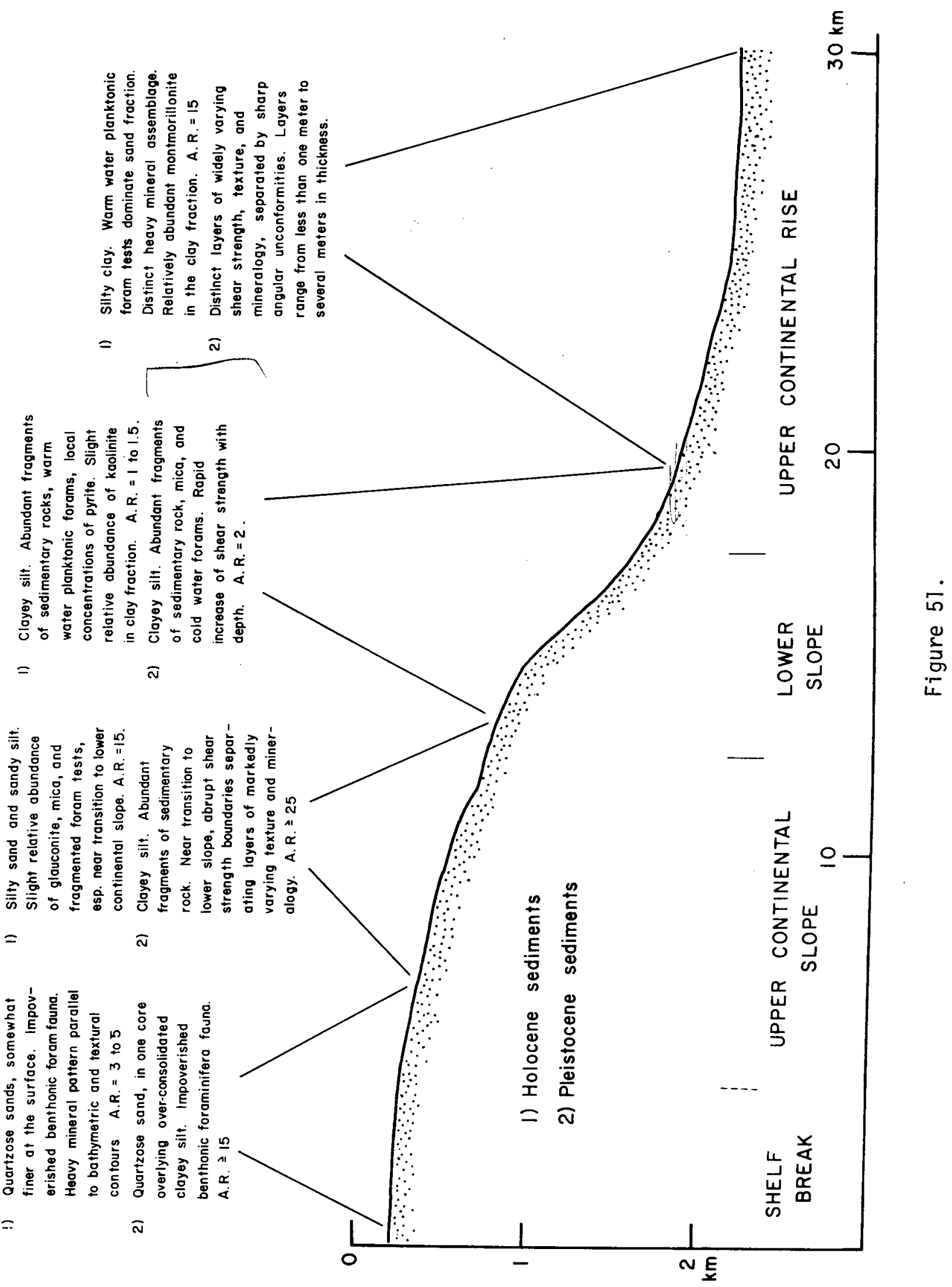


A thin zone of coarse-grained surface sediment occurs at the shelf-break. The surface sediments in this zone are distinct from the sediments on both the outer continental shelf and the upper continental slope in terms of grain size, heavy accessary minerals, and Foraminifera fauna. The sandy surface sediments apparently produce strong surface reflections on $3.5 \mathrm{kHz}$ records, and mask internal reflections. The surface near the shelf-break and on the uppermost continental slope has small-scale relief, perhaps in the form of small V-shaped gullies. The shallow internal reflections are concordant and parallel to the sediment surface where they are observed. The upper continental slope is generally smooth, but is dissected by steep-sided gullies and seaward-facing scarps. The gullies are tens of meters deep, have hummocky floors, and contain residual, disturbed material. Near the transition to the steeper lower continental slope the gullies apparently coalesce into large erosional surfaces. Steep seaward-facing scarps occur near the transition between upper continental slope and lower continental slope. They are hundreds of meters in relief, and indicate large-scale failure and downslope displacement of sediment. 
The sediments of the upper continental slope grade upward from rapidly deposited Pleistocene clayey silts with abundant fragments of sedimentary rocks to Holocene silty sands and sandy silts. The distinguishing features of sediments of the upper continental slope are slight relative abundances of glauconite, fragmented Foraminifera tests, and mica.

The lower continental slope has a relatively steep regional gradient $\left(7.6^{\circ}\right)$ and is dissected by steep-sided V-shaped gullies, without the layer of disturbed material which is observed on the upper continental slope. Internal seismic reflections are discontinuous, and tend to approach the surface at scarps and gullies. Small-scale slump scars on the order of $100 \mathrm{~m}$ horizontal dimension and several m relief expose bedded sedimentary rocks of probable Pleistocene and perhpas Upper Cretaceous age. The sediments of the lower continental slope show a rapid increase in shear strength with depth and a much lower net accumulation rate than on the upper continental slope. The sediment surface is more rough than further upslope and is stiff, cohesive, and resistant to erosion by bottom currents. 
The upper continental rise has a hummocky, irregular surface in $3.5 \mathrm{kHz}$ and seismic profiles, with disturbed and tilted reflection sequences and large blocks of apparently displaced material. The cores show abrupt boundaries marked by angular unconformities between layers of markedly varying properties. The sediment surface is smooth, soft, and marked by current lineations and scour. Patches of cobbles are abundant. Glacial erratics are two to four orders of magnitude more abundant on the upper continental rise than on the lower continental slope. 
CHAPTER IV

DISCUSSION OF RESULTS

\section{INTRODUCTION}

The data presented in the previous sections, if combined with previously published results by a number of workers, form the framework for a discussion of the sedimentary environment of the continental slope in terms of the sedimentary processes which control the deposition and erosion of sediment and the geomorphology of the continental slope.

The sedimentary processes which appear to be active on the continental slope include gravitational (turbidity currents, creep, and slumping), hydrodynamic, and biological processes. The data bear mainly on the Pleistocene and Holocene conditions, and they will receive primary consideration in this discussion. Although representing only a small portion of the time that the continental slope has been in existence, the Pleistocene and Holocene have encompassed a wide range of sedimentary conditions. The possible pre-Pleistocene conditions will be speculated upon later. It is probable that the processes active during the Pleistocene and Holocene were also active in earlier periods, perhaps to greater or lesser extent, or 
in different combinations. GRAVITATIONAL PROCESSES

The data gathered during this investigation indicate that gravitational processes (slumping, turbidity currents, and creep) have caused erosion of Pleistocene deposits on the continental slope. The presence of slump scars has been confirmed by seismic profiles, bottom photographs, and direct observation from submersible. Slump scars vary in areal extent from several kilometers to tens of meters, and in relief from hundreds of meters to about one meter. Large-scale slumping (hundreds of meters thick) seems to be most active at the transition from upper continental slope to lower continental slope. The gradient of the upper continental slope is gentle enough to allow rapid accumulation of sediment, causing oversteepening of the deposits on the brink of the steep lower continental slope, which becomes unstable and moves downslope as large blocks of sediment. In this area of large-scale slumping, Eocene rocks are exposed at the surface (Stetson, 1949; Northrup and Heezen, 1951; Gibson, Hazel, and Mello, 1968) and components of Tertiary rocks (glauconite, Foraminifera, and perhaps mica) have been reworked into the Pleistocene 
deposits. Apparently, the entire Pleistocene section, as well as an undetermined amount of Tertiary material, has been subject to slumping in this area near the transition between upper and lower continental slope. Medium-scale slumping (tens of meters thick) occurs most often on the upper continental slope, where rapid deposition has caused unstable conditions within the top few tens of meters. When failure occurs on the upper continental slope (possibly from upslope propagation of slumping near the transition to lower continental slope), material is only partially removed, leaving a deposit of disturbed material in gully-like depressions.

Small-scale slumping (one to several meters thick) occurs on the steep lower continental slope. Slumps on the order of tens of meters in extent and a few meters relief are common, and can be attributed to the steep incline of the bottom, allowing only a few meters of rapid deposition under stable conditions. Although slumps of small extent involve much less material than those from farther upslope, they must have taken place much more often during periods of rapid deposition, as evidenced by the extremely low net accumulation rates and abundance of small 
scars on the lower continental slope which expose consolidated material.

Although no Cretaceous material has been recovered from the lower continental slope, Cretaceous samples have been taken from Alvin Canyon (Gibson, Hazel, and Mello, 1968). The presence of kaolinite (which is abundant in Upper Cretaceous Coastal Plain deposits), the approach of deep acoustic reflectors to the surface, and the abundance of sedimentary rock fragments on the lower continental slope suggest that upper Cretaceous rocks are present beneath thin Pleistocene deposits, and may crop out locally where the pleistocene material has been removed.

There is no accurate way to judge the amount of material removed from the continental slope during the Pleistocene by slumping, but the amount must be significant. Taking a reasonable accumulation rate of $35 \mathrm{~cm} / 10^{3}$ years (as in core pc-8) for half the time of the Pleistocene gives a total potential accumulation on the lower continental slope of 350 meters, or about 5 billion cubic meters of sediment per kilometer of margin lengh. Almost all of this sediment has been removed from the lower continental slope. 
Previous studies of the stability of marine sediment have been based on the "infinite slope" method (Taylor, 1948). The increase in shear strength with depth in the sediments as measured in short cores is assumed to continue downward into the section. The downslope shearing stress generated by overburden also increases with depth. If the increase in shear strength with depth is greater than the increase in shearing stress, the sediment is said to be stable.

Moore (1961) found that by the infinite slope method the sediments from basin slopes and the continental slope off southern California show "a remarkable degree of stability", and concluded that the slumping which apparently gives rise to turbidity current deposits must be confined to "collecting areas" such as gullies, canyons, and other elongate depressions which act as sediment traps.

Morelock (1969) found that although the topography of the area he studied on the continental slope of the western Gulf of Mexico suggested local slumping, the infinite slope analysis and values of shear strength measured by a number of techniques indicated stable deposits. Ross (1971) found that slumping is possible on the landward flank of 
the northern part of the Middle America Trench at slope angles of $10^{\circ}-15^{\circ}$.

The infinite slope method correctly applies only to slopes of large lateral extent as compared to the thickness of slumped section. The upper continental slope and lower continental slope (but not the transitional zone between them) have been shown in this study to be subject to slumps of small thickness compared to the lateral extent of the slope. Stability analysis by the infinite slope method may be valid for these slopes. Such analysis on the piston cores from the study area indicates that the pleistocene and Holocene sections are theoretically stable in all cores for the slopes on which they occur.

This finding casts some doubt on the reliability of the simple infinite slope method based on vane shear measurements of piston cores for predicting instability in the marine environment. one might, in fact, intuitively expect such an analysis to overestimate the stability of submarine slopes. Even in an area of abundant shallow slumping, the sediments sampled by piston coring are just those deposits which are strong enough to remain on a given slope; the weaker material has been removed. Piston cores 
alone would indicate stability of the deposits in such as area.

The large-scale slumping at the transition between the upper and lower continental slope cannot be treated by the infinite slope method. The thickness of slumped material approaches the lateral scale of the slope, and shear-strength values measured in cores certainly cannot be extrapolated through the entire Pleistocene section and into the Tertiary section. As yet there have been no attempts to deal with the stability of such large thicknesses of marine sediments.

The causes of large-scale slumping must be related to Pleistocene conditions. Rapid deposition of sediment on the upper continental slope could lead to depositional oversteepening at the transition to the steeper lower continental slope, but it is not clear why this process should cause large-scale rather than small-scale slumping. Large-scale slumping may have been enhanced during the Pleistocene by the presence of aquifers at depth under the upper continental slope which were recharged with fresh water on the exposed continental shelf and which approach the surface near the transition to the lower continental 
slope. The presence of aquifers among these strata could have produced excess pore fluid pressure reducing the stability of the sediments and enhancing large-scale slumping.

Material involved in slumping has been largely removed from the continental slope. Part of the material removed was deposited at the base of the continental slope as undisturbed blocks ranging in thickness from slightly less than a meter (as seen in the piston cores on the upper continental rise) to a hundred meters or so (as seen in seismic profiles). Other deposits of slumped material appear to be thoroughly disrupted, all traces of original bedding having been destroyed. This process of disruption, taking place in the presence of water, has been shown to give rise to turbidity currents (Hampton, 1972). It is likely that the slumping of sediments on the continental slope gave rise to turbidity currents, the size of the currents related to the size of the original slump block. The evidence for turbidity currents on the continental slope remains indirect. The generating process of slumping is clearly present. Owen and Emery (1967) photographed erosional features at $1523 \mathrm{~m}$ on the lower continental slope 
in the center of the study area which they attributed to the passage of two small turbidity currents down the continental slope. V-shaped gullies incise the lower continental slope, suggesting erosion by turbidity currents. Rocks of cobble size (up to $50 \mathrm{~cm}$ ) are two to four orders of magnitude more abundant on the uppermost continental rise than on the lower continental slope a few kilometers away. These crystalline rocks are probably glacial erratics, carried to the area aboard icebergs, but there is no reason for such a sharp transition in rock abundance at the base of the continental slope if the distribution is due solely to the melting of ice. Pleistocene planktonic Foraminifera indicate cold surface waters well south of the study area (Phleger, 1942). A more likely explanation is that the cobbles were deposited more or less uniformly over the continental slope and rise, but downslope currents competent to transport material of this size have carried them to the base of the continental slope, where the decreased gradient caused their deposition. Turbidity currents are probably competent to carry cobbles on the lower continental slope (Komar, 1970); normal bottom currents probably are not. 
A gravitational process even harder to assess than turbidity currents is creep, the gradual downslope movement of sediment. In terrestrial situations, creep is almost always present in areas where slumping has taken place, is enhanced by the presence of water in the sediment, and is especially prevalent in fine-grained deposits (Carson and Kirkby, 1972). In the Pleistocene section on the continental slope these factors are optimized, suggesting that creep may indeed be an important agent of downslope transport.

From the data presented in previous chapters, it seems likely that the general shape of the continental slope has been produced at least in part by gravitational processes. This may be demonstrated by a simple model in which the amount of material moved downslope by combined gravitational processes (total mass wasting) is proportional to the gradient. This model can be applied to a variety of initial slope profiles. Culling (1963) applied the model to a situation in which two horizontal surfaces are separated by a vertical step. A convexity works back into the upper plateau, and a concavity spreads out across the lower surface. The final form of such a model is 
almost identical to the general form of the profiles across the continental slope, suggesting that gravitational processes for which the rate of transport is controlled by the slope of the bottom may have been dominant in forming the general shape of the continental slope. HYDRODYNAMIC PROCESSES

Currents moving over the sediment surface have modified the bottom throughout the study area. The effects of moving water are most pronounced near the shelf-break and on the upper continental rise.

Near the shelf-break scour marks on the bottom, coarse-grained surface deposits, abundant suspended sediment, and well-mixed bottom waters (Parke, 1972) indicate active bottom currents. High current velocities near the bottom may be due to sinking of waters made dense during the winter months by cooling and evaporation (termed cascading by Cooper and Vaux, 1949) and shoaling internal waves (Cacchione, 1970) or by some other process. The observations indicating active bottom waters were made in the summer and fall, and may indicate bottom erosion by shoaling internal waves. 
Cacchione (1970) has shown that amplification of nearbottom current velocities beneath internal waves with realistic periods and amplitudes can cause incipient motion of the sediments on the upper portions of the continental slope in the study area. Breaking of internal waves on the upper continental slope would produce turbulent conditions and high current velocities near the bottom, and would produce a layer of homogeneous density near the bottom by mixing. Cacchione's experiments suggest that where breaking occurs well-sorted and coarse sediment relative to nearby material should be found. Southard and Cacchione (1972) extended the laboratory modeling to include sediment transport, and found that sediment movement due to breaking internal waves occurs over a band much larger than the wave amplitude, and that the predominant movement is downslope, except near the breaking point, where movement is upslope.

These observations fit well with the observed sediment distribution near the shelf-break. Shoaling and breaking internal waves seem to be the most likely agent to account for the well-mixed bottom waters, high concentrations of suspended sediment, erosion of the bottom, 
and coarse surface sediments observed in this study near the shelf-break. Furthermore, the active downslope transport of sand-sized material suggested by the results of Southard and Cacchione (1972) may account for the abundant sand-sized material in the Holocene sediments of the upper continental slope.

The low concentrations of suspended sediment and the clarity of near-bottom waters observed in bottom photographs on the lower continental slope indicate that little of the fine-grained material in suspension on the outer continental shelf was being transported downslope at the times of observation. Residual currents measured directly in the study area are toward the southwest (Wunsch and Hendry, 1972). Measurements of temperature and salinity on the outer continental shelf and upper continental slope (Wright, 1972) indicate geostrophic currents of about $1 / 2$ knot in a westward direction. The long-term direction of transport in suspension is thus predominantly along the continental margin, with a small downslope component. The sinking of dense shelf waters during the winter months might increase the net downslope transport, at least over the upper continental slope, but observations of the 
temperature and salinity of continental shelf and upper continental slope waters near (and within) the study area during the winter and early spring months. (Ketchum and Corwin, 1964; Wright, 1972) indicate stability of the water column on the outer shelf and upper slope. Even in the most favorable season, water on the outer continental shelf would freeze before it would be cooled to a density to sink below the shelf break. The salinity gradient across the boundary between shelf and slope waters in this area is much too strong to be counteracted by cooling of the shelf waters.

On the deeper portions of the continental slope, bottom currents have little apparent influence on the sediment surface. The flume experiments of this study and in-situ observations (this study; Emery and Ross, 1968) indicate that even very high current velocities (over $70 \mathrm{~cm} / \mathrm{sec} 3$ meters from the bottom) are unable to erode the sediment surface, and short-term deposition from bottom waters is not sufficient to produce features such as depositional lee-ridges behind obstacles.

Smoothing of the bottom observed in DSRV ALVIN tracks and in bottom photographs may be in part due to bottom 
currents, but the evidence is inconclusive. Flume runs indicate that smoothing takes place at low to moderate bottom current velocities by preferential deposition in low spots in the resedimented bed (Table 2), and observations from ALVIN indicate that light flocculent material is available at the surface to produce smoothing.

On the upper continental rise, scour marks and other current markings are abundant, probably due to the softness of the surface sediments, since bottom-current velocities are similar to or slightly lower than those of the continental slope (Wunsch and Hendry, 1972). Sediment deposited at the base of the continental slope is thus apparently subject to reworking by bottom currents. It seems likely that the resuspension of continental-rise material by moderate bottom currents supplies much of the material suspended in the nepheloid layer of the western North Atlantic Basin. BIOLOGICAL PROCESSES

The benthic fauna of the continental slope is an active sedimentary agent in the study area. The effects of bottom organisms vary according to the nature of the bottom and the habits of the organisms in any given locality. 
In some areas, especially on the lower continental slope, indurated sediments are exposed at the surface. These outcrops were presumably exposed by slumping, and their surfaces have been subject to modification by animals. Dillon and zimmerman (1970) and Warme and others (1971) have discussed the erosional activity of burrowing organisms in submarine canyons by which rock fragments are loosened from outcrops. Photographs of rock outcrops and direct observation from submersible show extensive talus slopes beneath vertical rock outcrops which can probably be attributed at least in part to this mechanism.

Small scale slumping of partly indurated sediments on land tends to leave a sharply defined scar, with little fragmented material at the base of the failure scarp. If a similar form is produced on the continental slope, then the formation of talus slopes would be a post-failure process. The size of talus slopes at the base of slump scarps might be a valuable index of the age of the slump scar. Observations from ALCOA SEAPROBE indicated wide variation in the size of talus slopes, but the data were insufficient to apply quantitatively. 
Most of the continental slope is mantled by unconsolidated sediments. The biological effects of the benthic fauna on unconsolidated material are primarily caused by movement over the surface by the epibenthic fauna, and by activity within the sediment by the infauna.

Movement of epibenthic invertebrates over the sediment surface produces tracks and trails, increasing the smallscale roughness of the sediment surface. It is well known that bed irregularities increase the capacity of bottom currents to erode cohesive sediments (see for example, Allen, 1969). The flume experiments using sediments from the study area suggest that mass erosion at such irregularities may be the dominant mode of bottom current erosion on the lower continental slope, if in fact bottom currents are capable of eroding the bottom at all. Suspension of bottom sediments by movements of the invertebrate epifauna was not observed from ALVIN, nor in bottom photographs, but the movements of fish near the bottom were observed to stir material into suspension.

A second major effect of the epifauna may be to smooth the sediment surface. This process is not incompatible with the roughening process just discussed. Although the epibenthic fauna may produce roughness (tracks and trails) 
on the order of a $\mathrm{cm}$ or so, they may well destroy roughness elements of larger size. In the zone on the lower continental slope in which macroscopic epibenthic invertebrates are scarce $(800-1500 \mathrm{~m})$ the surface tends to be rougher on a scale of several $\mathrm{cm}$ and large burrows and excavations are better defined than on portions of the continental slope where the epibenthic population is numerous. Brittle stars on the lower continental slope were immediately attracted to holes in the sediment produced by box-coring, and crawled into them, perhaps taking advantage of the fresh sediment surface for feeding. Such activity could smooth the irregularity and produce a small, ill-defined depression in a short period. Sharply defined tracks made by ALVIN are markedly degraded and smoothed in the course of a year. The tracks produced by the epifauna may be smoothed in turn by the infauna. Cullen (1973) has demonstrated that small $(\leq 1 \mathrm{~mm})$ organisms within the sediment can obliterate tracks made in mud by epibenthic organisms within the span of 10-14 days by locomotive and feeding activity. This type of activity may help explain the scarcity of tracks in bottom photographs, except those 
which appear to be made very recently, often by animals in the photographs.

Reworking of bottom sediments by the infauna is likely to be confined largely to the upper few $\mathrm{cm}$ of sediment (Rhoads, 1967; Griggs and others, 1969). Random displacements of sediment particles by the infauna under conditions of slow deposition during the Holocene may have produced the reverse grading observed in the upper $8 \mathrm{~cm}$ of sediments from the lower continental slope. The surprising resistance of continental slope sediments to erosion by bottom currents also may be caused by the infauna. While cullen (1973) found that ostracodes and copepods tended to disrupt and smooth the sediment surface, small annelids rapidly establish an intricate, closely spaced network of threadlike burrows, which persisted for several hours until it was disrupted by the activity of other organisms. These burrows could produce sediment reinforcement. The fibrous binding material observed on broken surfaces in the flume runs probably has such an origin.

Sampling of the infauna on the continental slope in the study area (Sanders and others, 1965) indicates that 
polycheate worms comprise $65-70 \%$ of the infauna, in abundances from 1000-16,000 individuals per $\mathrm{m}^{2}$. The remaining $30-35 \%$ of the infauna are mostly crustacea and pelycypoda, which would counteract the binding process by distruption. It appears from the sampling that the infauna present could produce both small-scale smoothing of the surface by disruption of the surface sediments and reinforcement of the sediment surface.

NET EFFECTS OF SEDIMENTARY PROCESSES DURING THE PLEISTOCENE AND HOLOCENE

The Pleistocene and Holocene have been periods of widely varying conditions on the continental slope. Pleistocene deposits include detrital sands, planktonic Foraminiferal sands, silts, and clays, reflecting marked variations in the amounts and types of material available from source areas. The record is incomplete and disrupted by removal and displacement of slope deposits, but a partial understanding of the response of bottom sediments to a changing environment can be obtained from the data presented in this report pertaining to the transition from late Pleistocene glacial to Holocene interglacial conditions. 
During the late Pleistocene, the shoreline was near the shelf break, and continental glaciation inland produced abundant fine-grained material which was carried to the sea as suspended load to be deposited in large quantities on the continental slope and further offshore. The lower continental slope, because of its steep gradient, underwent continuous creep, small-scale slumping, and possibly turbidity-current erosion, resulting in severely limited net accumulation. The upper continental slope, with a more gentle gradient, accumulated large thicknesses of sediment. At the transition between upper and lower continental slope, large-scale slumping resulted from depositional oversteepening and perhaps spring sapping. The continental rise and abyssal plains received vast amounts of sediments, from direct transport of fine material, from turbidity currents carrying sand and larger material down submarine canyons from the shelf break, and from slumping and resultant turbidity currents from the continental slope. On the uppermost continental rise between submarine canyons (such as the deepest portions of the study area) the principal pleistocene deposits are slumped material, pelagic foraminifera, and cobbles transported by ice rafting and possibly turbidity currents. 
Slumping in the Pleistocene exposed older, more consolidated deposits of Tertiary and Upper cretaceous age, and provided a local source for the fragments of sedimentary rocks, glauconite, early Tertiary foraminifera, kaolinite, and pyrite, which are found reworked into younger deposits, perhaps by active burrowing by the benthic fauna.

Thus, the glacial periods of the Pleistocene were periods of rapid deposition and mass downslope movement. Thick accumulations of sediment occurred on the gently sloping upper continental slope and continental rise, but gravitational processes allowed only a thin deposit on the steeper lower continental slope. As sea level rose, the supply of fine material was abruptly reduced. Deposition of fine-grained sediment apparently shifted its position, and followed the transgressing shoreline, mantling the transgressive sand on the outer continental shelf of this area with a layer of clayey silt. Deposition on the continental slope slowed to a fraction of Pleistocene rates. In response to these changes, different processes became dominant on the continental slope. Although slumping probably continued, due to the 
presence of metastable deposits, slumps became less frequent. Bottom currents became more important, especially at the shelf break, where they reworked surface sediments, transported sand onto the upper continental slope, and transported fine material along the margin and perhaps downslope. On the lower continental slope, organisms reworked the thin Pleistocene deposits, possibly causing considerable net downslope movement, but rendering the sediment highly resistant to erosion by bottom currents. on the continental rise, rapidly deposited pleistocene deposits were reworked, resuspended, and redeposited by organisms and bottom currents to form a Holocene deposit of a meter or so in thickness with a character essentially similar to Pleistocene sediments, but with an added component of warm water planktonic Foraminifera and an increased proportion of montmorillonite in the clay fraction.

Thus, the Holocene has been a period of reworking of Pleistocene deposits, and bottom currents and biological activity have become the dominant sedimentary processes on the continental slope. 
EARLY PLEISTOCENE AND PRE-PLEISTOCENE CONDITIONS

The conditions on the continental slope in earlyand pre-Pleistocene times are difficult to determine. Aside from the Pleistocene material obtained in cores and from one outcrop sampled by ALVIN, no sediments between Eocene and Holocene age have been recovered from the study area.

Upper Cretaceous sediment in the study area have been recovered from only one location in Alvin Canyon. The Upper Cretaceous sample (Gibson, Hazel, and Mello, 1968) is a silt-stone, similar in texture to the finergrained Pleistocene deposits. It indicates a period of rapid detrital deposition, probably accompanied by mass downslope movement. Seismic profiles indicate that deeper reflectors, perhaps Upper cretaceous in age, have a configuration similar to the present surface, with an upbuilt upper continental slope and a steep lower continental slope. Rapid deposition and mass downslope movement must have started about this time, since Horizon A appears to lie beneath the bulk of continental rise deposits. Eocene deposits have been recovered near the transition between upper and lower continental slope at two 
locations within the study area (Stetson, 1949; Northrup and Heezen, 1951). Both samples consist of planktonic Foraminifera, with very low detrital content. These samples indicate a period of very slow accumulation, but the fact that they are the only Tertiary samples recovered from the study area suggests that biogenic sediments slowly accumulated may be the most stable and stand the best chance for preservation.

Pleistocene deposits observed in the cores from the upper continental rise suggest the variability of Pleistocene continental-slope deposits, since they were displaced from upslope and probably represent wide ranges of time and conditions of deposition. Foraminiferal oozes, similar to Eocene material, indicate periods of very slow accumulation, while detrital layers probably represent periods of rapid accumulation. The peculiarity of the Pleistocene is probably the rapidity of changes between glacial periods of rapid deposition and interglacial periods of relatively slow deposition. 
CHAPTER V

SUMMARY AND CONCLUSIONS

The most important results of this study concern the processes which control transportation, deposition, and erosion of continental slope sediments, and the factors which enhance or reduce the effectiveness of each process. Gravitational processes are the dominant erosional agents on the continental slope in this area. The downslope movement of sediment by gravitational processes is enhanced by increased sediment supply and rapid deposition during glacial periods. The steepness of the bottom controls the amount of material which can be deposited without failure. Only a few meters of rapid deposition is stable on the steep lower continental slope. Especially large slumps occur at the increase in gradient from the upper continental slope to lower continental slope. Turbidity currents generated by slumping have apparently eroded gullies and swept the bottom clear of glacial erratics on the steep lower continental slope.

Hydrodynamic processes are most influential near the shelf break, where they probably control the deposition and transport of sediments. Internal waves may generate strong bottom currents and turbulence, winnowing the finer material 
and suspending fine-grained material. Some downslope movement of sand over the upper continental slope has taken place during the Holocene. Persistant westward currents along the margin transport fine material parallel to the isobaths, and little of this suspended material presently reaches the base of the continental slope by direct downslope flow of water over the open continental slope. Most of the surface of the continental slope is extremely resistant to erosion by bottom currents. The surface of the upper continental rise is modified by erosion and deposition from bottom flows.

Biological activity is zoned according to depth, since the species composition of the benthic fauna varies down the continental slope. The overall effects of the fauna are difficult to quantify, but are undoubtedly significant. Bottom organisms smooth irregularities in the bottom over a period of years, stiffen the sediment surface, rendering it resistant to erosion by bottom currents, and may cause significant net downslope movement of sediment by small excavations and displacements.

Rapid variations during the Pleistocene of the amount of material entering the study area have caused changes in 
the sedimentary environment. During glacial periods of rapid deposition, equilibrium is established predominantly on the basis of bottom incline and gravitational processes. During interglacial periods of slow deposition, hydrodynamic and biological processes tend to dominate.

A final important finding of this study is the demonstration that a detailed study of a small area of sea floor utilizing a wide variety of techniques and approaches can produce an understanding of the total sedimentary environment. While the detail available in marine surveys of this type do not yet approach the detail in terrestrial studies (limiting quantitative interpretation), this study contains much more detail than most marine surveys. This concentration of information allows interpretation which is impossible on the basis of large-scale regional studies. 


\section{$-201-$ \\ REFERENCES}

Allen, J. R. L., 1969, Erosional current marks of weakly cohesive mud beds: Jour. Sediment. Petrol., v. 39, p. $607-623$.

Barnard, W. D., and D. A. McManus, 1973, Planktonic foraminiferan-radiolarian stratigraphy and the Pleistocene - Holocene boundary in the Northeast Pacific: Geol. Soc. America Bull., v. 84, p. 20972100.

Biscaye, Pierre, 1965, Mineralogy and sedimentation of recent deep-sea clay in the Atlantic ocean and adjacent seas and oceans: Geol. Soc. America Bull., v. 76, p. 803-832.

Cacchione, D. A., 1970, Experimental study of internal waves on a slope: $\mathrm{Ph} . \mathrm{D}$. Thesis, Massachusetts Institute of Technology and Woods Hole Oceanographic Institution, $226 \mathrm{p}$.

Carson, M.A., and M. J. Kirkby, 1972, Hillslope form' and process: Cambridge at the University Press, 475 p. Cooper, L. H. N., and D. Vaux, 1949, Cascading over the continental slope of water from the celtic sea: Jour. Marine Biol. Assoc. U.K., v. 28, p. 719-750. 
Cullen, D. J., 1973, Bioturbation of superficial marine sediments by interstitial meiobenthos: Nature, v. 242, p. $323-324$.

Culling, W. E. H., 1963, Soil creep and the development of hills; de slopes: Jour. Geol., v. 71, p. 127-161. Dillon, William P. and Herman B. Zimmerman, 1970, Erosion by biological activity in two New England submarine canyons: Jour. Sediment. Petrol., v. 40, p. 542-547. Drake, C. L., J. I. Ewing, and H. Stockard, 1968, The continental margin of the eastern United States: Canadian Jour. Earth. Sci., v. 5, p. 993-1010.

Eittreim, S., M. Ewing, and E. M. Thorndike, 1969, Suspended matter along the continental margin of the North American Basin: Deep-Sea Res., v. 16, p. 613-624. Emery, K. O., and D. A. Ross, 1968, Topography and sediments of a small area of the continental slope south of Martha's Vineyard: Deep-Sea Res., v. 15, p. 415-422. Emery, K. O., and Elazar Uchupi, 1972, Western North Atlantic Ocean: Topography, rocks, structure, water, 1 ife, and sediments: Amer. Assoc. Petroleum Geologists Memoir, 17, 532 p. 
Emery, K. O., Elazar Uchupi, J. D. Phillips, C. O. Bowin, E. T. Bunce, and S. T. Knott, 1970, Continental rise of eastern North America: Amer. Assoc. Petroleum Geologists Bull., v. 54, p. 44-108.

Emiliani, C., 1971, The last interglacial: Paleotemperatures and chronology: Science, v. 171, p. 571-573.

Ericson, D. B., M. Ewing, Goesta Wollin, and B. C. Heezen, 1961, Atlantic deep-sea sediment cores: Geol. Soc. America Bull., v. 72, p. 193-286. Ewing, John, Xavier Le Pichon, and M. Ewing, 1963, Upper stratification of Hudson Apron region: Jour. Geophys. Res., v. 68, p. 6303-6316.

Ewing, M., J. L. Worzel, A. O. Beall, W. A. Berggren, D. Bukry, C. A. Burk, A. G. Fischer, and E. A. Pessagno, Jr., 1969, Initial reports of the Deep Sea Drilling Project, v. 1: National Sci. Foundation, 672 p. Garrison, L. E., and R. L. McMaster, 1966, Sediments and geomorphology of the continental shelf off southern New England: Marine Geol., v. 4, p. 273-289. Gibson, T. G., J. E. Hazel, and J. F. Mello, 1968, Fossiliferous rocks from submarine canyons off the northeastern U. S.: USGS Prof. Paper 600-D, p. 222231. 
Griggs, G. B., A. G. Carey, and L. D. Kulm, 1969, Deep-sea sedimentation and sediment-fauna interaction in Cascadia Channel and on Cascadia Abyssal Plain: Deep-Sea Res., v. 16, p. 157-170.

Hampton, M. A., 1972, The role of subaqueous debris flow in generating turbidity currents: Jour. Sediment. Petrol., v. 42, p. 775-794.

Hayes, J. R., and M. A. Klugman, 1959, Feldspar staining methods: Jour. Sediment. Petrol., v. 29, p. 227232.

Heezen, B. C., M. Tharp, and M. Ewing, 1959, The floors of the oceans, I, The North Atlantic: Geol. Soc. America Special Paper, 65, 122 p. Hoskins, H., 1967, Seismic reflection observations on the Atlantic continental shelf, slope, and rise southeast of New England: Jour. Geol., v. 75, p. 598-611. Jacobs, M. D., and M. Ewing, 1969, Suspended particulate matter: Concentrations in the major oceans: Science, v. 163, p. 380-383.

Ketchum, B., and N. Corwin, 1964, The persistance of "winter" water on the continental shelf of Long Island, New York: Limnology and Oceanography, v. 9, p. $467-475$. 
Knott, S. T., 1970, Operational technique for continuous seismic profiling and related studies: Woods Hole Oceanographic Institution, Ref. No. 70-43. Unpublished manuscript.

Knott, S. T., and H. Hoskins, 1968, Evidence of Pleistocene events in the structure of the continental shelf off northeastern United States: Marine Geol., v. 6, p. $5-43$.

Komar, P. D., 1970, The competence of turbidity current flow: Geol. Soc. America Bull., v. 81, p. 1555-1562. Lyall, A. K., D. J. Stanley, H. N. Giles, and A. Fisher, Jr., 1971, Suspended sediment and transport at the shelforeak on the slope-Wilmington Canyon area, Eastern U. S. A.: Jour. Marine Technol. Soc., v. 5, p. 15-21.

MacIlvaine, J. C. and D. A. Ross, 1973, Surface sediments of the Gulf of Panama: Jour. Sediment. Petrol.., v. 43, p. 215-223.

Manheim, F. T., R. H. Meade, and G. C. Bond, 1970, Suspended matter in surface waters of the Atlantic continental margin from cape cod to the Florida Keys: Science, v. 167, p. 371-376. 
Matthews, D. H., 1939, Tables of the velocity of sound in pure water and sea water: London, Admiralty Hydrog. Dept., 32 p.

McMaster, U. L., and Garrison, L. E., 1966, Mineralogy and origin of southern New England shelf sediments: Jour. Sediment. Petrol., v. 36, p. 1131-1142.

Menard, H. W., and S. M. Smith, 1966, Hypsametry of ocean basin provinces: Jour. Sediment. Petrol., v. 71, p. $4305-4325$.

Milliman, J. D., O. H. Pilkey, and D. A. Ross, 1972, Sediments of the continental margin off the eastern United States: Geol. Soc. America Bull., v. 83, p. 1315-1334.

Moore, D. G., 1961, Submarine slumps: Jour. Sediment. Petrol., v. 31, p. 343-357.

Morelock, J., 1969, Shear strength and stability of continental slope deposits, western Gulf of Mexico: Jour. Geophys. Res., v. 74, p. 465-482.

Murray, G. E., 1961, Geology of the Atlantic and Gulf Coast province of North America: New York, Harper and Brothers, $692 \mathrm{p}$. 
Northrop, John, and B. C. Heezen, 1951, An outcrop of Eocene sediment on the continental slope: Jour. Geol., v. 59, p. 396-399.

Owen, D. M., and K. O. Emery, 1967, Current markings on the continental slope: IN Deep-Sea Photography, J. B. Hersey, ed., Johns Hopkins Oceanographic Study, No. 3, p. 167-172.

Parke,M. E., 1972, A bottom homogeneous layer near the shelf margin south of Cape Cod: Unpublished manuscript of the Woods Hole Oceanographic Institution. Phleger, F. B., 1939, Foraminifera of submarine cores from the continental slope: Geol. Soc. America Bull., v. 50, p. 1395-1422.

Phleger, F. B., 1942, Foraminifera of submarine cores from the continental slope, part 2: Geol. Soc. America Bull., v. 53, p. 1073-1098. Rhoads, D. C., 1967, Biogenic reworking of intertidal and subtidal sediments in Barnstable Harbor and Buzzards Bay, Massachusetts: Jour. Geol., v. 75, p. $461-476$.

Ross, D. A., 1971, Mass physical properties and slope stability of sediments of the northern Middle America Trench: Jour. Geophys. Res., v. 76, p. 704-712. 
Rowe, G. T. and C. H. Clifford, 1973, Modifications of the Birge-Ekman box corer for use with SCUBA or Deep Submergence Research Vessels, in press.

Rowe, G. T., G. Keller, H. Edgerton, N. Staresinic, and J. MacIlvaine; in press, Time-lapse photography of the biological reworking of sediments in Hudson Canyon, in press.

Sanders, H. L., R. R. Hessler, and G. R. Hampton, 1965, An introduction to the deep-sea faunal assemblages along the Gay Head-Bermuda transect: Deep-Sea Res., v. 12, p. 845-867.

Shepard, F. P., 1954, Nomenclature based on sand-siltclay ratios: Jour. Sediment. Petrol., v. 24, p. 151-158.

Southard, J. B., and D. A. Caccione, 1972, Experiments on bottom sediment movement by breaking internal waves: IN Shelf Sediment Transport: Process and Pattern, D. J. P. Swift, D. B. Duane, and O. H. Pilkey, eds., Dowden, Hutchinson, and Ross, Inc.. $656 \mathrm{p}$.

Southard, J. B., R. A. Young, and C. D. Hollister, 1971, Experimental erosion of fine abyssal sediment: Jour. Geophys. Res., v. 76, p. 5903-5909. 
Sternberg, R. W., 1970, Field measurements of the hydrodynamic roughness of the deep-sea boundary: DeepSea Res., v. 17, p. 413-420.

Stetson, H. C., 1936, Geology and paleontology of the Georges Bank canyons: Part I, Geology: Geol. Soc. America Bull., v. 47, p. 339-366.

Stetson, H. C., 1949, The sediments and stratigraphy of the east coast continental margin-Georges Bank to Norfolk Canyon: M.I.T. and W.H.O.I. papers in Phys. Oc. and Met., v. 11, (2), p. 1-60.

Taylor, D. W., 1948, Fundamentals of Soil Mechanics, John Wiley, New York, 700 p.

Trumbull, J. V. A., 1972, Atlantic continental shelf and slope of the United States - Sand size fraction of bottom sediments, New Jersey to Nova Scotia: U. S. Geol. Survey. Prof. Paper 529.

Twenhofel, W. H., and S. A. Tyler, 1941, Methods of study of sediments: McGraw-Hill, New York, 183 p.

Uchupi, E., 1967, Slumping on the continental margin southeast of Long Island: Deep-Sea Res., v. 14, p. 635-638. Uchupi, E., and K. O. Emery, 1967, Structure of continental margin off the Atlantic coast of the U. S.: Amer. Assoc. Petroleum Geologists Bull., v. 51, p. 223-234. 
Warme, J. E., T. B. Scanland, and N. F. Marshall, 1971, Submarine canyon erosion: Contribution of marine rock burrowers: Science, v. 173, p. 1127-1129. Wright, W. R., 1972, Currents at the edge of the continental shelf south of Cape Cod: Proposal to the National Science Foundation, unpublished manuscript. Wunsch, Carl, and Ross Hendry, 1972, Array measurements of the bottom boundary layer and the internal wave field on the continental slope: Geophys. Fluid Dynamics, v. 4, p. 101-145. 
BIOGRAPHY

Birth: May 8, 1947

Education:

1965-1967 University of California, San Diego, California

1967-1969 University of California, Berkeley, California

1969 B.A., in Geology with honors, University of California, Berkeley, California

1969-1973 Research Fellow at the Woods Hole Oceanographic Institution, Woods Hole, Massachusetts

Publications:

MacIlvaine, Joseph, and D.A. Ross, 1973, Surface sediments of the Gulf of Panama: Jour. Sediment. Petrol., v. 43, pp. 215-223.

Ross, D.A., E. Uchupi, K. Prada, and J. MacIlvaine In press, Bathymetry and microtopography of the Black Sea: In Degens and Ross, eds., The Black Sea: Geology, Chemistry and Biology: American Assoc. Petrol. Geologists, Memoir 20.

MacIlvaine, J., 1971, The effect of sedimentation on primary production in the wet lands: Papers on National Land Use Policy Issues: U.S. Govt. Printing Office, Publ. 57-242, pp. 177-189.

Ross, D.A., E.T. Degens, and J. MacIlvaine, 1970, Black Sea: Recent sedimentary history: Science, v. 170, pp. 163-165.

Ross, D.A., E.T. Degens, J. MacIlvaine, and R.M. Hedberg, 1970, Recent sediments of the Black Sea: Oceanus, v. 15, pp. 26-29. 


\section{MANDATORY DISTRIBUTION LIST \\ FOR UNCLASSIFIED TECHNICAL REPORTS, REPRINTS, \& FINAL REPORTS \\ PUBLISHED BY OCEANOGRAPHIC CONTRACTORS \\ OF THE OCEAN SCIENCE \& TECHNOLOGY DIVISION \\ OF THE OFFICE OF NAVAL RESEARCH}

(REVISED SEPT. 1973)

1 Director of Defense Research and Engineering

Office of the Secretary of Defense

Washington, D。C。 20301

ATTN: Office, Assistant Director

(Research)

12 Defense Documentation Center

Cameron Station

Alexandria, Virginia 22314

Office of Naval Research

Department of the Navy

Arlington, Virginia 22217

3 ATTN: Ocean Science \& Technology

Division, Code 480

1 ATTN: Naval Applications \& Analysis

Division, Code 460

1 ATTN: Code 102-OS

1 Office of Naval Research

Branch Office

495 Summer Street

Boston, Massachusetts 02210

1 LCDR David Cacchione, (USN)

ONR Representative

Woods Hole Oceanographic Institution

Woods Hole, Massachusetts 02543

Director

Naval Research Laboratory

Washington, D。C 20390

6 ATTN: Library, Code 2029 (ONRL)

6 ATTN: Library, Code 2620
Commander

Naval Oceanographic Office

Washingt on, D。C。 20390

1 ATTN: Code 1640 (Libraxy)

1. ATTN: Code 70

1 Director

National Oceanographic Data Center

National Oceanic \& Atmospheric Administration

B1dg。 160

Washington Navy Yard

Rockville, Maryland 

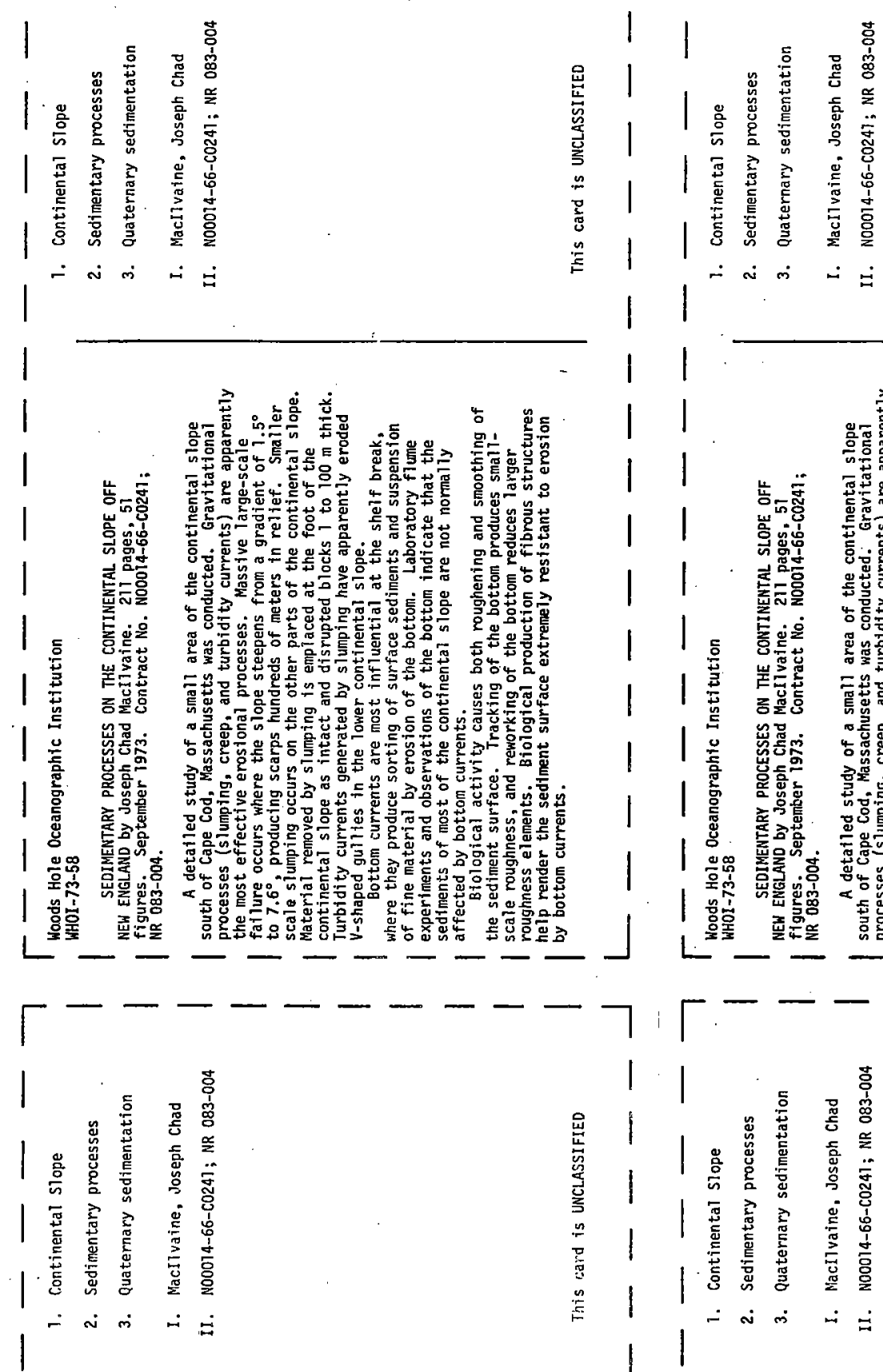

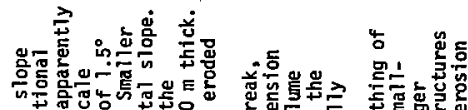

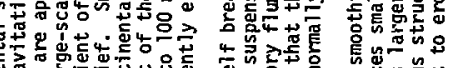

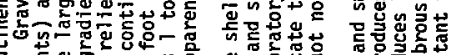

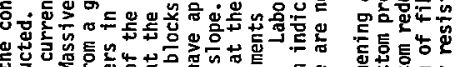

等

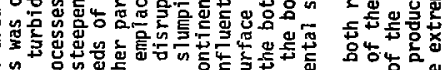

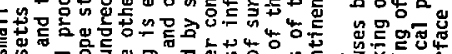

管

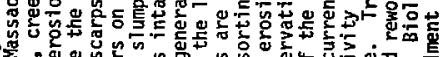

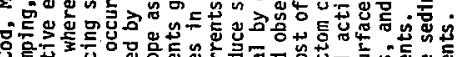

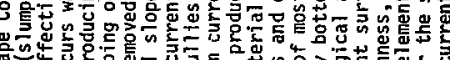

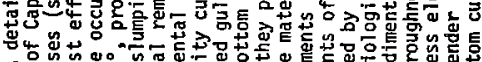

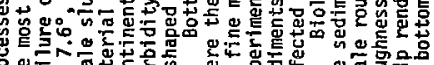

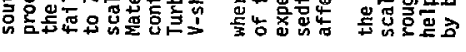

$\therefore$ ल में 
SECURITY CLASSIFICATION OF THIS PAGE (Whon Data Entered)

\begin{tabular}{|c|c|c|}
\hline \multicolumn{2}{|c|}{ REPORT DOCUMENTATION PAGE } & \multirow{2}{*}{$\begin{array}{l}\text { READ INSTRUCTIONS } \\
\text { BEFORE COMPLETING FORM } \\
\text { 3. RECIPIENT'S CATALOG NUMBER }\end{array}$} \\
\hline $\begin{array}{l}\text { 1. REPORT NUMBER } \\
\text { WHOI-73-58 }\end{array}$ & 2. GOVT ACCESSION NO. & \\
\hline \multicolumn{2}{|c|}{$\begin{array}{l}\text { 4. TITLE (and Subttile) } \\
\text { SEDIMENTARY PROCESSES ON THE CONTINENTAL SLOPE } \\
\text { OFF NEW ENGLAND }\end{array}$} & $\begin{array}{l}\text { 5. TYPE OF REPORT A PERIOD COVERED } \\
\text { Technical } \\
\text { 6. PERFORMING ORG. REPORT NUMBEF }\end{array}$ \\
\hline \multicolumn{2}{|l|}{$\begin{array}{l}\text { 7. AUTHOR(s) } \\
\text { Joseph Chad MacIlvaine }\end{array}$} & $\begin{array}{l}\text { 8. CONTRACT OR GRANT NUMEER(A) } \\
\text { N00014-66-C0241 }\end{array}$ \\
\hline \multicolumn{2}{|c|}{$\begin{array}{l}\text { 9. PERFORMING ORGANIZATION NAME AND ADDRESS } \\
\text { Woods Hole Oceanographic Institution } \\
\text { Woods Hole, Massachusetts } 02543\end{array}$} & $\begin{array}{l}\text { 10. PROGRAM ELEMENT. PROJECT, TASK } \\
\text { AREA WORK WNIT NUMBERS TAR } \\
\text { NR } 083-004\end{array}$ \\
\hline \multicolumn{2}{|l|}{$\begin{array}{l}\text { 11. CONTROLLING OFFICE NAME AND ADDRESS } \\
\text { Office of Naval Research } \\
\text { Code } 480\end{array}$} & $\begin{array}{l}\text { 12. REPORT DATE } \\
\text { September } 1973 \\
\text { 13. NUMEER OF PAGES } \\
211\end{array}$ \\
\hline \multicolumn{2}{|c|}{ 14. MONITORING AGENCY NAME \& ADORESS(it different from Conerooltine Ofllcos) } & $\begin{array}{l}\text { 15. SECURITY CLASS. (of thia roport) } \\
\text { UnClassified } \\
\text { 15. OECLLASSIFICATION/DOWNGRADING } \\
\text { SEHEOULE }\end{array}$ \\
\hline \multicolumn{3}{|c|}{$\begin{array}{l}\text { 16. OISTRIBUTION STATEMENT (oo thls Ropori) } \\
\text { Approved for public release; distribution unlimited. }\end{array}$} \\
\hline
\end{tabular}

18. SUPPLEMENTARY NOTES

Submitted in partial fulfillment of the requirements for the degree of Doctor of Philosophy at the Massachusetts Institute of Technology and the Woods Hole Oceanographic Institution.

19. KEY WORDS (Continue on reverse side if nocessary and identlfy by block number)

1. Continental Slope

2. Sedimentary processes

3. Quaternary sedimentation

20. ABSTRACT (Contlnue on reverse alde if neceseary and identity by block number)

A detailed study of a small area of the continental slope south of Cape Cod, Massachusetts was conducted. Gravitational processes (slumping, creep, and turbidity currents) are apparently the most effective erosional processes. Massive large-scale failure occurs where the slope steepens from a gradient of $1.5^{\circ}$ to $7.6^{\circ}$, producing scarps hundreds of meters in relief. Smaller scale slumping occurs on the other parts of the continental slope. Material removed by slumping is emplaced at the foot of the continental slope as intact and

DD, FORM 1473 EDITION OF I NOV 65 IS OBSOLETE

$\mathrm{S} / \mathrm{N} 0102 \cdot 014-6601$

$$
\text { UNCLASSIFIED } \quad 9 / 25 / 73
$$

SECURITY CLASSIFICATION OF THIS PAGE (When Date Enered) 
20. disrupted blocks 1 to $100 \mathrm{~m}$ thick. Turbidity currents generated by slumping have apparently eroded V-shaped gullies in the lower continental slope.

Bottom currents are most influential at the shelf break, where they produce sorting of surface sediments and suspension of fine material by erosion of the bottom. Laboratory flume experiments and observations of the bottom indicate that the sediments of most of the continental slope are not normally affected by bottom currents.

Biological activity causes both roughening and smoothing of the sediment surface. Tracking of the bottom produces small-scale roughness, and reworking of the bottom reduces larger roughness elements. Biologica production of fibrous structures help render the sediment surface extremely resistant to erosion by bottom currents. 